\title{
The controversial role of mast cells in fibrosis
}

\section{Peter Bradding ${ }^{1}$ and Gunnar Pejler ${ }^{2,3}$}

${ }^{1}$ University of Leicester, Department of Infection, Immunity and Inflammation, Institute for Lung Health, Leicester United Kingdom

${ }^{2}$ Uppsala University, Department of Medical Biochemistry and Microbiology, Uppsala, Sweden

${ }^{3}$ Swedish University of Agricultural Sciences, Department of Anatomy, Physiology and Biochemistry, Uppsala, Sweden

Correspondence to: Peter Bradding, Department of Infection, Immunity and Inflammation, Institute for Lung Health, University of Leicester, Leicester LE3 9QP, United Kingdom; pb46@le.ac.uk or Gunnar Pejler, Uppsala University, Department of Medical Biochemistry and Microbiology, BMC Box 882, 75123 Uppsala, Sweden; gunnar.pejler@imbim.uu.se 


\begin{abstract}
Fibrosis is a medical condition characterized by an excessive deposition of extracellular matrix compounds such as collagen in tissues. Fibrotic lesions are present in many diseases and can affect all organs, and are also present in many cancers. The excessive extracellular matrix accumulation in these conditions can often have serious consequences and in many cases be life-threatening. A typical event seen in many fibrotic conditions is a profound accumulation of mast cells (MC), suggesting that these cells can contribute to the pathology. Indeed, there is now substantial evidence pointing to an important role of MCs in fibrotic disease. However, investigations based on various clinical settings and different animal models have arrived at partly contradictory conclusions as to how MCs affect fibrosis, with many studies suggesting a detrimental role of MCs whereas others suggest that MCs can be protective. Here we review the current knowledge of how MCs can affect fibrosis.
\end{abstract}

Key words: mast cell, fibrosis, lung, kidney, heart, skin, liver

Running title: Mast cells in fibrosis 
LIST OF CONTENTS

Abstract

Introduction

Mast cell in lung fibrosis

- Mast cells infiltrate human fibrotic lung tissue

- Mast cell activation in human fibrotic lung tissue

- Mast cell phenotype in human lung fibrosis

Mast cells in human chronic kidney disease

Mast cells in human systemic sclerosis

Mast cells in human cardiac fibrosis

Mast cells in human liver fibrosis

Human mast cell-fibroblast cross-talk in the pathogenesis of fibrosis

- Mast cell mediators acting on human fibroblasts

- Bi-directional human mast cell-fibroblast cross-talk in co-culture

The importance of mast cell-fibroblast adhesion mediated via CADM1

Approaches to studying mast cell function in animal models

Mast cells in models of lung fibrosis

Mast cells in models kidney fibrosis

Mast cells in models of skin fibrosis

Mast cells in models of cardiac fibrosis

Mast cells in models of liver fibrosis

Mast cells in models of lymph node fibrosis

Mast cells in models of adipose tissue fibrosis

Mast cell proteases in models of fibrosis

Targeting mast cell in fibrosis

- Inhibitors of protease activity

- Other pharmacological approaches to treatment

Are mast cells pro-fibrotic or anti-fibrotic 
Future directions 


\section{INTRODUCTION}

Fibrosis is a common and often serious complication of many diseases, including various kidney disorders, cancer, pulmonary pathologies such as asthma, idiopathic pulmonary fibrosis (IPF) and chronic obstructive pulmonary disease (COPD), liver diseases and cardiac disorders. The hallmark of fibrosis is the excessive accumulation of various extracellular matrix (ECM) components, most notably collagen, but also various other ECM components such as proteoglycans and fibronectin. The extensive accumulation of such compounds can lead to severe disturbances of normal organ function which can have lethal consequences ${ }^{1}$.

The exaggerated accumulation of ECM in fibrotic conditions is dependent on an expansion of the fibroblast population, which differentiates into contractile synthetic myofibroblasts characterized by the expression of $\alpha$-smooth muscle actin ( $\alpha$ SMA) and vimentin. Myofibroblasts are the principle cells responsible for the synthesis and deposition of the fibrotic matrix and associated tissue contraction evident within fibrotic tissues ${ }^{2}$. The mechanisms that trigger the excessive proliferation and activation of fibroblasts and their differentiation of fibroblasts to myofibroblasts may vary dependent on the respective pathology, but typically involve effects of pro-fibrotic growth factors such as TGF $\beta$, connective tissue growth factor (CTGF) and platelet-derived growth factor (PDGF), and other triggers such as angiotensin II (Ang II) and pro-inflammatory stimuli ${ }^{1}$.

Mast cells (MC) are hematopoietic cells of the immune system, contributing both to innate and adaptive immune responses. They are found as resident cells in all human tissues, with a particularly high density at sites close to the external environment, such as the skin and mucosal surfaces of the lung and gut (reviewed in ${ }^{3}$ ). MCs are characterized by a high content of secretory granules filled with various preformed compounds including biogenic amines (histamine), proteoglycans of serglycin type, certain preformed cytokines and growth factors 
(TNF $\alpha$, FGF-2, TGF $\beta$, IL-4), lysosomal hydrolases and various MC-restricted proteases ${ }^{4}$. When MCs are activated, for example by high affinity IgE receptor (FceRI) crosslinking, they degranulate and release their pre-formed granule mediators into the extracellular space. In addition, MC activation leads to the de novo generation of numerous compounds including a variety of cytokines, growth factors and chemokines as well as lipid-derived mediators such as platelet activating factor, leukotrienes and prostaglandins ${ }^{3}$.

MCs are known to have a beneficial role in protection against a variety of external insults such as various toxins and bacterial infection ${ }^{5,6}$, but are predominantly known for their detrimental impact in allergic conditions including asthma ${ }^{3}$. In addition, there is a vast documentation suggesting a role for MCs in various other disorders, including autoimmune diseases ${ }^{7}$, cardiac pathologies ${ }^{8,9}$, cancer ${ }^{10,11}$ and inflammatory kidney disease ${ }^{12}$. Moreover, there is substantial evidence pointing to a prominent role for MCs in fibrotic conditions, based on both clinical findings and studies in animal models. Here we review the current knowledge of how MCs contribute to the manifestations of fibrosis.

We will start by reviewing the circumstantial evidence that MCs contribute to human tissue fibrosis in various organs, before discussing the evidence that MC-derived mediators contribute directly or indirectly to the fibrotic process. We will then discuss the role of MCs in animal models of tissue fibrosis.

\section{Mast cells in human lung fibrosis}

The diffuse parenchymal (interstitial) lung diseases form a large, heterogeneous and complex group of conditions associated with the development of lung parenchymal fibrosis. There are many underlying causes or associations including connective tissue and autoimmune disorders (rheumatoid disease, systemic sclerosis, systemic lupus erythematosus), drugs 
(amiodarone, nitrofurantoin), organic antigens (from birds, mouldy hay), and inorganic molecules (asbestos, silica), but for many the cause is not known. The most common condition encountered in clinical practice is the condition known as idiopathic pulmonary fibrosis (IPF). This presents with progressive cough and breathlessness, with lung fibrosis and honeycombing present predominantly in a subpleural and basal lung distribution ${ }^{13}$. Its prevalence is increasing and median survival is only 3 years, worse than many cancers ${ }^{14-16}$. Existing treatments are of limited efficacy ${ }^{17,18}$

Histologically, IPF is characterised by patchy fibrosis demonstrating fibroblast foci, interspersed with relatively healthy areas of lung ${ }^{19}$. While the initiating events and role of inflammation in IPF remain unresolved, there is evidence of ongoing damage to the alveolar epithelium and capillary endothelium leading to unopposed activation of repair mechanisms 19. The chronicity of the insult leads to dysregulated repair with histological evidence of proliferation of type II pneumocytes and the generation of fibroblastic foci. These events are driven by several pro-fibrotic mediators. Epithelial injury stimulates the release of numerous mediators including TGF $\beta 1$, which is the key upstream pro-fibrotic growth factor driving IPF 20-24. Several additional pro-fibrotic mediators, cytokines, chemokines and growth factors including PDGF, FGF-2, IL-4, and IL-13 are released from many cell types and are likely to contribute to the fibrotic process ${ }^{25-29}$. Collectively these cytokines/growth factors contribute to the formation of fibroblast foci and the exaggerated deposition of extracellular matrix (ECM), destroying the lung parenchymal architecture. While different mechanisms may initiate lung fibrosis in other types of interstitial lung disease, the mechanisms leading to the deposition of fibrotic matrix are likely to overlap with those active in IPF.

The key cell depositing the abnormal fibrotic matrix and mediating the associated tissue contraction in all types of lung fibrosis is the myofibroblast ${ }^{24,30}$. Compared to cells from non- 
fibrotic lung, myofibroblasts derived from IPF lungs demonstrate enhanced aSMA expression ${ }^{31}$, actin stress fibre formation ${ }^{31}$, proliferation ${ }^{32}$, migration ${ }^{33}$, contraction ${ }^{34}$ and collagen production ${ }^{35}$. There is also impaired production of $\mathrm{PGE}_{2}{ }^{36}$, an inhibitor of healthy fibroblast proliferation and a known inhibitor of lung MC activation via FceRI ${ }^{37}$.

\section{- Mast cells infiltrate human fibrotic lung tissue}

There is strong evidence for important bidirectional interactions between MCs and myofibroblasts in fibrotic tissues that appear to exacerbate the fibrotic process in human lungs. MCs are numerous in healthy airways and lung parenchyma, but are increased in the fibrotic areas of alveolar parenchyma in patients with pulmonary fibrosis resulting from several diverse aetiologies including IPF ${ }^{25,38-46}$, connective tissue disease-associated lung fibrosis ${ }^{38,47}$, chronic hypersensitivity pneumonitis ${ }^{40,44}$, sarcoidosis ${ }^{25,38,44}$, chronic berylliosis ${ }^{25}$, silicosis ${ }^{48}$, bronchiolitis obliterans organising pneumonia ${ }^{44}$, Langerhans cell histiocytosis ${ }^{44}$, and infants with bronchopulmonary dysplasia ${ }^{49}$. Increased numbers of MCs have also been identified in the bronchoalveolar lavage (BAL) fluid of patients with various interstitial lung diseases although studies vary ${ }^{50-56}$, and in the alveolar spaces, particularly in hypersensitivity pneumonitis and BOOP ${ }^{44}$. These observations are in keeping with the original electron microscopic images taken by Kawanami et al. demonstrating MCs migrating through the alveolar basement membrane in patients with IPF but not "healthy" controls ${ }^{38}$. In patients with hypersensitivity pneumonitis, BAL MC numbers returned to normal ${ }^{57}$ or fell significantly but remained elevated after exposure to the offending agent was prevented ${ }^{55}$.

In several studies, the numbers of MCs present in fibrotic lung parenchyma or BAL has correlated strongly with the severity of fibrosis $25,39,44,58$. Negative correlations with lung function have also been recorded ${ }^{54}$. The number of MCs in BAL may also be prognostic. In 
patients with sarcoidosis, those with the highest MC counts in BAL at study entry, were the most likely to exhibit disease progression over the subsequent 2 years ${ }^{56}$.

\section{- Mast cell activation in human fibrotic lung tissue}

Morphologically, the MCs in the fibrotic parenchyma in patients with IPF and other interstitial lung diseases often show reduced numbers of granules and disorganised granule content, suggesting there is partial ongoing degranulation ${ }^{38,40,42,44}$ (Figure 1). There is also evidence for the increased release of tryptase within the tissue ${ }^{45}$. In keeping with this, histamine and/or tryptase concentrations are elevated in the BAL fluid of patients with IPF 43,50,51 hypersensitivity pneumonitis ${ }^{53,57}$, scleroderma ${ }^{47}$ and fibrotic sarcoidosis ${ }^{43,50}$. In patients with active hypersensitivity pneumonitis, BAL MCs appeared degranulated when viewed by electron microscopy ${ }^{51}$. In both normal and IPF lung, the majority of MCs and fibroblasts in the alveolar septae are apposed ${ }^{39,59}$ and this, coupled with evidence of ongoing MC activation suggests that there is likely to be intimate cross-talk between the two cell types. The exact mechanisms mast cell activation in human ILDs is not known but potential activation pathways are summarised in Figure 2.

\section{- Mast cell phenotype in human lung fibrosis}

A detailed phenotypic analysis of MCs in IPF lungs by Andersson et al. demonstrated that while total MC numbers are unchanged in healthy areas of IPF lungs, there is a decrease in the density of MCs expressing tryptase only $\left(\mathrm{MC}_{\mathrm{T}}\right)$ and an increase in the density of $\mathrm{MCs}$ expressing both tryptase and chymase $\left(\mathrm{MC}_{\mathrm{TC}}\right)$ in these areas ${ }^{58}$. In the fibrotic parenchyma, there was an increase in both $\mathrm{MC}_{\mathrm{T}}$ and $\mathrm{MC}_{\mathrm{TC}}$, but this was particularly noteworthy for $\mathrm{MC}_{\mathrm{TC}}$ cells, which are rarely found in healthy lung parenchyma ${ }^{58}$. Similar observations were made by Hirata et al. ${ }^{41}$, who also found a close correlation between $\mathrm{MC}_{\mathrm{TC}}$ and $\mathrm{IL}-4^{+}$cells, perhaps because $\mathrm{MC}_{\mathrm{TC}}$ commonly express IL-4 unlike $\mathrm{MC}_{\mathrm{T}}{ }^{60}$. Andersson ${ }^{58}$ also showed that 
approximately $10 \%$ of $\mathrm{MC}_{\mathrm{T}}$ expressed IL-6 in healthy airways, but that this was not present in $\mathrm{MC}_{\mathrm{TC}}$ in keeping with the work of Bradding et al. ${ }^{60}$. The proportion of $\mathrm{IL}^{-} 6^{+} \mathrm{MC}_{\mathrm{T}}$ increased to about $20 \%$ in IPF lung parenchyma, but $\mathrm{IL}^{-} 6^{+} \mathrm{MC}_{\mathrm{TC}}$ were rarely seen ${ }^{58}$. In contrast, there was a marked upregulation of TGF $\beta 1$ expression by MCs in the small airways and lung parenchyma in IPF, in both $\mathrm{MC}_{\mathrm{T}}$ and $\mathrm{MC}_{\mathrm{TC}}{ }^{58}$. This was particularly marked for $\mathrm{MC}_{\mathrm{TC}}$ where $\mathrm{TGF} \beta 1$ was rarely expressed in health but by almost $100 \%$ of $\mathrm{MC}_{\mathrm{TC}}$ in IPF. This demonstrates the marked plasticity of human lung MCs, and suggests that MCs develop a pro-fibrotic phenotype before the onset of fibrosis, and that MC-derived TGF $\beta 1$ is likely to make an important contribution to the fibrotic process. Furthermore, it also suggests that small airway dysfunction also contributes to IPF pathophysiology.

Fibroblast growth factor 2 (FGF-2, known previously as basic FGF) is another potent fibrogenic cytokine produced by human MCs ${ }^{25,61-64}$. In healthy alveolar parenchyma it was present in $30 \%$ of $\mathrm{MC}_{\mathrm{T}}$ cells but not $\mathrm{MC}_{\mathrm{TC}}$ cells ${ }^{64}$. Two laboratories have reported that the majority of tryptase ${ }^{+} \mathrm{MCs}$ in IPF and silicosis lung parenchyma express FGF-2 and are the most abundant cells expressing FGF-2 in both conditions ${ }^{25,48,62}$. Furthermore, the distribution of FGF-2 $2^{+}$MCs matched that of extracellular matrix deposition and correlated with the extent of fibrosis morphometrically, thus providing circumstantial evidence that MCs contribute to the fibrotic process 25 .

Stem cell factor (SCF) is an essential growth factor for human MCs, and mRNA expression for the transmembrane form, and SCF protein, are upregulated in IPF tissue where it is localised predominantly to myofibroblasts and hyperplastic alveolar type II cells ${ }^{42}$. Elevated mRNA expression for transmembrane SCF was also observed in IPF-derived fibroblasts compared to non-fibrotic control fibroblasts. This indicates that an appropriate microenvironment exists to account for the MC hyperplasia evident in fibrotic lung tissue. 
The presence of increased numbers of activated MCs expressing pro-fibrotic growth factors in IPF suggests that MCs are likely to contribute to fibroblast dysfunction in IPF. This is supported by in vitro studies and model systems as described in later sections.

\section{Mast cells in human chronic kidney disease}

Chronic kidney disease (CKD) is common, with an estimated global prevalence of between 11 to $13 \%{ }^{65}$. Irrespective of whether the initial pathology is focussed on the renal glomeruli, tubules or interstitium, chronic disease progresses to irreversible tubulointerstitial fibrosis (reviewed in ${ }^{66}$ and $^{67}$ ). As in many fibrotic conditions, it is believed that dysregulated epithelial repair processes result from repeated or chronic injury, driving an unregulated and progressive fibrotic response through the activation of matrix-producing myofibroblasts (reviewed in ${ }^{68}$ ). This leads to further loss of functioning nephrons and therefore progressive renal failure.

The general consensus is that MCs are present but relatively scarce in healthy human kidneys 69-71. There are many consistent reports of increased MC numbers in the cortical and medullary interstitium in numerous chronic kidney diseases including membranous nephropathy 70,72,73, lupus nephritis ${ }^{72,73}$, focal segmental glomerular sclerosis ${ }^{72,73}$, mesangiocapillary glomerulonephritis ${ }^{72}$, IgA nephropathy ${ }^{70,72-75}$, diabetic nephropathy ${ }^{70,72}$, hypertensive nephropathy ${ }^{76}$, renal amyloid ${ }^{77}$, chronic cyclosporin toxicity ${ }^{70}$, and chronic transplant rejection ${ }^{70,78-80}$. MCs were also markedly increased in the corticotubular interstitium of patients with rapidly progressive crescentic glomerulonephritis ${ }^{69}$. MCs are very rarely if ever observed within glomeruli ${ }^{69,70,73}$. The MCs present in diseased interstitium are predominantly of the $\mathrm{MC}_{\mathrm{T}}$ phenotype but a significant proportion of $\mathrm{MC}_{\mathrm{TC}}$ are also present although these vary in number depending on the disease (reviewed in ${ }^{12}$, see also $^{69,74,76,77,81}$ ). Chymase-only $\mathrm{MC}_{\mathrm{C}}$ have also been identified in chronic rejection ${ }^{79}$. 
In numerous studies the number of MCs present in CKD has correlated inversely with renal function ${ }^{69,74,75,77,79}$, and positively with the extent of fibrosis ${ }^{69-71,73-75,77,78}$, and the number of $\alpha \mathrm{SMA}^{+}$cells ${ }^{69,71,77,80}$. Furthermore, the number of MCs present in the renal interstitium at day 100 post renal transplantation, was strongly correlated with the decline in renal function at 3 years, and the change in fibrosis index at 3 years ${ }^{81}$. Ultrastructural studies show that the MCs in the fibrotic interstitium are activated ${ }^{70}$ and in close approximation to the resident myofibroblasts ${ }^{74}$. MCs in the fibrotic interstitium have been shown to contain FGF-2 ${ }^{74,77}$

Perhaps not surprisingly, SCF expression is increased in parallel with MC numbers in chronic glomerulopathies ${ }^{71}$ and hypertensive nephropathy ${ }^{76}$, and is likely to play an important role in promoting MC recruitment, survival and activation. SCF expression also correlates with the extent of interstitial fibrosis and $\alpha$ SMA expression ${ }^{71}$. Tryptase in the presence of heparin increased the proliferation of human renal fibroblasts cultured from diseased kidneys ${ }^{73}$, and increased the synthesis of fibronectin and collagen type 1. Protease-activated receptor 2 (PAR-2) is upregulated in IgA nephropathy, in both proximal tubular cells and the fibrotic interstitial infiltrate ${ }^{82}$. In cultured renal tubular cells and mesangial cells, activation of PAR-2 stimulated TGF $\beta 1$ synthesis ${ }^{82}$, implying that activation of PAR-2 by tryptase in vivo may be an important pathway promoting renal interstitial fibrosis.

Based on work from other systems, there are several further potential mechanisms whereby MCs might drive kidney fibrosis through the release of pro-fibrotic mediators, modulation of the renin-angiotensin system, cell-cell contact, and transgranulation with fibroblasts. However, there are no studies to-date that have studied this with primary human kidney MCs.

\section{Mast cells in human systemic sclerosis}

Systemic sclerosis (scleroderma) is a multi-system connective tissue disorder characterised 
by intimal proliferation and fibrosis in small arteries and arterioles, and degenerative changes with fibrosis in the skin and certain internal organs. Healthy skin contains numerous MCs, predominantly of the $\mathrm{MC}_{\mathrm{TC}}$ phenotype ${ }^{83}$. Hawkins et al. demonstrated that the MC density in clinically involved skin of patients with early stages of scleroderma was significantly greater than in clinically uninvolved skin of the same patients or in the skin of healthy controls ${ }^{84}$. However, MC counts in both clinically involved and uninvolved skin in late scleroderma were within the normal range. The increase in early stage disease occurred in both the papillary and reticular dermis. This increase in MC density in early stage disease was confirmed in further studies ${ }^{85,86}$. Irani et al. found normal or reduced numbers of MCs in the skin of patients with established scleroderma but noted an increased proportion of $\mathrm{MC}_{\mathrm{T}}$ cells ${ }^{87}$. In contrast, Seibold et al. ${ }^{88}$ found elevated MCs numbers in both involved and uninvolved skin in both early and late disease. There was also increased MC degranulation in early but not late disease, and also in currently healthy skin, suggesting that increases in MC numbers and degranulation precede clinically apparent dermal fibrosis. Falanga et al. ${ }^{89}$ reported raised histamine levels in the plasma of patients with systemic sclerosis providing further evidence of $\mathrm{MC}$ activation in this disease.

MCs present in scleroderma skin express TGF $\beta$ in their granules and demonstrate morphological features of degranulation when viewed by electron microscopy ${ }^{90}$. MCs and fibroblasts were adherent with numerous gap junctions between MCs and fibroblasts present, and with direct transfer of $\mathrm{MC}$ vesicles to fibroblasts evident ${ }^{91}$. Again this suggests the presence of important bi-directional interactions.

While there are inconsistencies in the above studies, overall they suggest that MCs may be important in the pathogenesis of the early cutaneous lesions of progressive systemic sclerosis. 


\section{Mast cell in human cardiac fibrosis}

Interstitial cardiac fibrosis is a feature of aging and commonly presents in a number of diverse cardiac diseases including ischaemic heart disease, dilated cardiomyopathy, diabetic cardiomyopathy, hypertrophic cardiomyopathy, hypertensive heart disease, and valvular heart disease (reviewed in ${ }^{92}$ ). This fibrotic response further impairs cardiac function and promotes arrhythmias. As in other fibrotic conditions, the key cell driving the fibrotic response is the myofibroblast.

MCs are present in healthy human hearts, located in the interstitium in close approximation to the muscle fibres and capillaries ${ }^{93}$. These cells are predominantly of the $\mathrm{MC}_{\mathrm{TC}}$ phenotype ${ }^{93}$ and have been isolated and extensively characterised ${ }^{93,94}$. Circumstantial evidence shows that MCs are associated with cardiac fibrosis and may be involved in its pathogenesis. For example, MCs analysed by electron microscopy appeared degranulated in endomyocardial biopsies from patients who had undergone cardiac transplantation, and the MC density correlated with the volume of fibrosis ${ }^{95}$. Furthermore, serial sampling demonstrated that those patients with the most MCs developed more fibrosis over time.

MC density was increased in the hearts of patients with idiopathic dilated or ischaemic cardiomyopathy undergoing cardiac transplantation, and this was accompanied by increased cardiac histamine and tryptase content ${ }^{96}$. MCs from patients with either type of cardiomyopathy released larger quantities histamine, tryptase and $\mathrm{LTC}_{4}$ than controls following activation with anti-IgE or SCF, suggesting the cells were primed for mediator release ${ }^{96}$. These cardiac MCs also contained SCF suggesting a possible autocrine role, in keeping with observations from other tissues ${ }^{97}$. In another study, the density of MCs correlated with the extent of fibrosis in patients with idiopathic cardiomyopathy ${ }^{98}$. 
Akgul et al. found a significant increase in MCs in end-stage dilated cardiomyopathy compared to healthy myocardium. MCs were localised particularly within areas of fibrosis and were the predominant source of FGF- $2{ }^{99}$. Following long term (>40 days) support with a left ventricular assist device, there was a further increase in $\mathrm{MC}$ numbers compared to patients who received short term support, but a shift from $\mathrm{MC}_{\mathrm{TC}}$ to $\mathrm{MC}_{\mathrm{T}}$, accompanied by a decrease in myocardial fibrosis and FGF-2 expression ${ }^{99}$. This might suggest the transition from a pro-fibrotic to anti-fibrotic MC phenotype.

\section{Mast cells in human liver fibrosis}

Hepatic fibrosis leading to cirrhosis is the final endpoint for many chronic liver diseases. Chronic inflammation in response to ongoing tissue injury is a common precursor, and this leads to accumulation of ECM deposited my myofibroblasts, with TGF $\beta 1$ again a central profibrotic mediator driving this response Progression to cirrhosis is variable but usually slow, developing over 20 to 40 years in patients with chronic liver injury (reviewed in ${ }^{100}$.

MCs are sparse in healthy human livers where they are found predominantly in the portal tracts associated with blood vessels and bile ducts, and to a lesser degree in the walls of the sinusoids ${ }^{101,102}$. Several studies have shown that MC numbers are increased in fibrotic human livers with numerous MCs in both the portal tracts and the fibrous septae ${ }^{101-105}$. This is evident with liver fibrosis of different aetiologies including alcoholic liver disease 101,102,104,105, hepatitis B 102,104,105, hepatitis C 102,104,105, autoimmune hepatitis 103,105,106, primary biliary cirrhosis (PBC) ${ }^{101,102,104-106}$, primary sclerosing cholangitis ${ }^{102,104}$, and cirrhosis of unknown cause ${ }^{102}$. In several studies the number of MCs correlated with the severity of fibrosis ${ }^{101,103,105}$. 
The MCs present in fibrotic livers are predominantly of the $\mathrm{MC}_{\mathrm{TC}}$ phenotype ${ }^{102,104,105}$, and also express basic FGF ${ }^{104}$. In one study, significantly more MCs were present in PBC compared to alcoholic liver disease for any given degree of fibrosis ${ }^{101}$. Histamine has been postulated as a cause of itching in cholestasis, with increased concentrations present in patients with cholestasis including PBC ${ }^{107}$. This is turn suggests that there is increased MC activation in PBC, which might be initiated by exposure to bile acids, which induce MC degranulation in a murine MC line ${ }^{108}$.

\section{Human mast cell-fibroblast cross-talk in the pathogenesis of fibrosis}

MCs produce a plethora of autacoid mediators, proteases, cytokines, chemokines, growth factors and other molecules which demonstrate pro-fibrotic activity, either directly through effects on fibroblasts and fibrocytes, or indirectly through the recruitment and activation of various inflammatory and structural cell types (summarised in tables 1-3 and figure 3). However, MCs also produce molecules that exert potential anti-fibrotic activity, and this, coupled with the ability of certain mediators to change the response to other mediators, makes it difficult to predict exactly how important individual mediators are in regulating fibrosis. While tables 1-3 give an overview of the most consistent effects seen with the different mediators listed, there is nevertheless inconsistent data with regards to their individual effects, even when using cells from the same sources as highlighted in some instances below.

Ex vivo co-culture of MCs with fibroblasts partially addresses the problems of studying individual mediators, although MC heterogeneity between species and tissues may also lead to inconsistencies between studies. However, as combinations of mediators are produced in 
potentially physiological concentrations this allows a more global assessment of the MCfibroblast interaction. The effects of cell-cell contact can also be taken into account.

\section{- Mast cell mediators acting on human fibroblasts}

Briefly, in humans histamine, FGF-2, and TNF $\alpha$ stimulate fibroblast proliferation ${ }^{109-112}$. TNF $\alpha$ is also a fibroblast chemoattractant ${ }^{113}$, and stimulates matrix protein and collagenase production from human lung fibroblasts ${ }^{112,114}$. IL-4 is a chemoattractant for human fibroblasts ${ }^{115}$ and both IL-4 and IL-13 promote fibroblast proliferation and differentiation, and trigger the release of matrix proteins, chemokines and inflammatory cytokines from human airway and skin fibroblasts ${ }^{116-123}$. In addition, heparin indirectly potentiates fibroblast activation and proliferation by regulating FGF-2 bioactivity; heparin provides structural stability for FGF-2 and preserves its bioactivity by protecting it from degradation ${ }^{124}$. Furthermore, heparin and/or heparan sulphate facilitate the release of FGF-2 from its basement membrane storage location and the binding of FGF-2 to its receptors ${ }^{125}$.

Lung MC-derived TGF $\beta 1$ also has the potential to induce fibroblast differentiation into contractile myofibroblasts, as does human lung MC-derived tryptase which induces TGF $\beta 1$ release from human airway smooth muscle cells leading to the autocrine upregulation of $\alpha \mathrm{SMA}$, which in turn leads to increased contractility ${ }^{126}$. Tryptase has similar effects on human dermal fibroblasts ${ }^{127}$. Lastly, recombinant amphiregulin induces the proliferation of human airway fibroblasts but not airway smooth muscle (ASM) cells, suggesting a further mechanism whereby MCs might contribute to fibrosis ${ }^{128}$.

MC proteases have important effects on fibroblast function, and are favoured as key fibrotic molecules release by MCs. MCs express high levels of a number of proteases that are essentially restricted to this cell type, including tryptase, chymase and carboxypeptidase A3 
(CPA3). These proteases are stored in the secretory granules of MCs and are thus released in large quantities when MCs are stimulated to degranulate. Tryptase induces proliferation, chemotaxis, collagen synthesis and migration in human fibroblasts ${ }^{129-131}$ (see table 1). In many of these studies it was suggested that tryptase exerts its effects on fibroblasts by activating PAR-2 receptors on the fibroblast surface, and there is evidence to suggest that tryptaseinduced PAR-2 activation and associated proliferation is mediated by prostaglandin 15deoxy-Delta(12,14)-prostaglandin $\mathrm{J}(2)$ acting via PPAR $\gamma^{132}$. There is also clinical evidence linking chymase expression to fibrosis as described above, as well as many potential profibrotic and anti-fibrotic activities (see table 1). MC proteases will be discussed further in relation to animal models later.

\section{- Bi-directional human mast cell-fibroblast cross-talk in co-culture}

MCs interact with fibroblasts via direct contact which activates both cell types with or without additional stimuli. For example, cultured rat fibroblasts use long cytoplasmic processes to phagocytose and internalise rat MC granules, a process termed transgranulation by Greenberg and Woodstock ${ }^{133}$. This uptake of granules is followed by secretion of collagenase and $\beta$ hexosaminidase ${ }^{134}$.

It is well established that fibroblasts maintain human MC survival. Primary human MCs die rapidly in the absence of exogenous growth factors, but in 1997 Levi-Schaffer and colleagues demonstrated that mouse skin 3T3 fibroblasts maintain the survival of primary human lung MCs over a period of 13 days in the absence of exogenous growth factors ${ }^{135}$. The cells did not appear to form tight junctions and MC proliferation was not detected, but the MCs maintained their phenotype in terms of general morphology, granule morphology, mediator content and their response to secretogogues. The same researchers then showed that human skin MCs also maintain their survival, morphology, histamine content and response to 
secretogogues when co-cultured with human foreskin-derived fibroblasts for 8 days ${ }^{136}$. Similar results have been demonstrated for the co-culture of gut-derived human MCs with gut fibroblasts ${ }^{137}$, and human lung MCs with primary human lung fibroblasts ${ }^{138}$. However, unlike the original work of Levi-Schaffer, human lung MCs appear to proliferate rapidly in the presence of human lung fibroblasts, confirmed by two independent laboratories ${ }^{42,138}$. The gut MC survival response was interestingly mediated by IL-6 rather than SCF ${ }^{137,139}$, while the lung MC survival response was mediated in part by SCF but also required MC-fibroblast contact ${ }^{42}$. The lung MC proliferative response also involved MC-fibroblast adhesion mediated in part by the adhesion molecule CADM1 ${ }^{138}$, described further below.

In a 3-cell organotypic skin-equivalent culture system comprising neonatal dermal fibroblasts and the human MC line HMC-1 cells embedded in a collagen gel with keratinocytes cultured above this composite culture, there was a "constitutive" increase in the expression of type a1(I) procollagen mRNA in fibroblasts analysed by in situ hybridisation ${ }^{131}$. Tryptase was the key factor mediating this effect and also promoted fibroblast chemotaxis. Other studies demonstrated that co-culture of human dermal fibroblasts with HMC-1 cells increases the differentiation of fibroblasts to myofibroblasts and increases the contraction of fibroblasts in three-dimensional collagen lattices ${ }^{127,140}$. In one study, addition of culture supernatants of MCs did not enhance the speed of gel contraction unlike co-culture, suggesting the importance of cell-cell contact, supported by the close approximation of the two cell types within the collagen gel ${ }^{140}$. In this study, adding neutralising antibodies against SCF and Kit inhibited gel contraction up to $70 \%$. However, in another study, histamine contributed to the increase in fibroblast $\alpha$ SMA expression, while tryptase increased both $\alpha$ SMA expression and fibroblast contraction ${ }^{127}$. 
Heterotypic cell-cell contact between either HMC-1 cells or human skin MCs with human skin fibroblasts augmented fibroblast proliferation and required the expression of MC-associated IL$4{ }^{117}$. In this study, although IL-4 was present in the lysates of HMC-1 cells it could not be detected in the supernatant of the co-culture system. This suggests that IL-4 was secreted by MCs in low amounts and was strictly limited to cell-cell contacts with fibroblasts. Interestingly, it has previously been proposed that MCs may present IL-4 on their surface in order to confer local cytokine specificity ${ }^{141}$ (IL-4 is a heparin-binding cytokine is therefore likely to be retained on the MC surface bound to heparin proteoglycans ${ }^{142}$ ). This would be analogous to the recently described MC antibody-dependent degranulatory synapse ${ }^{143}$.

These findings appear relevant to the in vivo situation. Using immunohistology and in situ hybridization, a five-fold increase in the density of tryptase ${ }^{+} \mathrm{MCs}$ was observed at the fibrotic border in a human skin wound model, which appeared dependent on the increased recruitment/survival of resident MCs or freshly recruited MC progenitors rather than local proliferation ${ }^{144}$. Recruitment of MCs was paralleled by the increased expression CCL2. Notably, approximately $65 \%$ of MCs exhibited strong and selective IL-4 immunoreactivity, whereas other resident and passenger cells appeared quiescent. Taken together with the in vitro studies of Trautmann et al, these data suggest that MCs make an important contribution to human wound repair via MC-derived CCL2, IL-4 and stimulation of fibroblast proliferation.

A study co-culturing healthy human lung fibroblasts (NHLF) with HMC-1 cells demonstrated contact-dependent secretion of IL-6 into the culture supernatant ${ }^{145}$. HMC-1-derived cellular membranes also stimulated an increase in IL-6 production in the lung fibroblasts. Blockade of ICAM-1, TNF-RI, or surface IL-1 $\beta$ with neutralizing antibodies failed to significantly decrease IL-6 production in these co-cultures. This production of IL-6 is consistent with 
subsequent studies examining the interaction of gut fibroblasts with gut MCs ${ }^{139}$, and human lung MCs with human ASM cells ${ }^{146}$, where IL-6 contributed to the maintenance of MC survival.

In another study the co-culture of HMC-1 cells with primary bronchial fibroblasts isolated from bronchial biopsies of subjects with mild asthma and healthy controls increased procollagen I $\alpha 1$ gene expression by fibroblasts from subjects with asthma ${ }^{147}$. HMC-1 cells expressed both the common IL-4 isoform and IL-482, an alternative splice variant of IL-4. Co-culture significantly increased the expression of IL-4 but not IL-4delta2 by HMC-1 cells when they were cultured with fibroblasts from subjects with asthma compared with cells from healthy controls. Neutralization of IL-4 abrogated collagen mRNA expression. There was no significant change in IL-4Ralpha or IL-13Ralpha1. However, IL-13Ralpha2 gene expression was significantly reduced in fibroblasts from subjects with asthma. This highlights the potential for airway fibroblasts to stimulate IL-4 expression in the HMC-1 cell line leading in turn to increased fibroblast pro-fibrotic activity.

The mechanism(s) by which fibroblasts activate MCs is likely to be facilitated by CADM1 and Kit-dependent adhesion (see below), but the intracellular signalling pathways and mechanisms of degranulation are not known. Carbon-fiber microelectrode amperometry (CFMA) is a useful method to examine the biophysical mechanisms of exocytosis under varied cell culture conditions. While no studies are reported using human cells, degranulation and serotonin exocytosis from mouse peritoneal MCs has been measured in the presence or absence mouse 3 T3 fibroblasts using the CFMA technique ${ }^{148}$.

More recently, co-culture of human peripheral blood-derived MCs induced human lung fibroblast collagen production and contraction in collagen gels following FceRI-dependent activation ${ }^{149}$. MMP-2 and -3 derived from MCs were important for these effects, likely via 
the activation of latent TGF $\beta 1$. In another study, human lung MCs induced the proliferation of human lung fibroblasts in co-culture ${ }^{42}$. This was associated with the contact-dependent activation of MCs by fibroblasts leading to increased tryptase secretion, which was the primary factor responsible for the fibroblast proliferation observed ${ }^{42}$. Gut MCs increased IL6 and MMP-1 production in co-culture with gut fibroblasts ${ }^{139}$, although it is possible that these mediators were derived from both cell types.

Co-culture of human gingival fibroblasts with HMC-1 cells stimulated the release of IL-8 into the culture medium ${ }^{150}$. This study was interesting because not only did the increased IL8 secretion require $\mathrm{HMC}$-1-fibroblast intercellular contact, it was blocked by the gap junction inhibitor $\beta$-glycyrrhetinic. Calcein-dye transfer showed intercellular, gap junction communication between HMC-1 and fibroblasts that was dependent in part on hyaluronic acid on the cell surface of fibroblasts.

MCs in co-culture with fibroblasts may also exhibit anti-fibrotic activity. Adrenomedullin is produced by vascular walls and demonstrates anti-fibrotic activity in the process of cardiovascular remodelling. In patients with abdominal aortic aneurysm, MCs in the outer media and adventitia of the aorta are increased compared to non-aneurysmal atherosclerotic aorta, and express strong adrenomedullin immunoreactivity ${ }^{151}$. When HMC-1 cells were cultured with fibroblasts isolated from aneurysmal patients, they released adrenomedullin into the cultured media, and collagen synthesis by fibroblasts was reduced in an adrenomedullin-sensitive manner.

In summary, MCs secrete many mediators that are pro-fibrotic, and human MCs from various sources become activated and release many of these mediators when in contact with fibroblasts from various tissues. The overall picture is one of pro-fibrotic activity when in co-culture with fibroblasts, with a supportive two-way interaction between the two cell types. Current data 
suggest that tryptase released from MCs may be particularly important in promoting fibroblast pro-fibrotic activity, although other mediators undoubtedly contribute. The distribution of MCs, their mediator expression, and morphological features of activation in human fibrotic tissues, coupled with clinical correlates and functional data from co-culture studies, suggests that in many scenarios, interactions between MCs and fibroblasts play a central role in the development and propagation of tissue fibrosis.

\section{The mechanisms and importance of mast cell-fibroblast adhesion via CADM1}

Cell adhesion is a fundamental mechanism facilitating cell communication through the delivery of contact-dependent signals together with the targeted release of soluble mediators. Human MCs adhere avidly to human fibroblasts. The two key molecules involved appear to be Kit and CADM1 expressed on MCs, and transmembrane SCF and a ligand for CADM1 (likely CADM1 also) expressed on fibroblasts respectively ${ }^{3}$. However, there is some inconsistency over the contribution made by Kit-SCF.

Several animal studies showed that mouse MCs adhere to mouse fibroblasts through a SCFKit-dependent mechanism ${ }^{152}$. However, the situation in humans is more complex. Initial studies examining the adhesion of HMC-1 and primary human skin MCs to human foetal fibroblasts demonstrated avid adhesion, but none of the adhesion molecules including integrins recognised at the time were involved ${ }^{153}$. SCF-Kit did not contribute to adhesion and the authors concluded that the process involved "not-yet-defined heterotypic cell-cell adhesion receptors". Although human airway epithelial cells and ASM cells express transmembrane SCF, we were also unable to find a role for SCF-Kit in the adhesion of human lung MCs to these structural cells using well validated SCF and Kit neutralising antibodies ${ }^{154,155}$. However, we have found that a non function-blocking anti-Kit single chain Fv antibody that was raised against human lung MC and HMC-1 cell membrane proteins 
does partially inhibit human lung MC adhesion to both airway epithelial cells and ASM cells 156. As Kit is a member of the Ig superfamily, it is therefore plausible that it mediates cell-cell adhesion outside the SCF-binding domain.

In 2003 Ito et al. demonstrated that CADM1 (also known as Necl2/IGSF4/RA175/SgIGSF/TSLC1/SynCAM1) plays an important role in the adhesion of mouse MCs to mouse fibroblasts ${ }^{157}$. Subsequent work has demonstrated that CADM1 plays an important role in the adhesion of human lung MCs to both human ASM cells and human lung fibroblasts ${ }^{138,155}$.

CADM1 is an adhesion receptor and another member of the immunoglobulin (Ig) superfamily and is particularly important for MC function and for signalling through Kit 3,138,158-160. Its altered expression is implicated in several diseases including cancer (due to its roles in tumour suppression) 161,162, autism spectrum disorder 163,164, venous thromboembolism ${ }^{165}$, and of relevance to this article, pulmonary fibrosis ${ }^{166}$. CADM1 binds to itself (homophilic adhesion) and to heterophilic binding partners including CADM2, CADM3, Nectin-3, and cytotoxic and regulatory T cell molecule (CRTAM) ${ }^{167-169}$, all of which are members of the same Ig superfamily. CADM1 is expressed in epithelial cells, nerves, endothelial cells, fibroblasts and MCs, but not other leukocytes. The only exceptions are the malignant $\mathrm{T}$ cells in adult $\mathrm{T}$ cell leukaemia/lymphoma (ATLL) ${ }^{170}$. The likely binding partner for CADM1 on human lung fibroblasts is CADM1 itself ${ }^{138}$.

CADM1 consists of several different splice variants, many of which are expressed by human MCs ${ }^{159}$. The activities of each CADM-1 isoform in MCs differ. For instance, the SP4 isoform mediates homotypic (MC-MC) adhesion through a homophilic (CADM1-CADM1) trans-interaction, and also promotes human lung MC and HMC-1 survival in mono-culture, although these two processes are not entirely interdependent ${ }^{160}$. CADM1 downregulation 
results in reduced MC viability in mono-culture and decreases expression of the pro-survival protein Mcl-1L, but not Blc-2 or Bcl-XL, and increases caspase-3/7 activity in both HMC-1 cells and human lung MCs ${ }^{160}$. This coincides with decreased basal Kit levels in human lung MCs.

CADM1 is also required for the efficient function of integrin-dependent $\mathrm{MC}$ adhesion to extracellular matrix. CADM1 regulates both E-cadherin and $\alpha_{6} \beta_{4}$ integrin function in other cell types ${ }^{171-173}$, and downregulation of CADM1 in HMC-1 cells results not only in reduced adhesion to human ASM cells, but also reduced adhesion to their extracellular matrix ${ }^{158}$. Time-course studies have demonstrated that CADM1 provides fast initial adhesion to human ASM cells and assists with slower adhesion to the extracellular matrix. However, since CADM1 downregulation, but not antibody-dependent CADM1 inhibition, reduced MC adhesion to the extracellular matrix, it is thought that CADM1 indirectly regulates extracellular matrix adhesion. CADM1 expression positively correlated with surface Kit levels and polymerisation of cortical F-actin in HMC-1 cells and also influenced phosphotyrosine signalling and Kit tyrosine auto-phosphorylation.

The CADM1-dependent adhesive process promotes MC survival and proliferation in cocultures of ASM cells and fibroblasts in the absence of serum and exogenous SCF or IL-6 138,146. More extensive experiments with human ASM cells have suggested that CADM1 and Kit have an intimate relationship in MCs. For example, CADM1 and Kit cooperate and contribute to human lung MC survival and proliferation ${ }^{146}$. In addition, both CADM1 and Kit exist under the transcriptional control of micropthalmia transcription factor (MITF) ${ }^{157,174}$, co-immunoprecipitate from HMC-1 cells ${ }^{146}$, and co-localise in human lung MCs at points of adhesion to human ASM cells, as determined by confocal imaging ${ }^{146}$. Downregulation or overexpression of CADM1 also reduces or increases, respectively, surface Kit expression in 
both human lung MCs and HMC-1 cells ${ }^{158,160}$. Thus, it is thought that CADM-1 plays an important role localising Kit to the surface of MCs at points of cell-cell adhesion. This will facilitate the interaction between Kit and membrane-bound SCF expressed on cells such as fibroblasts and ASM cells, hence promoting MC survival.

In summary, CADM-1 is an important adhesion molecule that interacts with Kit in a cooperative manner to promote MC survival, and is involved in the adhesion of human lung MCs to human lung fibroblasts. Targeting MC-specific CADM1 signal transduction pathways or inhibiting the function of its counter-receptors on fibroblasts has the potential to become a novel strategy for the inhibition of MC function in fibrosis.

\section{Approaches to studying mast cell function in animal models}

Based on the strong implications derived from clinical findings and in vitro studies that MCs drive fibrosis, investigators have sought to use animal models to address how MCs potentially may impact on fibrotic conditions. Such studies have mainly been conducted in mice and rats, but also models in hamsters, dogs and rabbits have been evaluated.

A particularly powerful strategy to assess the role of MCs in fibrosis has been to use various mouse and rat models in which MCs are absent. Most of these studies have been performed on animals in which MC deficiency is attributed to defects in Kit signaling will result in a profound reduction (although not total eradication) of MCs in these animals. However, as ckit expression is not exclusive for MCs, animals with defects in Kit also have a number of additional abnormalities, with differing phenotype depending on which type of Kit alteration the animal model harbours ${ }^{175}$. To account for this issue, investigators have developed elegant techniques for reconstitution of the MC niche in these animals, and if such MC reconstitution reverts the phenotype to that of WT mice, this has been taken as evidence that the observed phenotypic effects seen in the MC-deficient animals indeed are due to their MC-deficiency 
rather than to off target effects of defective c-kit signaling ${ }^{175}$. More recently, investigators have developed novel models for MC deficiency, by generating mice in which MC deficiency is independent of aberrant c-kit signaling. Typically, such models have utilized the highly MC-restricted expression of certain proteases, especially chymase and CPA3, and investigators have developed different strategies for depleting MCs by utilising the strong promoters for these proteases ${ }^{175}$. Intriguingly, by evaluating these novel models for MC deficiency, it was found that certain findings based on studies of c-kit-defective animals could not be replicated, and it has been suggested that the impact of MCs on various pathological settings therefore needs to be readdressed by using these novel models of MC deficiency ${ }^{176}$.

By using various models of MC-deficiency, a large number of studies have addressed the role of MCs in models of fibrosis. In particular, researchers have focused on the impact of MCs on lung, kidney, skin, heart, and liver fibrosis. As detailed below, these studies have provided partly conflicting results as to the contribution of MCs in fibrosis, with some studies indicating a detrimental role for MCs whereas others indicate that MCs are protective, and yet others indicate that MCs do not influence fibrosis in either direction (Table 4).

\section{Mast cells in models of lung fibrosis}

In an early study on this topic, rats were subjected to bleomycin-induced lung fibrosis. As a sign of MC involvement in this condition, lung histamine levels were dramatically increased and a profound MC hyperplasia of the lung parenchyma was observed ${ }^{177}$. Pulmonary fibrosis can also be induced by radiation, and X-ray irradiation of rats caused progressive lung fibrosis accompanied by dramatic pulmonary MC hyperplasia ${ }^{178}$. As a sign of MC activation, a pronounced elevation of pulmonary histamine and serotonin was seen ${ }^{178}$. Notably, there was a close correlation between MC densities and levels of the respective amines. Increased 
numbers of MCs accompanied by elevated histamine levels were also seen in asbestosinduced fibrosis in rats ${ }^{179}$.

When evaluating the functional impact of MCs in bleomycin-induced lung fibrosis by using MC-deficient $\mathrm{W} / \mathrm{W}^{\mathrm{v}}$ mice, Mori et al. ${ }^{180}$ showed that the grade of fibrosis was approximately equal in MC-competent compared to MC-deficient mice. Notably though, the content of hydroxyproline (a marker for collagen content) was higher in lungs of MC-deficient versus MC-competent mice, suggesting that MCs actually may confer protection against fibrosis ${ }^{180}$. In agreement with a protective role of MCs in lung fibrosis, Okazaki et al. showed that the extent of bleomycin-induced lung fibrosis was higher in MC-deficient Ws/Ws rats than in MC-competent animals ${ }^{181}$. In contrast, when assessing the airway fibrotic reaction in response to an allergen provocation, Masuda et al. found that the extent of fibrosis was diminished in MC-deficient (W/W $\mathrm{W}^{\mathrm{v}}$ or $\mathrm{Sl} / \mathrm{Sld}$ ) versus -competent mice ${ }^{182}$. A pro-fibrotic role of MCs in allergic airway inflammation is also supported by another study ${ }^{183}$. A detrimental impact of MCs in lung fibrosis is additionally supported through studies where MCcompetent and MC-deficient $\mathrm{W}^{\text {sh }} / \mathrm{W}^{\text {sh }}{ }^{184}, \mathrm{~W} / \mathrm{W}^{\mathrm{v}} 185$ or $\mathrm{mi} / \mathrm{mi}{ }^{186}$ mice, respectively, were subjected to bleomycin administration.

\section{MCs in models of kidney fibrosis}

Increased MC infiltration has been observed in various animal models of kidney fibrosis, including nephropathy induced by protein overload ${ }^{187}$ and the unilateral ureteral obstruction model ${ }^{188}$. In a study conducted on MC-competent versus MC-deficient Ws/Ws rats, Miazawa

et al. ${ }^{189}$ found that fibrosis occurring in conjunction with puromycin aminonucleosidenephrosis was not MC-dependent. In fact, the MC-deficient animals exhibited more severe fibrosis than did the MC-sufficient control animals, again suggesting that MCs may be protective. In a subsequent study, Kim et al. ${ }^{190}$ evaluated MC-deficient W/W $\mathrm{W}^{\mathrm{v}}$ mice in renal 
fibrosis induced by unilateral ureteral obstruction. They also found that the MC-deficient mice developed a more severe fibrosis than did the MC-sufficient control mice, suggesting a protective effect of MCs. Moreover, it was demonstrated that reconstitution of the MC niche reversed this phenotype back to that of the MC-sufficient control animals. Mechanistically, it was found that the MC-deficient animals exhibited higher levels of TGF $\beta$ and epithelial to mesenchymal transition (EMT) markers (E-cadherin) than did the control animals, suggesting that MCs protect against fibrosis by regulating the levels of TGF $\beta$ and by affecting EMT ${ }^{190}$. At variance with these findings, subsequent studies by Veerappan et al. ${ }^{188}$ and Summers et al. ${ }^{191}$ indicated that MCs contributed to the fibrotic lesions developing after unilateral ureteral obstruction, and it was suggested that MCs promote renal fibrosis by expressing renin leading to formation of pro-fibrotic Ang II ${ }^{188}$, or by enhancing the expression of TGF $\beta$ and $\alpha \mathrm{SMA}^{191}$.

\section{Mast cells in models of skin fibrosis}

By inducing graft-versus-host disease in mice, Claman et al. showed that this condition was associated with fibrosis-like lesions of the skin and that MC numbers were substantially reduced, possibly as a consequence of extensive degranulation ${ }^{192}$. To functionally evaluate the role of MCs in skin fibrosis, Everett et al. generated MC-deficient $\left(\mathrm{W} / \mathrm{W}^{v}\right)$ mice carrying the tight-skin (Tsk) mutation leading to spontaneous skin fibrosis. The authors showed that the early fibrotic lesions did not differ between MC-competent and -deficient mice, but when examining late stages of fibrosis (5-7 months), MCs significantly augmented the skin fibrosis 193. MCs (using the W/W ${ }^{\mathrm{v}}$ mice and reconstitution approach) were also shown to augment the skin fibrosis occurring in response to biomaterial implantation ${ }^{194}$. However, when addressing the role of MCs in bleomycin-induced skin fibrosis by using novel MC-deficient models 
where MC deficiency is independent of defective c-kit signaling, Willenborg et al. found that MCs did not affect the development of fibrotic lesions ${ }^{195}$.

\section{MCs in models of cardiac fibrosis}

In a model of inflammatory cardiac fibrosis induced by Coxsackievirus B3 virus there was a marked increase in the number of degranulated MCs, suggesting that MCs may contribute to the pathogenesis ${ }^{196}$. Increased numbers of MCs have also been observed in the fibrosis occurring in models of autoimmune myocarditis ${ }^{197}$ and in post transplantation hearts ${ }^{198}$. To address the functional impact of MCs on cardiac fibrosis, Liao et al. subjected fully MCcompetent mice, as well as mice that were reconstituted with bone marrow from MCdeficient $\mathrm{W} / \mathrm{W}^{\mathrm{v}}$ mice, to pressure overload leading to atrial fibrosis ${ }^{199}$. They showed that the fibrotic lesions were reduced in mice reconstituted with bone marrow from MC-deficient mice, suggesting that MCs contribute to the pathogenesis. The authors proposed that MCs promote fibrosis by expressing PDGF-A, and that MC-derived PDGF-A induces proliferation and collagen expression in cardiac fibroblasts. In a transgenic model with fibrosis occurring after cardiac-restricted overexpression of TNF $\alpha$, MC hyperplasia accompanied the development of cardiac fibrosis ${ }^{200}$. Moreover, by backcrossing the TNF $\alpha$-overexpressing mice to MC-deficient $\mathrm{W} / \mathrm{W}^{\mathrm{v}}$ mice it was shown that $\mathrm{MCs}$ were essential for the development of fibrosis in this model, suggesting that MCs are a primary target for the effects mediated by TNF $\alpha$. The authors also demonstrated that MC deficiency resulted in attenuation of TGF $\beta$ levels, and it was demonstrated that MCs enhanced the proliferation of fibroblasts and induced expression of both $\alpha$ SMA and collagen ${ }^{200}$. 


\section{MCs in models of liver fibrosis}

It was observed that $\mathrm{MC}$ numbers increase during experimentally-induced liver fibrosis in rats, and that liver fibroblasts were activated with enhanced collagen synthesis after phagocytosing granules released from liver MCs ${ }^{201}$. MC hyperplasia and a close spatial connection between MCs and fibroblasts was also seen when inducing liver fibrosis by diethylnitrosamine (DEN) ${ }^{202}$. MC hyperplasia was also observed in liver fibrosis induced by pig serum ${ }^{203}$, after administration of $\mathrm{CCl}_{4}{ }^{102}$ and after administration of amorphous silica nanoparticles ${ }^{204}$. However, arguing against a major role of MCs in inducing liver fibrosis, Okazaki et al. found that the extent of pig serum-induced liver fibrosis was not suppressed in MC-deficient Ws/Ws rats versus MC-competent animals ${ }^{181}$. In fact, the grade of fibrosis was elevated in the MC-deficient animals, suggesting that MCs actually confer protection ${ }^{181}$. Similarly, Sugihara et al. found that the absence of MCs in Ws/Ws rats or in $\mathrm{W} / \mathrm{W}^{\mathrm{v}}$ mice did not cause any reduction in the fibrotic lesions occurring in response to $\mathrm{CCl}_{4}$ or pig serum ${ }^{205}$. Instead, the collagen content (as marked by hydroxyproline content) was somewhat higher in the MC-deficient as compared with the MC-competent rats, suggesting a protective role of MCs ${ }^{205}$. In contrast to these studies, the extent of liver fibrosis developing after bile duct ligation was reduced in $\mathrm{MC}$-deficient $\mathrm{W}^{\mathrm{sh}} / \mathrm{W}^{\text {sh }}$ mice in comparison with MC-sufficient controls ${ }^{206}$.

\section{MCs in models of lymph node fibrosis}

It has been shown that the MC numbers tend to increase in rat lymph nodes during aging and it has also been demonstrated that this increase in MC density is associated with lymph node fibrosis ${ }^{207}$. In keeping with this, MC numbers were increased in the fibrotic lymph nodes of patients with diffuse large B cell lymphoma ${ }^{208}$. 


\section{MCs in models of adipose tissue fibrosis}

In a study by Hirai et al. it was found that MCs accumulate in fibrotic areas of adipose tissue in severely obese diabetic $\mathrm{db} / \mathrm{db}$ mice ${ }^{209}$. Interestingly, conditioned medium from the adipose tissue enhanced the production of collagen expression in NIH-33T3 fibroblasts, and this induction could be blocked by antagonizing MC tryptase (mMCP6). Hence, this suggests that MCs can promote fibrosis by tryptase-dependent activation of fibroblasts ${ }^{209}$.

\section{MC proteases in models of fibrosis}

In addition to the clinical and in vitro data supporting a role for MC proteases in fibrosis, animal models have allowed the dynamic manipulation of MC protease expression.

To evaluate the functional impact of chymase on kidney fibrosis, Scandiuzzi et al. subjected wild type (WT) and chymase deficient $\left(\mathrm{Mcpt}^{-{ }^{--}}{ }^{\text {; }}\right.$ also denoted $\left.\mathrm{mMCP}^{-/-}\right)$mice to immune complex-mediated glomerulonephritis, and showed that the fibrotic scores were lower in the chymase-deficient vs. WT animals ${ }^{210}$. The authors also demonstrated that the chymasedeficient mice had lower levels of Ang II, a pro-fibrotic peptide, than did the WT animals, and they also showed that the expression of collagen type I was reduced in the chymasedeficient mice ${ }^{210}$. A detrimental role of chymase in fibrosis is also supported by a study where $\mathrm{Mcpt}^{-/-}$mice were evaluated in bleomycin-induced lung fibrosis ${ }^{201}$. In addition, chymase Mcpt4 was shown to contribute to the fibrosis seen after burn injury in mice ${ }^{211}$. On the other hand, when evaluating the Mcpt $4^{-/-}$mice in the unilateral ureteral obstruction model, it was found that Mcpt4 in fact conferred protection against renal fibrosis, as reflected by higher collagen and fibronectin deposition, higher TGF $\beta$ levels, higher $\alpha$ SMA expression and decreased E-cadherin expression in comparison with WT animals ${ }^{212}$. Interestingly, when examining lung and skin tissue taken from naïve $\mathrm{Mcpt}^{-/-}$mice, i.e. not challenged with pro- 
fibrotic stimuli, Tchougounova et al. noted that the mice developed mild fibrosis of the skin and lung spontaneously as manifested by increases in collagen, hydroxyproline and fibronectin deposition ${ }^{213,214}$. Hence, these data are in concordance with a role for chymase in protection against fibrosis.

A number of observations have provided mechanistic insight into how the MC proteases can affect fibrosis. As noted above, several studies have provided a link between MCs and Ang II production in the context of fibrosis. In agreement with this notion, there is substantial evidence to suggest that chymase has major role in the ACE-independent generation of active Ang II from Ang I ${ }^{215}$, and it is thus likely that it is the action of chymase that accounts for MC-dependent formation of this pro-fibrotic peptide. There are also several studies supporting a link between MCs and TGF $\beta$. MCs have been shown to express this growth factor in large amounts and to store it within their secretory granules ${ }^{61,216}$. Further, there is evidence that MC chymase can convert the latent form of TGF $\beta$ into active growth factor, hence providing a mechanistic explanation for the MC-dependent release of active TGF ${ }^{217}$.

There are also numerous studies suggesting that MC proteases can have either indirect or direct effects on various connective tissue components, leading to their degradation. An important example of indirects effect of the MC proteases is the ability of chymase to activate pro-MMP9 into active protease ${ }^{213,218}$. Given that MMP9 is known to exert proteolytic activity on various ECM components ${ }^{219}$, chymase could thus indirectly promote the degradation of ECM and thereby contribute to anti-fibrotic mechanisms. Chymase has also been reported to activate pro-collagenase ${ }^{220}$, thereby providing a mechanism for collagen degradation and amelioration of fibrosis. Another example is the reported ability of tryptase to activate pro-MMP3 and pro-MMP13 ${ }^{221,222}$. As active MMP3 and MMP13 are known to 
degrade a number of ECM components such as collagen, proteoglycans and fibronectin ${ }^{223}$, it is possible that tryptase thereby could exert anti-fibrotic activity.

A notable example of direct effects of the MC proteases on ECM compounds is the ability of chymase to degrade fibronectin. This has been verified both in purified systems ${ }^{224}$, in cell culture settings ${ }^{214}$ and also in vivo ${ }^{212,213}$. The collective evidence from these studies suggests that fibronectin is an exceptionally good substrate for chymase, most likely being a preferred target for this protease in vivo ${ }^{225}$. Another example of direct effects of MC proteases on ECM components is the ability of tryptase to degrade denatured collagen (gelatin) ${ }^{226}$, which could serve possibly to reduce fibrotic lesions.

\section{Targeting mast cell function in fibrosis}

\section{- Inhibitors of protease activity}

Based on the hypothesis that chymase contributes to the development of fibrotic lesions, investigators have sought to interfere with fibrosis by administrating various chymase inhibitors. Indeed, the chymase inhibitors SUN-C8077, BCEAB and NK3201 reduced bleomycin-induced lung fibrosis in separate studies ${ }^{227-229}$. Mechanistically, it was shown that chymase inhibition led to a decrease in the content of TGF $\beta$ and MMP2 in the lungs, and it was demonstrated that chymase inhibition prevented effects of endothelin-1. The latter observation is thus in agreement with a previous study where chymase was shown to be pivotal for the conversion of Big-endothelin-1 to endothelin- ${ }^{230}$. Chymase inhibition (using TY-51469) has also been shown to dampen liver fibrosis in hamsters fed on a methionineand choline-deficient diet, and it was demonstrated that chymase inhibition attenuated the induction of angiotensin II and collagen expression in comparison with placebo-treated animals ${ }^{231}$. In addition, chymase inhibition using various compounds has been demonstrated 
to reduce cardiac fibrosis and Ang II production diabetic hamsters ${ }^{232}$, cardiac fibrosis after ischemia reperfusion injury ${ }^{233}$, silica-induced pulmonary fibrosis in mice ${ }^{234}, \mathrm{CCl}_{4}$-induced liver fibrosis in hamsters ${ }^{235}$, tubulointerstitial fibrosis in obstructed kidneys in hamsters ${ }^{236}$, cardiac fibrosis in rats subjected to ligation of the left anterior descending coronary artery ${ }^{237}$, cardiac fibrosis in cardiomyopathic hamsters ${ }^{238}$ and cardiac fibrosis in dogs subjected to tachycardia-induced heart failure ${ }^{239}$.

As a pharmacological approach to address the role of tryptase in fibrotic conditions in vivo, Li et al. ${ }^{240}$ induced cardiac fibrosis in rats by transverse aortic constriction and treated the animals with a selective tryptase inhibitor (nafamostat mesylate). It was found that tryptase inhibition led to ameliorated cardiac fibrosis, in line with a pro-fibrotic impact of MC tryptase. In agreement with these findings, tryptase inhibition by administrating another compound (APC-366) was shown to dampen the bile duct ligation-induced liver fibrosis in rats ${ }^{241}$. The pharmacological approaches used to study the role of mast cells in animal models of fibrosis are summarised in Table 5.

\section{- Other pharmacological approaches to target mast cells in fibrosis}

In addition to targeting specific mediators, there are several other aspects of MC biology potentially suitable for pharmacological targeting (Figure 4). However, to develop these it will be important to understand the mechanisms by which fibroblasts and other cells activate MCs in fibrotic tissues.

The traditional approach commonly perceived to prevent MC activation in disease has been the use of drugs labelled as "MC stabilising agents" such as disodium cromoglycate. In a model of 2,4,6,-trinitrobenzene sulfonic acid-induced colitis, $\mathrm{Xu}$ et al. demonstrated that nedocromil, a cromoglycate derivative, reduced the extent of fibrosis ${ }^{242}$. Nedocromil has also been demonstrated to ameliorate left ventricular fibrosis in spontaneously hypertensive rats 
${ }^{243}$ and to reduce cardiac fibrosis resulting from transverse aortic constriction ${ }^{240}$. Another MC "stabiliser", Tranilast, reduced the extent of experimentally induced fibrosis in mice ${ }^{180}$. However, Tranilast was equally efficient in MC-competent versus -deficient mice ${ }^{180}$, suggesting that the impact of Tranilast was not due to effects mediated by MCs. In addition, Tranilast was shown to be without effect against fibrosis in rats with chronic renal failure ${ }^{244}$. In a study by Palaniyandi Selvaraj et al., it was demonstrated that disodium cromoglycate reduced the fibrosis during autoimmune myocarditis ${ }^{197}$, and this compound also reduced atrial fibrosis occurring after pressure overload in a mouse model ${ }^{199}$, fibrosis after implantation of biomaterials ${ }^{194}$, kidney fibrosis in the unilateral ureteral obstruction model ${ }^{188,191}$ and the development of liver fibrosis in multidrug resistance 2 knockout mice ${ }^{245}$. However, since cromoglycate has been shown to have effects outside of its impact on MCs ${ }^{246}$, it is not certain that effects of this compound are mediated through MCs as opposed to other targets. MC inhibition by ketitofen has also been shown to ameliorate fibrosis in a pig model ${ }^{247}$ and joint capsule fibrosis in a rabbit model ${ }^{248}$.

In human disease, cromoglycate is used with some efficacy in rhino-conjunctivitis and perhaps asthma, but it is a weak inhibitor of human lung MCs, and demonstrates rapid tachyphylaxis ${ }^{249-251}$. It is therefore unlikely to be helpful in the treatment of lung fibrosis. Beta-2 adrenergic receptor ( $\beta 2-\mathrm{AR})$ agonists are currently one of the most commonly used treatments in asthma. $\beta 2-\mathrm{AR}$ agonists are more potent at inhibiting FceRI-dependent MC activation than disodium cromoglycate in vitro, but human lung MCs demonstrate rapid functional desensitisation of the $\beta 2-A R{ }^{252}$. $\beta 2$-AR agonists have been proposed as a treatment for fibrosis ${ }^{253}$, but activation of RTKs including Kit uncouples $\beta 2$-ARs ${ }^{254,255}$. In fact, $\beta 2-\mathrm{AR}$ agonists increased human lung $\mathrm{MC}$ mediator release in co-culture with human ASM cells ${ }^{256}$, so it is possible that in the lung, $\beta 2$-AR agonists might make fibrosis worse. Thus more effective inhibitors of MC activation are required. 
Alternative targets for preventing MC activation in human lung disease are emerging. In humans and mice, the intermediate conductance $\mathrm{Ca}^{2+}$-activated $\mathrm{K}^{+}$channel $\mathrm{K}_{\mathrm{Ca}} 3.1$ is activated following FceRI-dependent activation ${ }^{257,258}$. These channels support human lung MC influx of $\mathrm{Ca}^{2+}$ via Orai 1 channels ${ }^{259}$, and thus enhance the activation-dependent influx of $\mathrm{Ca}^{2+}$ and histamine release in both human lung MCs and mice ${ }^{258,260}$. Blockers of $\mathrm{K}_{\mathrm{Ca}} 3.1$ are available, and ICA-17043 (Senicapoc) has proved safe in phase III clinical trials for sickle cell disease and attenuated pulmonary fibrosis a sheep model ${ }^{261}$. This drug is also very effective at inhibiting pro-fibrotic human lung myofibroblast activity ${ }^{31,111,262}$ and epithelialmesenchymal transition ${ }^{263}$, so $\mathrm{K}_{\mathrm{Ca}} 3.1$ is becoming a highly attractive target for the treatment of fibrosis in several tissues including, lung ${ }^{111,261}$, liver ${ }^{264,265}$, kidney ${ }^{265-267}$, and heart ${ }^{268-273}$.

Kit and SCF are also obvious targets. This approach has the potential to target pathological interactions between MCs and airway structural cells mediated by membrane bound Kit which is likely to be important in pulmonary fibrosis. A recent study of the Kit inhibitor imatinib in severe asthma suggested that it exerts biological effects on MCs in the lung although the clinical effects were limited, and side effects limited treatment ${ }^{274}$. Masitinib, another tyrosine kinase inhibitor targeting Kit signalling may also have some efficacy in severe asthma ${ }^{275}$. There is therefore a strong rationale for trialling these in IPF.

Inhibition of MC adhesion to fibroblasts may also be an attractive therapeutic approach. CADM1 plays a central role in the interaction of MCs with fibroblasts ${ }^{138}$, regulating MC survival and proliferation, and CADM1 has been implicated in the development of fibrosis 166,276. CADM1 is also a tumour suppressor in epithelial cells, so targeting would need to be MC-selective. To achieve this, future work should focus on understanding the intracellular signalling pathways connected to CADM1 in MCs and other cells, and the isoforms of CADM1 expressed. 


\section{Are mast cells fibrotic or anti-fibrotic?}

There is clearly much discrepancy in the results above with both pro-fibrotic and anti-fibrotic roles for MCs described. The human clinical data and in vitro data lean towards a pro-fibrotic role for mast cells, while the animal models manipulating mast cell numbers are inconsistent. Animal models inhibiting chymase in particular suggest that this protease plays a pro-fibrotic role, in keeping with the predominance of NCTC MCs in human fibrotic lesions.

There are likely to be several reasons for these discrepant results. We believe a major reason for this is that the aim of resident tissue MCs is to sense injury and then initiate a coordinated program of injury and repair. When this scenario is allowed to progress naturally, and the injurious stimulus is short-lived, then MCs will overall exert anti-fibrotic activity. This is undoubtedly behind the potentially anti-fibrotic activity evident in some short-term animal models. In contrast, when the injurious stimulus is chronic or repeated, then there is great potential for the vast armamentarium of pro-fibrotic MC mediators that are released on a minute-by-minute basis to do harm and lead to tissue fibrosis (Figure 5). This seems particularly relevant to human fibrotic diseases which often progress over many years, and is a very different scenario to the short term animal models. The human clinical data associating activated MCs with the progression and severity of fibrosis, the overall pro-fibrotic cross-talk between human MCs and fibroblasts in co-culture, and knowledge that many human MCderived mediators exert pro-fibrotic effects on human fibroblasts, support this conclusion.

There are without doubt further biological and technical reasons for discrepancies between animal studies, and between human and animal data. These include species and tissuedependent heterogeneity in MCs and fibroblast biology, and differences in MC numbers and location in mice versus humans; healthy human lung contains numerous MCs whereas these are relatively sparse in healthy mouse lungs. Differences in the animal protocols are also 
likely to be very important, for example, mild versus harsh conditions and an acute versus chronic stimulus. Bleomycin lung injury for example is characterised by an initial phase of severe inflammation followed by reversible fibrosis, which is very different to the pathology of human IPF.

\section{Future directions}

For further research, we believe it will be important to assess the new generation of MCdeficient mice (non-kit-dependent) in various models of fibrosis. Using more subtle longer term stimuli may be far more informative than the acute inflammatory stimulus delivered by bleomycin for example. More studies on MC protease knockout animals in models of fibrosis will be helpful, in particular tryptase knockouts, considering that many studies implicate tryptase in fibrosis.

Targeting MCs in tissue fibrosis remains an important goal but a major challenge. The diversity and heterogeneity of MC mediators and the multiple mechanisms of MC activation may have important therapeutic implications, and yet we know relatively little about these. Furthermore, different modes of MC activation may be important during different phases of the natural history of a long term fibrotic process, so that treatment effective at an early phase, may not be so effective later. However, our final opinion is that novel therapeutic agents that are able to target pro-fibrotic pathways involving MCs are likely to be effective in many chronic fibrotic disease processes. 


\section{REFERENCES}

1. Wynn TA, Ramalingam TR. Mechanisms of fibrosis: therapeutic translation for fibrotic disease. Nat Med 2012;18:1028-1040.

2. McAnulty RJ. Fibroblasts and myofibroblasts: their source, function and role in disease. Int J Biochem Cell Biol 2007;39:666-671.

3. Bradding P, Arthur G. Mast cells in asthma--state of the art. Clin Exp Allergy 2016;46:194-263.

4. Wernersson S, Pejler G. Mast cell secretory granules: armed for battle. Nat Rev Immunol 2014;14:478-494.

5. Akahoshi M, Song CH, Piliponsky AM, et al. Mast cell chymase reduces the toxicity of Gila monster venom, scorpion venom, and vasoactive intestinal polypeptide in mice. J Clin Invest 2011.

6. Malaviya R, Ikeda T, Ross E, Abraham SN. Mast cell modulation of neutrophil influx and bacterial clearance at sites of infection through TNF-alpha. Nature 1996;381:7780 .

7. Gotis-Graham I, McNeil HP. Mast cell responses in rheumatoid synovium. Association of the MCTC subset with matrix turnover and clinical progression. Arthritis Rheum 1997;40:479-489.

8. Skrabal CA, Thompson LO, Southard RE, et al. Interaction between isolated human myocardial mast cells and cultured fibroblasts. J Surg Res 2004;118:66-70.

9. Fairweather D, Frisancho-Kiss S. Mast cells and inflammatory heart disease: potential drug targets. Cardiovasc Hematol Disord Drug Targets 2008;8:80-90.

10. Welsh G, Green RH, Richardson D, Waller DA, O'Byrne KJ, Bradding P. Macrophage and mast cell invasion of tumour cell islets confers a marked survival advantage in non-small-cell lung cancer. J Clin Oncol 2005;23:8959-8967.

11. Galdiero MR, Varricchi G, Marone G. The immune network in thyroid cancer. Oncoimmunology 2016;5:e1168556.

12. Ehara T, Shigematsu H. Mast cells in the kidney. Nephrology (Carlton) 2003;8:130138.

13. King TE, Jr., Pardo A, Selman M. Idiopathic pulmonary fibrosis. Lancet 2011;378:1949-1961.

14. Gribbin J, Hubbard RB, Le J, I, Smith CJ, West J, Tata LJ. Incidence and mortality of idiopathic pulmonary fibrosis and sarcoidosis in the UK. Thorax 2006;61:980-985.

15. Raghu G, Weycker D, Edelsberg J, Bradford WZ, Oster G. Incidence and prevalence of idiopathic pulmonary fibrosis. Am J Respir Crit Care Med 2006;174:810-816. 
16. Navaratnam V, Fleming KM, West $\mathrm{J}$, et al. The rising incidence of idiopathic pulmonary fibrosis in the U.K. Thorax 2011;66:462-467.

17. Noble PW, Albera C, Bradford WZ, et al. Pirfenidone in patients with idiopathic pulmonary fibrosis (CAPACITY): two randomised trials. Lancet 2011;377:17601769.

18. Richeldi L, du Bois RM, Raghu G, et al. Efficacy and safety of nintedanib in idiopathic pulmonary fibrosis. N Engl J Med 2014;370:2071-2082.

19. Strieter RM. Pathogenesis and natural history of usual interstitial pneumonia: the whole story or the last chapter of a long novel. Chest 2005;128:526S-532S.

20. Khalil $\mathrm{N}$, O'Connor $\mathrm{RN}$, Unruh $\mathrm{HW}$, et al. Increased production and immunohistochemical localization of transforming growth factor-beta in idiopathic pulmonary fibrosis. Am J Respir Cell Mol Biol 1991;5:155-162.

21. Xu YD, Hua J, Mui A, O'Connor R, Grotendorst G, Khalil N. Release of biologically active TGF-beta1 by alveolar epithelial cells results in pulmonary fibrosis. Am J Physiol Lung Cell Mol Physiol 2003;285:L527-L539.

22. Tarantal AF, Chen H, Shi TT, et al. Overexpression of transforming growth factorbeta1 in fetal monkey lung results in prenatal pulmonary fibrosis. Eur Respir J 2010;36:907-914.

23. Goodwin A, Jenkins G. Role of integrin-mediated TGFbeta activation in the pathogenesis of pulmonary fibrosis. Biochem Soc Trans 2009;37:849-854.

24. Gharaee-Kermani M, Hu B, Phan SH, Gyetko MR. Recent advances in molecular targets and treatment of idiopathic pulmonary fibrosis: focus on TGFbeta signaling and the myofibroblast. Curr Med Chem 2009;16:1400-1417.

25. Inoue Y, King TEJ, Tinkle SS, Dockstader K, Newman LS. Human mast cell basic fibroblast growth factor in pulmonary fibrotic disorders. Am J Pathol 1996;149:20372054.

26. Huaux F, Liu T, McGarry B, Ullenbruch M, Phan SH. Dual roles of IL-4 in lung injury and fibrosis. J Immunol 2003;170:2083-2092.

27. Fichtner-Feigl S, Strober W, Kawakami K, Puri RK, Kitani A. IL-13 signaling through the IL-13alpha2 receptor is involved in induction of TGF-beta1 production and fibrosis. Nat Med 2006;12:99-106.

28. Wollin L, Wex E, Pautsch A, et al. Mode of action of nintedanib in the treatment of idiopathic pulmonary fibrosis. Eur Respir J 2015;45:1434-1445.

29. Wynn TA. Cellular and molecular mechanisms of fibrosis. J Pathol 2008;214:199210.

30. Scotton CJ, Chambers RC. Molecular targets in pulmonary fibrosis: the myofibroblast in focus. Chest 2007;132:1311-1321. 
31. Roach KM, Wulff H, Feghali-Bostwick C, Amrani Y, Bradding P. Increased constitutive alphaSMA and Smad2/3 expression in idiopathic pulmonary fibrosis myofibroblasts is KCa3.1-dependent. Respir Res 2014;15:155.

32. Torry DJ, Richards CD, Podor TJ, Gauldie J. Anchorage-independent colony growth of pulmonary fibroblasts derived from fibrotic human lung tissue. J Clin Invest 1994;93:1525-1532.

33. Suganuma H, Sato A, Tamura R, Chida K. Enhanced migration of fibroblasts derived from lungs with fibrotic lesions. Thorax 1995;50:984-989.

34. Miki H, Mio T, Nagai S, et al. Fibroblast contractility: usual interstitial pneumonia and nonspecific interstitial pneumonia. Am J Respir Crit Care Med 2000;162:22592264.

35. Shoda H, Yokoyama A, Nishino R, et al. Overproduction of collagen and diminished SOCS1 expression are causally linked in fibroblasts from idiopathic pulmonary fibrosis. Biochem Biophys Res Commun 2007;353:1004-1010.

36. Wilborn J, Crofford LJ, Burdick MD, Kunkel SL, Strieter RM, Peters-Golden M. Cultured lung fibroblasts isolated from patients with idiopathic pulmonary fibrosis have a diminished capacity to synthesize prostaglandin E2 and to express cyclooxygenase-2. J Clin Invest 1995;95:1861-1868.

37. Duffy SM, Cruse G, Cockerill SL, Brightling CE, Bradding P. Engagement of the $\mathrm{EP}_{2}$ prostanoid receptor closes the $\mathrm{K}^{+}$channel $\mathrm{K}_{\mathrm{Ca}} 3.1$ in human lung mast cells and attenuates their migration. Eur J Immunol 2008;38:2548-2556.

38. Kawanami O, Ferrans VJ, Fulmer JD, Crystal RG. Ultrastructure of pulmonary mast cells in patients with fibrotic lung disorders. Lab Invest 1979;40:717-734.

39. Inoue Y, King TE, Jr., Barker E, Daniloff E, Newman LS. Basic fibroblast growth factor and its receptors in idiopathic pulmonary fibrosis and lymphangioleiomyomatosis. Am J Respir Crit Care Med 2002;166:765-773.

40. Groot KT, Pardo A, Knipping K, et al. Immunoglobulin free light chains are increased in hypersensitivity pneumonitis and idiopathic pulmonary fibrosis. PLoS One 2011;6:e25392.

41. Hirata K, Sugama Y, Ikura Y, et al. Enhanced mast cell chymase expression in human idiopathic interstitial pneumonia. Int J Mol Med 2007;19:565-570.

42. Wygrecka M, Dahal BK, Kosanovic D, et al. Mast Cells and Fibroblasts Work in Concert to Aggravate Pulmonary Fibrosis: Role of Transmembrane SCF and the PAR-2/PKC-alpha/Raf-1/p44/42 Signaling Pathway. Am J Pathol 2013.

43. Haslam PL, Cromwell O, Dewar A, Turner-Warwick M. Evidence of increased histamine levels of lung lavage fluids from patients with cryptogenic fibrosing alveolitis. Clin Exp Immunol 1981;44:587-593.

44. Pesci A, Bertorelli G, Gabrielli M, Olivieri D. Mast cells in fibrotic lung disorders. Chest 1993;103:989-996. 
45. Hunt LW, Colby TV, Weiler DA, Sur S, Butterfield JH. Immunofluorescent staining for mast cells in idiopathic pulmonary fibrosis: quantification and evidence for extracellular release of mast cell tryptase. Mayo Clin Proc 1992;67:941-948.

46. Walls AF, Bennett AR, Godfrey RC, Holgate ST, Church MK. Mast cell tryptase and histamine concentrations in bronchoalveolar lavage fluid from patients with interstitial lung disease. Clin Sci (Lond) 1991;81:183-188.

47. Chanez P, Lacoste JY, Guillot B, et al. Mast cells' contribution to the fibrosing alveolitis of the scleroderma lung. Am Rev Respir Dis 1993;147:1497-1502.

48. Hamada H, Vallyathan V, Cool CD, Barker E, Inoue Y, Newman LS. Mast cell basic fibroblast growth factor in silicosis. Am J Respir Crit Care Med 2000;161:2026-2034.

49. Lyle RE, Tryka AF, Griffin WS, Taylor BJ. Tryptase immunoreactive mast cell hyperplasia in bronchopulmonary dysplasia. Pediatr Pulmonol 1995;19:336-343.

50. Casale TB, Trapp S, Zehr B, Hunninghake GW. Bronchoalveolar lavage fluid histamine levels in interstitial lung diseases. Am Rev Respir Dis 1988;138:1604-1608.

51. Rankin JA, Kaliner M, Reynolds HY. Histamine levels in bronchoalveolar lavage from patients with asthma, sarcoidosis, and idiopathic pulmonary fibrosis. J Allergy Clin Immunol 1987;79:371-377.

52. Agius RM, Godfrey RC, Holgate ST. Mast cell and histamine content of human bronchoalveolar lavage fluid. Thorax 1985;40:760-767.

53. Soler $\mathrm{P}$, Nioche $\mathrm{S}$, Valeyre $\mathrm{D}$, et al. Role of mast cells in the pathogenesis of hypersensitivity pneumonitis. Thorax 1987;42:565-572.

54. Bjermer L, Engstrom-Laurent A, Thunell M, Hallgren R. Hyaluronic acid in bronchoalveolar lavage fluid in patients with sarcoidosis: relationship to lavage mast cells. Thorax 1987;42:933-938.

55. Bjermer L, Engstrom-Laurent A, Lundgren R, Rosenhall L, Hallgren R. Bronchoalveolar mastocytosis in farmer's lung is related to the disease activity. Arch Intern Med 1988;148:1362-1365.

56. Bjermer L, Rosenhall L, Angstrom T, Hallgren R. Predictive value of bronchoalveolar lavage cell analysis in sarcoidosis. Thorax 1988;43:284-288.

57. Haslam PL, Dewar A, Butchers P, Primett ZS, Newman-Taylor A, Turner-Warwick M. Mast cells, atypical lymphocytes, and neutrophils in bronchoalveolar lavage in extrinsic allergic alveolitis. Comparison with other interstitial lung diseases. Am Rev Respir Dis 1987;135:35-47.

58. Andersson CK, Andersson-Sjoland A, Mori M, et al. Activated MCTC mast cells infiltrate diseased lung areas in cystic fibrosis and idiopathic pulmonary fibrosis. Respir Res 2011;12:139. 
59. Heard BE, Dewar A, Corrin B. Apposition of fibroblasts to mast cells and lymphocytes in normal human lung and in cryptogenic fibrosing alveolitis. Ultrastructure and cell perimeter measurements. J Pathol 1992;166:303-310.

60. Bradding P, Okayama Y, Howarth PH, Church MK, Holgate, ST. Heterogeneity of human mast cells based on cytokine content. J Immunol 1995;155:297-307.

61. Kanbe N, Kurosawa M, Nagata H, Yamashita T, Kurimoto F, Miyachi Y. Production of fibrogenic cytokines by cord blood-derived cultured human mast cells. J Allergy Clin Immunol 2000;106:S85-S90.

62. Qu Z, Liebler JM, Powers MR, et al. Mast cells are a major source of basic fibroblast growth factor in chronic inflammation and cutaneous hemangioma. Am J Pathol 1995; $147: 564-573$.

63. Reed JA, Albino AP, McNutt NS. Human cutaneous mast cells express basic fibroblast growth factor. Lab Invest 1995;72:215-222.

64. Andersson CK, Mori M, Bjermer L, Lofdahl CG, Erjefalt JS. Novel site-specific mast cell subpopulations in the human lung. Thorax 2009;64:297-305.

65. Hill NR, Fatoba ST, Oke JL, et al. Global Prevalence of Chronic Kidney Disease - A Systematic Review and Meta-Analysis. PLoS One 2016;11:e0158765.

66. Madjene LC, Pons M, Danelli L, et al. Mast cells in renal inflammation and fibrosis: lessons learnt from animal studies. Mol Immunol 2015;63:86-93.

67. Webster AC, Nagler EV, Morton RL, Masson P. Chronic Kidney Disease. Lancet 2017;389:1238-1252.

68. Tan RJ, Zhou D, Liu Y. Signaling Crosstalk between Tubular Epithelial Cells and Interstitial Fibroblasts after Kidney Injury. Kidney Dis (Basel) 2016;2:136-144.

69. Toth T, Toth-Jakatics R, Jimi S, Ihara M, Urata H, Takebayashi S. Mast cells in rapidly progressive glomerulonephritis. J Am Soc Nephrol 1999;10:1498-1505.

70. Roberts IS, Brenchley PE. Mast cells: the forgotten cells of renal fibrosis. J Clin Pathol 2000;53:858-862.

71. El-Koraie AF, Baddour NM, Adam AG, El Kashef EH, El Nahas AM. Role of stem cell factor and mast cells in the progression of chronic glomerulonephritides. Kidney Int 2001;60:167-172.

72. Hiromura K, Kurosawa M, Yano S, Naruse T. Tubulointerstitial mast cell infiltration in glomerulonephritis. Am J Kidney Dis 1998;32:593-599.

73. Kondo S, Kagami S, Kido H, Strutz F, Muller GA, Kuroda Y. Role of mast cell tryptase in renal interstitial fibrosis. J Am Soc Nephrol 2001;12:1668-1676.

74. Ehara T, Shigematsu H. Contribution of mast cells to the tubulointerstitial lesions in IgA nephritis. Kidney Int 1998;54:1675-1683. 
75. Kurusu A, Suzuki Y, Horikoshi S, Shirato I, Tomino Y. Relationship between mast cells in the tubulointerstitium and prognosis of patients with $\operatorname{IgA}$ nephropathy. Nephron 2001;89:391-397.

76. Welker P, Kramer S, Groneberg DA, et al. Increased mast cell number in human hypertensive nephropathy. Am J Physiol Renal Physiol 2008;295:F1103-F1109.

77. Toth T, Toth-Jakatics R, Jimi S, Takebayashi S. Increased density of interstitial mast cells in amyloid A renal amyloidosis. Mod Pathol 2000;13:1020-1028.

78. Pardo J, Diaz L, Errasti P, et al. Mast cells in chronic rejection of human renal allografts. Virchows Arch 2000;437:167-172.

79. Yamada M, Ueda M, Naruko T, et al. Mast cell chymase expression and mast cell phenotypes in human rejected kidneys. Kidney Int 2001;59:1374-1381.

80. Abo-Zenah H, Katsoudas S, Wild G, et al. Early human renal allograft fibrosis: cellular mediators. Nephron 2002;91:112-119.

81. Ishida T, Hyodo Y, Ishimura T, Takeda M, Hara I, Fujisawa M. Mast cell numbers and protease expression patterns in biopsy specimens following renal transplantation from living-related donors predict long-term graft function. Clin Transplant 2005;19:817-824.

82. Grandaliano G, Pontrelli P, Cerullo G, et al. Protease-activated receptor-2 expression in IgA nephropathy: a potential role in the pathogenesis of interstitial fibrosis. $J \mathrm{Am}$ Soc Nephrol 2003;14:2072-2083.

83. Irani AA, Schechter NM, Craig SS, DeBlois G, Schwartz, LB. Two types of human mast cells that have distinct neutral protease compositions. Proc Natl Acad Sci USA 1986;83:4464-4468.

84. Hawkins RA, Claman HN, Clark RA, Steigerwald JC. Increased dermal mast cell populations in progressive systemic sclerosis: a link in chronic fibrosis? Ann Intern Med 1985;102:182-186.

85. Nishioka K, Kobayashi Y, Katayama I, Takijiri C. Mast cell numbers in diffuse scleroderma. Arch Dermatol 1987;123:205-208.

86. Akimoto S, Ishikawa O, Igarashi Y, Kurosawa M, Miyachi Y. Dermal mast cells in scleroderma: their skin density, tryptase/chymase phenotypes and degranulation. $\mathrm{Br} J$ Dermatol 1998;138:399-406.

87. Irani AM, Gruber BL, Kaufman LD, Kahaleh MB, Schwartz LB. Mast cell changes in scleroderma. Presence of MCT cells in the skin and evidence of mast cell activation. Arthritis Rheum 1992;35:933-939.

88. Seibold JR, Giorno RC, Claman HN. Dermal mast cell degranulation in systemic sclerosis. Arthritis \& Rheumatism 1990;33:1702-1709.

89. Falanga V, Soter NA, Altman RD, Kerdel FA. Elevated plasma histamine levels in systemic sclerosis (scleroderma). Arch Dermatol 1990;126:336-338. 
90. Hugle T, Hogan V, White KE, van Laar JM. Mast cells are a source of transforming growth factor beta in systemic sclerosis. Arthritis Rheum 2011;63:795-799.

91. Hugle T, White K, van Laar JM. Cell-to-cell contact of activated mast cells with fibroblasts and lymphocytes in systemic sclerosis. Ann Rheum Dis 2012;71:1582.

92. Kong P, Christia P, Frangogiannis NG. The pathogenesis of cardiac fibrosis. Cell Mol Life Sci 2014;71:549-574.

93. Patella V, Marino I, Lamparter B, Arbustini E, Adt M, Marone G. Human heart mast cells. Isolation, purification, ultrastructure, and immunologic characterization. $J$ Immunol 1995; 154:2855-2865.

94. Sperr WR, Bankl HC, Mundigler G, et al. The human cardiac mast cell: localization, isolation, phenotype, and functional characterization. Blood 1994;84:3876-3884.

95. Li QY, Raza-Ahmad A, MacAulay MA, et al. The relationship of mast cells and their secreted products to the volume of fibrosis in posttransplant hearts. Transplantation 1992;53:1047-1051.

96. Patella V, Marino I, Arbustini E, et al. Stem cell factor in mast cells and increased mast cell density in idiopathic and ischemic cardiomyopathy. Circulation 1998;97:971-978.

97. Zhang S, Anderson DF, Bradding P, et al. Human mast cells express stem cell factor. J Pathol 1998;186:59-66.

98. Batlle M, Perez-Villa F, Lazaro A, et al. Correlation between mast cell density and myocardial fibrosis in congestive heart failure patients. Transplant Proc 2007;39:2347-2349.

99. Akgul A, Skrabal CA, Thompson LO, et al. Role of mast cells and their mediators in failing myocardium under mechanical ventricular support. J Heart Lung Transplant 2004;23:709-715.

100. Hernandez-Gea V, Friedman SL. Pathogenesis of liver fibrosis. Annu Rev Pathol 2011;6:425-456.

101. Farrell DJ, Hines JE, Walls AF, Kelly PJ, Bennett MK, Burt AD. Intrahepatic mast cells in chronic liver diseases. Hepatology 1995;22:1175-1181.

102. Armbrust T, Batusic D, Ringe B, Ramadori G. Mast cells distribution in human liver disease and experimental rat liver fibrosis. Indications for mast cell participation in development of liver fibrosis. J Hepatol 1997;26:1042-1054.

103. Shimizu S, Satomura K, Aramaki T, Katsuta Y, Takano T, Omoto Y. Hepatic chymase level in chronic hepatitis: co-localization of chymase with fibrosis. Hepatol Res 2003;27:62-66.

104. Yamashiro M, Kouda W, Kono N, Tsuneyama K, Matsui O, Nakanuma Y. Distribution of intrahepatic mast cells in various hepatobiliary disorders. An immunohistochemical study. Virchows Arch 1998;433:471-479. 
105. Matsunaga Y, Kawasaki H, Terada T. Stromal mast cells and nerve fibers in various chronic liver diseases: relevance to hepatic fibrosis. Am $J$ Gastroenterol 1999;94:1923-1932.

106. Satomura K, Yin M, Shimizu S, et al. Increased chymase in livers with autoimmune disease: colocalization with fibrosis. J Nippon Med Sch 2003;70:490-495.

107. Gittlen SD, Schulman ES, Maddrey WC. Raised histamine concentrations in chronic cholestatic liver disease. Gut 1990;31:96-99.

108. Quist RG, Ton-Nu HT, Lillienau J, Hofmann AF, Barrett KE. Activation of mast cells by bile acids. Gastroenterology 1991;101:446-456.

109. Boucek RJ, Noble NL. Histamine, norepinephrine, and bradykinin stimulation of fibroblast growth and modification of serotonin response. Proc Soc Exp Biol Med 1973;144:929-933.

110. Jordana M, Befus AD, Newhouse MT, Bienenstock J, Gauldie, J. Effect of histamine on proliferation of normal human adult lung fibroblasts. Thorax 1988;43:552-558.

111. Roach KM, Duffy SM, Coward W, Feghali-Bostwick C, Wulff H, Bradding P. The $\mathrm{K}(+)$ Channel KCa3.1 as a Novel Target for Idiopathic Pulmonary Fibrosis. PLoS One 2013;8:e85244.

112. Hetzel M, Bachem M, Anders D, Trischler G, Faehling M. Different effects of growth factors on proliferation and matrix production of normal and fibrotic human lung fibroblasts. Lung 2005;183:225-237.

113. Postlethwaite AE, Seyer JM. Stimulation of fibroblast chemotaxis by human recombinant tumor necrosis factor alpha (TNF-alpha) and a synthetic TNF-alpha 3168 peptide. J Exp Med 1990;172:1749-1756.

114. Dayer JM, Beutler B, Cerami A. Cachectin/tumor necrosis factor stimulates collagenase and prostaglandin E2 production by human synovial cells and dermal fibroblasts. J Exp Med 1985;162:2163-2168.

115. Postlethwaite AE, Seyer JM. Fibroblast chemotaxis induction by human recombinant interleukin- 4. Identification by synthetic peptide analysis of two chemotactic domains residing in amino acid sequences 70-88 and 89- 122. J Clin Invest 1991;87:2147-2152.

116. Feghali CA, Bost KL, Boulware DW, Levy LS. Human recombinant interleukin-4 induces proliferation and interleukin-6 production by cultured human skin fibroblasts. Clin Immunol Immunopathol 1992;63:182-187.

117. Trautmann A, Krohne G, Brocker EB, Klein CE. Human mast cells augment fibroblast proliferation by heterotypic cell-cell adhesion and action of IL-4. J Immunol 1998;160:5053-5057.

118. Doucet C, Brouty-Boye D, Pottin-Clemenceau C, Canonica GW, Jasmin C, Azzarone B. Interleukin (IL) 4 and IL-13 act on human lung fibroblasts. Implication in asthma. J Clin Invest 1998;101:2129-2139. 
119. Postlethwaite AE, Holness MA, Katai H, Raghow R. Human fibroblasts synthesize elevated levels of extracellular matrix proteins in response to interleukin 4. J Clin Invest 1992;90:1479-1485.

120. Andrews AL, Nasir T, Bucchieri F, Holloway JW, Holgate ST, Davies DE. IL-13 receptor alpha 2: a regulator of IL-13 and IL-4 signal transduction in primary human fibroblasts. J Allergy Clin Immunol 2006;118:858-865.

121. Doucet C, Brouty-Boye D, Pottin-Clemenceau C, Jasmin C, Canonica GW, Azzarone B. IL-4 and IL-13 specifically increase adhesion molecule and inflammatory cytokine expression in human lung fibroblasts. Int Immunol 1998;10:1421-1433.

122. Kraft M, Lewis C, Pham D, Chu HW. IL-4, IL-13, and dexamethasone augment fibroblast proliferation in asthma. J Allergy Clin Immunol 2001;107:602-606.

123. Fuschiotti P, Larregina AT, Ho J, Feghali-Bostwick C, Medsger TA, Jr. Interleukin13-producing CD8+ $\mathrm{T}$ cells mediate dermal fibrosis in patients with systemic sclerosis. Arthritis Rheum 2013;65:236-246.

124. Gospodarowicz D, Cheng J. Heparin protects basic and acidic FGF from inactivation. J Cell Physiol 1986;128:475-484.

125. Yayon A, Klagsbrun M, Esko JD, Leder P, Ornitz DM. Cell surface, heparin-like molecules are required for binding of basic fibroblast growth factor to its high affinity receptor. Cell 1991;64:841-848.

126. Woodman L, Siddiqui S, Cruse G, et al. Mast Cells Promote Airway Smooth Muscle Cell Differentiation via Autocrine Up-Regulation of TGF-\{beta\}1. J Immunol 2008;181:5001-5007.

127. Gailit J, Marchese MJ, Kew RR, Gruber BL. The differentiation and function of myofibroblasts is regulated by mast cell mediators. J Invest Dermatol 2001;117:11131119.

128. Enomoto Y, Orihara K, Takamasu T, et al. Tissue remodeling induced by hypersecreted epidermal growth factor and amphiregulin in the airway after an acute asthma attack. J Allergy Clin Immunol 2009;124:913-920.

129. Abe M, Kurosawa M, Ishikawa O, Miyachi Y. Effect of mast cell-derived mediators and mast cell-related neutral proteases on human dermal fibroblast proliferation and type I collagen production. J Allergy Clin Immunol 2000;106:S78-S84.

130. Cairns JA, Walls AF. Mast cell tryptase stimulates the synthesis of type I collagen in human lung fibroblasts. J Clin Invest 1997;99:1313-1321.

131. Gruber BL, Kew RR, Jelaska A, et al. Human mast cells activate fibroblasts: tryptase is a fibrogenic factor stimulating collagen messenger ribonucleic acid synthesis and fibroblast chemotaxis. J Immunol 1997;158:2310-2317.

132. Frungieri MB, Weidinger S, Meineke V, Kohn FM, Mayerhofer A. Proliferative action of mast-cell tryptase is mediated by PAR2, COX2, prostaglandins, and 
PPARgamma : Possible relevance to human fibrotic disorders. Proc Natl Acad Sci U $S$ A 2002;99:15072-15077.

133. Greenberg G, Burnstock G. A novel cell-to-cell interaction between mast cells and other cell types. Exp Cell Res 1983;147:1-13.

134. Subba Rao PV, Friedman MM, Atkins FM, Metcalfe DD. Phagocytosis of mast cell granules by cultured fibroblasts. J Immunol 1983;130:341-349.

135. Levi-Schaffer F, Austen KF, Caulfield JP, Hein A, Gravallese PM, Stevens RL. Coculture of human lung-derived mast cells with mouse 3T3 fibroblasts: morphology and IgE-mediated release of histamine, prostaglandin D2, and leukotrienes. $J$ Immunol 1987;139:494-500.

136. Levi-Schaffer F, Kelav-Appelbaum R, Rubinchik E. Human foreskin mast cell viability and functional activity is maintained ex vivo by coculture with fibroblasts. Cell Immunol 1995;162:211-216.

137. Sellge G, Lorentz A, Gebhardt T, et al. Human intestinal fibroblasts prevent apoptosis in human intestinal mast cells by a mechanism independent of stem cell factor, IL-3, IL-4, and nerve growth factor. J Immunol 2004;172:260-267.

138. Moiseeva EP, Roach KM, Leyland ML, Bradding P. CADM1 Is a Key Receptor Mediating Human Mast Cell Adhesion to Human Lung Fibroblasts and Airway Smooth Muscle Cells. PLoS One 2013;8:e61579.

139. Montier Y, Lorentz A, Kramer S, et al. Central role of IL-6 and MMP-1 for cross talk between human intestinal mast cells and human intestinal fibroblasts. Immunobiology 2012;217:912-919.

140. Yamamoto T, Hartmann K, Eckes B, Krieg T. Mast cells enhance contraction of three-dimensional collagen lattices by fibroblasts by cell-cell interaction: role of stem cell factor/c-kit. Immunology 2000;99:435-439.

141. Bradding $\mathrm{P}$, Roberts $\mathrm{JA}$, Britten $\mathrm{KM}$, et al. Interleukin-4, -5 , and -6 and tumor necrosis factor-alpha in normal and asthmatic airways: evidence for the human mast cell as a source of these cytokines. Am J Respir Cell Mol Biol 1994;10:471-480.

142. Jones CA, Williams KA, Finlay-Jones JJ, Hart PH. Interleukin 4 production by human amnion epithelial cells and regulation of its activity by glycosaminoglycan binding. Biol Reprod 1995;52:839-847.

143. Joulia R, Gaudenzio N, Rodrigues M, et al. Mast cells form antibody-dependent degranulatory synapse for dedicated secretion and defence. Nat Commun 2015;6:6174.

144. Trautmann A, Toksoy A, Engelhardt E, Brocker EB, Gillitzer R. Mast cell involvement in normal human skin wound healing: expression of monocyte chemoattractant protein-1 is correlated with recruitment of mast cells which synthesize interleukin-4 in vivo. J Pathol 2000;190:100-106. 
145. Fitzgerald SM, Lee SA, Hall HK, Chi DS, Krishnaswamy G. Human lung fibroblasts express interleukin-6 in response to signaling after mast cell contact. Am J Respir Cell Mol Biol 2004;30:585-593.

146. Hollins F, Kaur D, Yang W, et al. Human Airway Smooth Muscle Promotes Human Lung Mast Cell Survival, Proliferation, and Constitutive Activation: Cooperative Roles for CADM1, Stem Cell Factor, and IL-6. J Immunol 2008;181:2772-2780.

147. Plante S, Semlali A, Joubert P, et al. Mast cells regulate procollagen I (alpha 1) production by bronchial fibroblasts derived from subjects with asthma through IL4/IL-4 delta 2 ratio. J Allergy Clin Immunol 2006;117:1321-1327.

148. Marquis BJ, Haynes CL. The effects of co-culture of fibroblasts on mast cell exocytotic release characteristics as evaluated by carbon-fiber microelectrode amperometry. Biophys Chem 2008;137:63-69.

149. Margulis A, Nocka KH, Brennan AM, et al. Mast cell-dependent contraction of human airway smooth muscle cell-containing collagen gels: influence of cytokines, matrix metalloproteases, and serine proteases. J Immunol 2009;183:1739-1750.

150. Termei R, Laschinger $\mathrm{C}$, Lee W, McCulloch CA. Intercellular interactions between mast cells and fibroblasts promote pro-inflammatory signaling. Exp Cell Res 2013;319:1839-1851.

151. Tsuruda T, Kato J, Hatakeyama K, et al. Adrenomedullin in mast cells of abdominal aortic aneurysm. Cardiovasc Res 2006;70:158-164.

152. Adachi S, Ebi Y, Nishikawa S, et al. Necessity of extracellular domain of W (c-kit) receptors for attachment of murine cultured mast cells to fibroblasts. Blood 1992;79:650-656.

153. Trautmann A, Feuerstein B, Ernst N, Brocker EB, Klein CE. Heterotypic cell-cell adhesion of human mast cells to fibroblasts. Arch Dermatol Res 1997;289:194-203.

154. Sanmugalingam D, Wardlaw AJ, Bradding P. Adhesion of human lung mast cells to bronchial epithelium: evidence for a novel carbohydrate-mediated mechanism. J Leuk Biol 2000;68:38-46.

155. Yang W, Kaur D, Okayama Y, et al. Human lung mast cells adhere to human airway smooth muscle, in part, via tumor suppressor in lung cancer-1. J Immunol 2006; 176:1238-1243.

156. Gough KC, Maddison BC, Shikotra A, et al. Evidence for a novel Kit adhesion domain mediating human mast cell adhesion to structural airway cells. Respir Res 2015;16:86.

157. Ito A, Jippo T, Wakayama T, et al. SgIGSF: a new mast-cell adhesion molecule used for attachment to fibroblasts and transcriptionally regulated by MITF. Blood 2003;101:2601-2608. 
158. Moiseeva EP, Straatman KR, Leyland ML, Bradding P. CADM1 Controls Actin Cytoskeleton Assembly and Regulates Extracellular Matrix Adhesion in Human Mast Cells. PLoS One 2014;9:e85980.

159. Moiseeva EP, Leyland ML, Bradding P. CADM1 is expressed as multiple alternatively spliced functional and dysfunctional isoforms in human mast cells. Mol Immunol 2012;53:345-354.

160. CADM1 isoforms differentially regulate human mast cell survival and homotypic adhesion. Cell Mol Life Sci 2012;69:2751-2764.

161. Kuramochi M, Fukuhara H, Nobukuni T, et al. TSLC1 is a tumor-suppressor gene in human non-small-cell lung cancer. Nat Genet 2001;27:427-430.

162. Mao X, Seidlitz E, Ghosh K, Murakami Y, Ghosh HP. The cytoplasmic domain is critical to the tumor suppressor activity of TSLC1 in non-small cell lung cancer. Cancer Res 2003;63:7979-7985.

163. Zhiling Y, Fujita E, Tanabe Y, Yamagata T, Momoi T, Momoi MY. Mutations in the gene encoding CADM1 are associated with autism spectrum disorder. Biochem Biophys Res Commun 2008;377:926-929.

164. Fujita E, Dai H, Tanabe Y, et al. Autism spectrum disorder is related to endoplasmic reticulum stress induced by mutations in the synaptic cell adhesion molecule, CADM1. Cell Death Dis 2010;1:e47.

165. Hasstedt SJ, Bezemer ID, Callas PW, et al. Cell adhesion molecule 1: a novel risk factor for venous thrombosis. Blood 2009;114:3084-3091.

166. Paun A, Haston CK. Genomic and genome-wide association of susceptibility to radiation-induced fibrotic lung disease in mice. Radiother Oncol 2012.

167. Shingai $\mathrm{T}$, Ikeda $\mathrm{W}$, Kakunaga $\mathrm{S}$, et al. Implications of nectin-like molecule2/IGSF4/RA175/SgIGSF/TSLC1/SynCAM1 in cell-cell adhesion and transmembrane protein localization in epithelial cells. J Biol Chem 2003;278:35421-35427.

168. Fogel AI, Akins MR, Krupp AJ, Stagi M, Stein V, Biederer T. SynCAMs organize synapses through heterophilic adhesion. J Neurosci 2007;27:12516-12530.

169. Galibert L, Diemer GS, Liu Z, et al. Nectin-like protein 2 defines a subset of T-cell zone dendritic cells and is a ligand for class-I-restricted T-cell-associated molecule. $J$ Biol Chem 2005;280:21955-21964.

170. Masuda M, Maruyama T, Ohta T, et al. CADM1 interacts with Tiam1 and promotes invasive phenotype of human T-cell leukemia virus type I-transformed cells and adult T-cell leukemia cells. J Biol Chem 2010;285:15511-15522.

171. Sakurai-Yageta M, Masuda M, Tsuboi Y, Ito A, Murakami Y. Tumor suppressor CADM1 is involved in epithelial cell structure. Biochem Biophys Res Commun 2009;390:977-982. 
172. Masuda M, Kikuchi S, Maruyama T, et al. Tumor suppressor in lung cancer (TSLC)1 suppresses epithelial cell scattering and tubulogenesis. J Biol Chem 2005;280:4216442171.

173. Mizutani K, Kawano S, Minami A, Waseda M, Ikeda W, Takai Y. Interaction of nectin-like molecule 2 with integrin alpha6beta4 and inhibition of disassembly of integrin alpha6beta4 from hemidesmosomes. J Biol Chem 2011;286:36667-36676.

174. Tsujimura T, Morii E, Nozaki M, et al. Involvement of transcription factor encoded by the mi locus in the expression of c-kit receptor tyrosine kinase in cultured mast cells of mice. Blood 1996;88:1225-1233.

175. Galli SJ, Tsai M, Marichal T, Tchougounova E, Reber LL, Pejler G. Approaches for analyzing the roles of mast cells and their proteases in vivo. Adv Immunol 2015;126:45-127.

176. Rodewald HR, Feyerabend TB. Widespread immunological functions of mast cells: fact or fiction? Immunity 2012;37:13-24.

177. Goto T, Befus D, Low R, Bienenstock J. Mast cell heterogeneity and hyperplasia in bleomycin-induced pulmonary fibrosis of rats. Am Rev Respir Dis 1984;130:797-802.

178. Aldenborg F, Nilsson K, Jarlshammar B, Bjermer L, Enerback L. Mast cells and biogenic amines in radiation-induced pulmonary fibrosis. Am J Respir Cell Mol Biol 1993;8:112-117.

179. Keith I, Day R, Lemaire S, Lemaire I. Asbestos-induced fibrosis in rats: increase in lung mast cells and autacoid contents. Exp Lung Res 1987;13:311-327.

180. Mori H, Kawada K, Zhang $\mathrm{P}$, et al. Bleomycin-induced pulmonary fibrosis in genetically mast cell- deficient WBB6F1-W/Wv mice and mechanism of the suppressive effect of tranilast, an antiallergic drug inhibiting mediator release from mast cells, on fibrosis. International Archives of Allergy \& Applied Immunology 1991;95:195-201.

181. Okazaki T, Hirota S, Xu ZD, et al. Increase of mast cells in the liver and lung may be associated with but not a cause of fibrosis: demonstration using mast cell-deficient Ws/Ws rats. Lab Invest 1998;78:1431-1438.

182. Masuda T, Tanaka H, Komai M, et al. Mast cells play a partial role in allergeninduced subepithelial fibrosis in a murine model of allergic asthma. Clin Exp Allergy 2003;33:705-713.

183. Yu M, Tsai M, Tam SY, Jones C, Zehnder J, Galli SJ. Mast cells can promote the development of multiple features of chronic asthma in mice. $J$ Clin Invest 2006;116:1633-1641.

184. Reber LL, Daubeuf F, Pejler G, Abrink M, Frossard N. Mast cells contribute to bleomycin-induced lung inflammation and injury in mice through a chymase/mast cell protease 4-dependent mechanism. J Immunol 2014;192:1847-1854. 
185. Veerappan A, O'Connor NJ, Brazin J, et al. Mast cells: a pivotal role in pulmonary fibrosis. DNA Cell Biol 2013;32:206-218.

186. O'Brien-Ladner AR, Wesselius LJ, Stechschulte DJ. Bleomycin injury of the lung in a mast-cell-deficient model. Agents Actions 1993;39:20-24.

187. Li Y, Zhou L, Liu F, et al. Mast cell infiltration is involved in renal interstitial fibrosis in a rat model of protein-overload nephropathy. Kidney Blood Press Res 2010;33:240248.

188. Veerappan A, Reid AC, O'Connor $\mathrm{N}$, et al. Mast cells are required for the development of renal fibrosis in the rodent unilateral ureteral obstruction model. Am J Physiol Renal Physiol 2012;302:F192-F204.

189. Miyazawa S, Hotta O, Doi N, Natori Y, Nishikawa K, Natori Y. Role of mast cells in the development of renal fibrosis: use of mast cell-deficient rats. Kidney Int 2004;65:2228-2237.

190. Kim DH, Moon SO, Jung YJ, et al. Mast cells decrease renal fibrosis in unilateral ureteral obstruction. Kidney Int 2009;75:1031-1038.

191. Summers SA, Gan PY, Dewage L, et al. Mast cell activation and degranulation promotes renal fibrosis in experimental unilateral ureteric obstruction. Kidney Int 2012;82:676-685.

192. Claman HN, Jaffee BD, Huff JC, Clark RA. Chronic graft-versus-host disease as a model for scleroderma. II. Mast cell depletion with deposition of immunoglobulins in the skin and fibrosis. Cell Immunol 1985;94:73-84.

193. Everett ET, Pablos JL, Harley RA, LeRoy EC, Norris JS. The role of mast cells in the development of skin fibrosis in tight-skin mutant mice. Comp Biochem Physiol A Physiol 1995;110:159-165.

194. Thevenot PT, Baker DW, Weng H, Sun MW, Tang L. The pivotal role of fibrocytes and mast cells in mediating fibrotic reactions to biomaterials. Biomaterials 2011;32:8394-8403.

195. Willenborg S, Eckes B, Brinckmann J, et al. Genetic ablation of mast cells redefines the role of mast cells in skin wound healing and bleomycin-induced fibrosis. J Invest Dermatol 2014;134:2005-2015.

196. Fairweather D, Frisancho-Kiss S, Yusung SA, et al. Interferon-gamma protects against chronic viral myocarditis by reducing mast cell degranulation, fibrosis, and the profibrotic cytokines transforming growth factor-beta 1, interleukin-1 beta, and interleukin-4 in the heart. Am J Pathol 2004;165:1883-1894.

197. Palaniyandi SS, Watanabe K, Ma M, Tachikawa H, Kodama M, Aizawa Y. Involvement of mast cells in the development of fibrosis in rats with postmyocarditis dilated cardiomyopathy. Biol Pharm Bull 2005;28:2128-2132. 
198. Zweifel M, Matozan K, Dahinden C, Schaffner T, Mohacsi P. Eotaxin/CCL11 levels correlate with myocardial fibrosis and mast cell density in native and transplanted rat hearts. Transplant Proc 2010;42:2763-2766.

199. Liao $\mathrm{CH}$, Akazawa H, Tamagawa M, et al. Cardiac mast cells cause atrial fibrillation through PDGF-A-mediated fibrosis in pressure-overloaded mouse hearts. J Clin Invest 2010;120:242-253.

200. Zhang W, Chancey AL, Tzeng HP, et al. The development of myocardial fibrosis in transgenic mice with targeted overexpression of tumor necrosis factor requires mast cell-fibroblast interactions. Circulation 2011;124:2106-2116.

201. Ruan YB, Wu ZB, Yang ML. [Role of mast cells in the development of liver fibrosis during experimental hepatocarcinogenesis in rats]. J Tongji Med Univ 1992;12:129133.

202. Xu X, Ruan YB, Wu ZB. Study on the role of mast cells in the development of liver fibrosis during diethylnitrosamine (DEN) -induced hepatocarcinogenesis in rats. $J$ Tongji Med Univ 1994;14:193-199.

203. Ramos SG, Montenegro AP, Goissis G, Rossi MA. Captopril reduces collagen and mast cell and eosinophil accumulation in pig serum-induced rat liver fibrosis. Pathol Int 1994;44:655-661.

204. Zhuravskii S, Yukina G, Kulikova O, et al. Mast cell accumulation precedes tissue fibrosis induced by intravenously administered amorphous silica nanoparticles. Toxicol Mech Methods 2016;26:260-269.

205. Sugihara A, Tsujimura T, Fujita Y, Nakata Y, Terada N. Evaluation of role of mast cells in the development of liver fibrosis using mast cell-deficient rats and mice. $J$ Hepatol 1999;30:859-867.

206. Hargrove L, Kennedy L, Demieville J, et al. Bile duct ligation-induced biliary hyperplasia, hepatic injury, and fibrosis are reduced in mast cell-deficient KitW-sh mice. Hepatology 2017;65:1991-2004.

207. Sainte-Marie G, Peng FS. Mast cells and fibrosis in compartments of lymph nodes of normal, gnotobiotic, and athymic rats. Cell Tissue Res 1990;261:1-15.

208. Fukushima H, Ohsawa M, Ikura Y, et al. Mast cells in diffuse large B-cell lymphoma; their role in fibrosis. Histopathology 2006;49:498-505.

209. Hirai S, Ohyane C, Kim YI, et al. Involvement of mast cells in adipose tissue fibrosis. Am J Physiol Endocrinol Metab 2014;306:E247-E255.

210. Scandiuzzi L, Beghdadi W, Daugas E, et al. Mouse mast cell protease-4 deteriorates renal function by contributing to inflammation and fibrosis in immune complexmediated glomerulonephritis. J Immunol 2010;185:624-633.

211. Younan G, Suber F, Xing W, et al. The inflammatory response after an epidermal burn depends on the activities of mouse mast cell proteases 4 and 5. J Immunol 2010;185:7681-7690. 
212. Beghdadi W, Madjene LC, Claver J, et al. Mast cell chymase protects against renal fibrosis in murine unilateral ureteral obstruction. Kidney Int 2013;84:317-326.

213. Tchougounova E, Lundequist A, Fajardo I, Winberg JO, Abrink M, Pejler G. A key role for mast cell chymase in the activation of pro-matrix metalloprotease- 9 and promatrix metalloprotease-2. J Biol Chem 2005;280:9291-9296.

214. Tchougounova E, Pejler G, Abrink M. The chymase, mouse mast cell protease 4, constitutes the major chymotrypsin-like activity in peritoneum and ear tissue. A role for mouse mast cell protease 4 in thrombin regulation and fibronectin turnover. $J$ Exp Med 2003;198:423-431.

215. Wei CC, Hase N, Inoue Y, et al. Mast cell chymase limits the cardiac efficacy of Ang I-converting enzyme inhibitor therapy in rodents. J Clin Invest 2010;120:1229-1239.

216. Kanbe N, Kurosawa M, Nagata H, Saitoh H, Miyachi Y. Cord blood-derived human cultured mast cells produce transforming growth factor beta1. Clin Exp Allergy 1999;29:105-113.

217. Taipale J, Lohi J, Saarinen J, Kovanen PT, Keski-Oja J. Human mast cell chymase and leukocyte elastase release latent transforming growth factor-beta 1 from the extracellular matrix of cultured human epithelial and endothelial cells. $J$ Biol Chem 1995;270:4689-4696.

218. Fang KC, Raymond WW, Blount JL, Caughey GH. Dog mast cell alpha-chymase activates progelatinase B by cleaving the Phe88-Gln89 and Phe91-Glu92 bonds of the catalytic domain. J Biol Chem 1997;272:25628-25635.

219. Van den Steen PE, Dubois B, Nelissen I, Rudd PM, Dwek RA, Opdenakker G. Biochemistry and molecular biology of gelatinase B or matrix metalloproteinase-9 (MMP-9). Crit Rev Biochem Mol Biol 2002;37:375-536.

220. Saarinen J, Kalkkinen N, Welgus HG, Kovanen PT. Activation of human interstitial procollagenase through direct cleavage of the Leu83-Thr84 bond by mast cell chymase. J Biol Chem 1994;269:18134-18140.

221. Gruber BL, Marchese MJ, Suzuki K, et al. Synovial procollagenase activation by human mast cell tryptase dependence upon matrix metalloproteinase 3 activation. $J$ Clin Invest 1989;84:1657-1662.

222. Magarinos NJ, Bryant KJ, Fosang AJ, Adachi R, Stevens RL, McNeil HP. Mast cellrestricted, tetramer-forming tryptases induce aggrecanolysis in articular cartilage by activating matrix metalloproteinase-3 and -13 zymogens. J Immunol 2013;191:14041412.

223. Klein T, Bischoff R. Physiology and pathophysiology of matrix metalloproteases. Amino Acids 2011;41:271-290.

224. Vartio T, Seppa H, Vaheri A. Susceptibility of soluble and matrix fibronectins to degradation by tissue proteinases, mast cell chymase and cathepsin G. J Biol Chem 1981;256:471-477. 
225. Tchougounova E, Forsberg E, Angelborg G, Kjellen L, Pejler G. Altered processing of fibronectin in mice lacking heparin. a role for heparin-dependent mast cell chymase in fibronectin degradation. J Biol Chem 2001;276:3772-3777.

226. Fajardo I, Pejler G. Human mast cell beta-tryptase is a gelatinase. J Immunol 2003;171:1493-1499.

227. Tomimori Y, Muto T, Saito K, et al. Involvement of mast cell chymase in bleomycininduced pulmonary fibrosis in mice. Eur J Pharmacol 2003;478:179-185.

228. Kosanovic D, Luitel H, Dahal BK, et al. Chymase: a multifunctional player in pulmonary hypertension associated with lung fibrosis. Eur Respir J 2015;46:10841094.

229. Sakaguchi M, Takai S, Jin D, et al. A specific chymase inhibitor, NK3201, suppresses bleomycin-induced pulmonary fibrosis in hamsters. Eur J Pharmacol 2004;493:173176.

230. Houde M, Jamain MD, Labonte J, et al. Pivotal role of mouse mast cell protease 4 in the conversion and pressor properties of Big-endothelin-1. J Pharmacol Exp Ther 2013;346:31-37.

231. Masubuchi S, Takai S, Jin D, et al. Chymase inhibitor ameliorates hepatic steatosis and fibrosis on established non-alcoholic steatohepatitis in hamsters fed a methionineand choline-deficient diet. Hepatol Res 2013;43:970-978.

232. Maeda $\mathrm{Y}$, Inoguchi $\mathrm{T}$, Takei R, et al. Chymase inhibition prevents myocardial fibrosis through the attenuation of NOX4-associated oxidative stress in diabetic hamsters. $J$ Diabetes Investig 2012;3:354-361.

233. Oyamada S, Bianchi C, Takai S, Chu LM, Sellke FW. Chymase inhibition reduces infarction and matrix metalloproteinase-9 activation and attenuates inflammation and fibrosis after acute myocardial ischemia/reperfusion. $J$ Pharmacol Exp Ther 2011;339:143-151.

234. Takato H, Yasui M, Ichikawa Y, et al. The specific chymase inhibitor TY-51469 suppresses the accumulation of neutrophils in the lung and reduces silica-induced pulmonary fibrosis in mice. Exp Lung Res 2011;37:101-108.

235. Komeda K, Takai S, Jin D, et al. Chymase inhibition attenuates tetrachloride-induced liver fibrosis in hamsters. Hepatol Res 2010;40:832-840.

236. Fan YY, Nishiyama A, Fujisawa Y, et al. Contribution of chymase-dependent angiotensin II formation to the progression of tubulointerstitial fibrosis in obstructed kidneys in hamsters. J Pharmacol Sci 2009;111:82-90.

237. Kanemitsu H, Takai S, Tsuneyoshi H, et al. Chymase inhibition prevents cardiac fibrosis and dysfunction after myocardial infarction in rats. Hypertens Res 2006;29:57-64.

238. Takai S, Jin D, Sakaguchi M, et al. A novel chymase inhibitor, 4-[1-([bis-(4-methylphenyl)-methyl]-carbamoyl)3-(2-ethoxy-benzyl)-4-oxo-azetidin e-2-yloxy]-benzoic 
acid (BCEAB), suppressed cardiac fibrosis in cardiomyopathic hamsters. $J$ Pharmacol Exp Ther 2003;305:17-23.

239. Matsumoto T, Wada A, Tsutamoto T, Ohnishi M, Isono T, Kinoshita M. Chymase inhibition prevents cardiac fibrosis and improves diastolic dysfunction in the progression of heart failure. Circulation 2003;107:2555-2558.

240. Li J, Jubair S, Levick SP, Janicki JS. The autocrine role of tryptase in pressure overload-induced mast cell activation, chymase release and cardiac fibrosis. IJC Metab Endocr 2016;10:16-23.

241. Lu J, Chen B, Li S, Sun Q. Tryptase inhibitor APC 366 prevents hepatic fibrosis by inhibiting collagen synthesis induced by tryptase/protease-activated receptor 2 interactions in hepatic stellate cells. Int Immunopharmacol 2014;20:352-357.

242. Xu X, Weksler-Zangen S, Pikarsky A, et al. Mast cells involvement in the inflammation and fibrosis development of the TNBS-induced rat model of colitis. Scand J Gastroenterol 2002;37:330-337.

243. Levick SP, McLarty JL, Murray DB, Freeman RM, Carver WE, Brower GL. Cardiac mast cells mediate left ventricular fibrosis in the hypertensive rat heart. Hypertension 2009;53:1041-1047.

244. Baba A, Tachi M, Ejima Y, et al. Less contribution of mast cells to the progression of renal fibrosis in Rat kidneys with chronic renal failure. Nephrology (Carlton) 2017;22:159-167.

245. Jones H, Hargrove L, Kennedy L, et al. Inhibition of mast cell-secreted histamine decreases biliary proliferation and fibrosis in primary sclerosing cholangitis Mdr2(-/-) mice. Hepatology 2016;64:1202-1216.

246. Oka T, Kalesnikoff J, Starkl P, Tsai M, Galli SJ. Evidence questioning cromolyn's effectiveness and selectivity as a 'mast cell stabilizer' in mice. Lab Invest 2012;92:1472-1482.

247. Gallant-Behm CL, Hildebrand KA, Hart DA. The mast cell stabilizer ketotifen prevents development of excessive skin wound contraction and fibrosis in red Duroc pigs. Wound Repair Regen 2008;16:226-233.

248. Monument MJ, Hart DA, Befus AD, Salo PT, Zhang M, Hildebrand KA. The mast cell stabilizer ketotifen reduces joint capsule fibrosis in a rabbit model of posttraumatic joint contractures. Inflamm Res 2012;61:285-292.

249. Leung KB, Flint KC, Brostoff $\mathrm{J}$, et al. Effects of sodium cromoglycate and nedocromil sodium on histamine secretion from human lung mast cells. Thorax 1988;43:756-761.

250. Okayama Y, Benyon RC, Rees PH, Lowman MA, Hillier K, Church MK. Inhibition profiles of sodium cromoglycate and nedocromil sodium on mediator release from mast cells of human skin, lung, tonsil, adenoid and intestine. Clin Exp Allergy 1992;22:401-409. 
251. Church MK, Hiroi J. Inhibition of IgE-dependent histamine release from human dispersed lung mast cells by anti-allergic drugs and salbutamol. $\mathrm{Br} J$ Pharmacol 1987;90:421-429.

252. Chong LK, Suvarna K, Chess-Williams R, Peachell PT. Desensitization of beta2adrenoceptor-mediated responses by short-acting beta2-adrenoceptor agonists in human lung mast cells. Br J Pharmacol 2003;138:512-520.

253. Le Provost GS, Pullar CE. beta2-adrenoceptor activation modulates skin wound healing processes to reduce scarring. J Invest Dermatol 2015;135:279-288.

254. Karoor V, Baltensperger K, Paul H, Czech MP, Malbon CC. Phosphorylation of tyrosyl residues $350 / 354$ of the beta-adrenergic receptor is obligatory for counterregulatory effects of insulin. J Biol Chem 1995;270:25305-25308.

255. Cruse G, Yang W, Duffy SM, et al. Counterregulation of beta(2)-adrenoceptor function in human mast cells by stem cell factor. J Allergy Clin Immunol 2010;125:257-263.

256. Lewis RJ, Chachi L, Newby C, Amrani Y, Bradding P. Bidirectional Counterregulation of Human Lung Mast Cell and Airway Smooth Muscle beta2 Adrenoceptors. J Immunol 2016;196:55-63.

257. Duffy SM, Lawley WJ, Conley EC, Bradding P. Resting and activation-dependent ion channels in human mast cells. J Immunol 2001;167:4261-4270.

258. Shumilina E, Lam RS, Wolbing F, et al. Blunted IgE-mediated activation of mast cells in mice lacking the $\mathrm{Ca}(2+)$-activated $\mathrm{K}(+)$ channel $\mathrm{K}(\mathrm{Ca}) 3.1$. J Immunol 2008;180:8040-8047.

259. Duffy SM, Ashmole I, Smallwood DT, Leyland ML, Bradding P. Orai/CRACM1 and KCa3.1 ion channels interact in the human lung mast cell plasma membrane. Cell Commun Signal 2015;13:32.

260. Duffy SM, Berger P, Cruse G, Yang W, Bolton SJ, Bradding P. The $\mathrm{K}^{+}$channel $\mathrm{IK}_{\mathrm{Ca}} 1$ potentiates $\mathrm{Ca}^{2+}$ influx and degranulation in human lung mast cells. J Allergy Clin Immunol 2004;114:66-72.

261. Organ L, Bacci B, Koumoundouros E, et al. Inhibition of the KCa3.1 Channel Alleviates Established Pulmonary Fibrosis in a Large Animal Model. Am J Respir Cell Mol Biol 2017;56:539-550.

262. Roach KM, Feghali-Bostwick C, Wulff H, Amrani Y, Bradding P. Human lung myofibroblast TGFbeta1-dependent Smad2/3 signalling is $\mathrm{Ca}(2+)$-dependent and regulated by $\mathrm{KCa} 3.1 \mathrm{~K}(+)$ channels. Fibrogenesis Tissue Repair 2015;8:5.

263. Arthur GK, Duffy SM, Roach KM, et al. KCa3.1 K+ Channel Expression and Function in Human Bronchial Epithelial Cells. PLoS One 2015;10:e0145259.

264. Freise $\mathrm{C}$, Heldwein S, Erben U, et al. $\mathrm{K}(+)$-channel inhibition reduces portal perfusion pressure in fibrotic rats and fibrosis associated characteristics of hepatic stellate cells. Liver Int 2015;35:1244-1252. 
265. Paka L, Smith DE, Jung D, et al. Anti-steatotic and anti-fibrotic effects of the KCa3.1 channel inhibitor, Senicapoc, in non-alcoholic liver disease. World J Gastroenterol 2017;23:4181-4190.

266. Huang C, Shen S, Ma Q, et al. Blockade of KCa3.1 ameliorates renal fibrosis through the TGF-beta1/Smad pathway in diabetic mice. Diabetes 2013;62:2923-2934.

267. Huang C, Shen S, Ma Q, Gill A, Pollock CA, Chen XM. KCa3.1 mediates activation of fibroblasts in diabetic renal interstitial fibrosis. Nephrol Dial Transplant 2014;29:313-324.

268. Tharp DL, Wamhoff BR, Wulff H, Raman G, Cheong A, Bowles DK. Local Delivery of the KCa3.1 Blocker, TRAM-34, Prevents Acute Angioplasty-Induced Coronary Smooth Muscle Phenotypic Modulation and Limits Stenosis. Arterioscler Thromb Vasc Biol 2008;28:1084-1089.

269. Zhao LM, Zhang W, Wang LP, Li GR, Deng XL. Advanced glycation end products promote proliferation of cardiac fibroblasts by upregulation of $\mathrm{KCa} 3.1$ channels. Pflugers Arch 2012;464:613-621.

270. Zhao LM, Wang LP, Wang HF, Ma XZ, Zhou DX, Deng XL. The role of KCa3.1 channels in cardiac fibrosis induced by pressure overload in rats. Pflugers Arch 2015;467:2275-2285.

271. Ju CH, Wang XP, Gao CY, Zhang SX, Ma XH, Liu C. Blockade of KCa3.1 Attenuates Left Ventricular Remodeling after Experimental Myocardial Infarction. Cell Physiol Biochem 2015;36:1305-1315.

272. Wang LP, Fan SJ, Li SM, Wang XJ, Gao JL, Yang XH. Protective role of ACE2Ang-(1-7)-Mas in myocardial fibrosis by downregulating KCa3.1 channel via ERK1/2 pathway. Pflugers Arch 2016;468:2041-2051.

273. Oxidative stress promotes myocardial fibrosis by upregulating KCa3.1 channel expression in AGT-REN double transgenic hypertensive mice. Pflugers Arch 2017.

274. Cahill KN, Katz HR, Cui J, et al. KIT Inhibition by Imatinib in Patients with Severe Refractory Asthma. N Engl J Med 2017;376:1911-1920.

275. Humbert M, de BF, Garcia G, et al. Masitinib, a c-kit/PDGF receptor tyrosine kinase inhibitor, improves disease control in severe corticosteroid-dependent asthmatics. Allergy 2009;64:1194-1201.

276. Yoneshige A, Hagiyama M, Inoue T, et al. Increased ectodomain shedding of cell adhesion molecule 1 as a cause of type II alveolar epithelial cell apoptosis in patients with idiopathic interstitial pneumonia. Respir Res 2015;16:90.

277. Garbuzenko E, Nagler A, Pickholtz D, et al. Human mast cells stimulate fibroblast proliferation, collagen synthesis and lattice contraction: a direct role for mast cells in skin fibrosis. Clin Exp Allergy 2002;32:237-246.

278. Lin L, Yamagata K, Nakayamada S, et al. Histamine inhibits differentiation of skin fibroblasts into myofibroblasts. Biochem Biophys Res Commun 2015;463:434-439. 
279. Yamashita Y, Nakagomi K, Takeda T, Hasegawa S, Mitsui Y. Effect of heparin on pulmonary fibroblasts and vascular cells. Thorax 1992;47:634-639.

280. Gruber BL, Schwartz LB, Ramamurthy NS, Irani AM, Marchese MJ. Activation of latent rheumatoid synovial collagenase by human mast cell tryptase. J Immunol 1988;140:3936-3942.

281. Lohi J, Harvima I, Keski-Oja J. Pericellular substrates of human mast cell tryptase: 72,000 dalton gelatinase and fibronectin. J Cell Biochem 1992;50:337-349.

282. Fajardo I, Pejler G. Formation of active monomers from tetrameric human betatryptase. Biochem J 2003;369:603-610.

283. Abe M, Kurosawa M, Ishikawa O, Miyachi Y, Kido H. Mast cell tryptase stimulates both human dermal fibroblast proliferation and type I collagen production. Clin Exp Allergy 1998;28:1509-1517.

284. Akers IA, Parsons M, Hill MR, et al. Mast cell tryptase stimulates human lung fibroblast proliferation via protease-activated receptor-2. Am J Physiol Lung Cell Mol Physiol 2000;278:L193-L201.

285. Asano-Kato N, Fukagawa K, Okada N, Dogru M, Tsubota K, Fujishima H. Tryptase increases proliferative activity of human conjunctival fibroblasts through proteaseactivated receptor-2. Invest Ophthalmol Vis Sci 2005;46:4622-4626.

286. Sawamukai N, Yukawa S, Saito K, Nakayamada S, Kambayashi T, Tanaka Y. Mast cell-derived tryptase inhibits apoptosis of human rheumatoid synovial fibroblasts via rho-mediated signaling. Arthritis Rheum 2010;62:952-959.

287. Cairns JA, Walls AF. Mast cell tryptase is a mitogen for epithelial cells. Stimulation of IL-8 production and intercellular adhesion molecule-1 expression. J Immunol 1996;156:275-283.

288. Tatler AL, Porte J, Knox A, Jenkins G, Pang L. Tryptase activates TGFbeta in human airway smooth muscle cells via direct proteolysis. Biochem Biophys Res Commun 2008;370:239-242.

289. Blair RJ, Meng H, Marchese MJ, et al. Human mast cells stimulate vascular tube formation. Tryptase is a novel, potent angiogenic factor. J Clin Invest 1997;99:26912700 .

290. Compton SJ, Cairns JA, Holgate ST, Walls AF. Human mast cell tryptase stimulates the release of an IL-8-dependent neutrophil chemotactic activity from human umbilical vein endothelial cells (HUVEC). Clin Exp Immunol 2000;121:31-36.

291. Pang L, Nie M, Corbett L, Sutcliffe A, Knox AJ. Mast cell beta-tryptase selectively cleaves eotaxin and RANTES and abrogates their eosinophil chemotactic activities. $J$ Immunol 2006;176:3788-3795.

292. Lefrancais E, Duval A, Mirey E, et al. Central domain of IL-33 is cleaved by mast cell proteases for potent activation of group-2 innate lymphoid cells. Proc Natl Acad Sci U $S$ A 2014;111:15502-15507. 
293. Lazaar AL, Plotnick MI, Kucich U, et al. Mast cell chymase modifies cell-matrix interactions and inhibits mitogen-induced proliferation of human airway smooth muscle Cells. J Immunol 2002;169:1014-1020.

294. Zhao W, Oskeritzian CA, Pozez AL, Schwartz LB. Cytokine production by skinderived mast cells: endogenous proteases are responsible for degradation of cytokines. J Immunol 2005;175:2635-2642.

295. Kofford MW, Schwartz LB, Schechter NM, Yager DR, Diegelmann RF, Graham MF. Cleavage of type I procollagen by human mast cell chymase initiates collagen fibril formation and generates a unique carboxyl-terminal propeptide. $J$ Biol Chem 1997;272:7127-7131.

296. Reilly CF, Tewksbury DA, Schechter NM, Travis J. Rapid conversion of angiotensin I to angiotensin II by neutrophil and mast cell proteinases. $J$ Biol Chem 1982;257:8619-8622.

297. Mizutani H, Schechter N, Lazarus G, Black RA, Kupper TS. Rapid and specific conversion of precursor interleukin 1 beta (IL-1 beta) to an active IL-1 species by human mast cell chymase. J Exp Med 1991;174:821-825.

298. Omoto Y, Tokime K, Yamanaka K, et al. Human mast cell chymase cleaves pro-IL18 and generates a novel and biologically active IL-18 fragment. J Immunol 2006; $177: 8315-8319$.

299. Longley BJ, Tyrrell L, Ma Y, et al. Chymase cleavage of stem cell factor yields a bioactive, soluble product. Proc Natl Acad Sci U S A 1997;94:9017-9021.

300. Kohyama T, Wyatt TA, Liu X, et al. PGD(2) modulates fibroblast-mediated native collagen gel contraction. Am J Respir Cell Mol Biol 2002;27:375-381.

301. Kohyama T, Liu XD, Wen FQ, Kim HJ, Takizawa H, Rennard SI. Prostaglandin D2 inhibits fibroblast migration. Eur Respir J 2002;19:684-689.

302. Ayabe S, Kida T, Hori M, Ozaki H, Murata T. Prostaglandin D2 inhibits collagen secretion from lung fibroblasts by activating the DP receptor. J Pharmacol Sci 2013;121:312-317.

303. Kida T, Ayabe S, Omori K, et al. Prostaglandin D2 Attenuates Bleomycin-Induced Lung Inflammation and Pulmonary Fibrosis. PLoS One 2016;11:e0167729.

304. Chibana K, Ishii Y, Asakura T, Fukuda T. Up-regulation of cysteinyl leukotriene 1 receptor by IL-13 enables human lung fibroblasts to respond to leukotriene C4 and produce eotaxin. J Immunol 2003;170:4290-4295.

305. Perng DW, Wu YC, Chang KT, et al. Leukotriene C4 induces TGF-beta1 production in airway epithelium via p38 kinase pathway. Am J Respir Cell Mol Biol 2006;34:101-107.

306. Yoshisue H, Kirkham-Brown J, Healy E, Holgate ST, Sampson AP, Davies DE. Cysteinyl leukotrienes synergize with growth factors to induce proliferation of human bronchial fibroblasts. J Allergy Clin Immunol 2007;119:132-140. 
307. Hirata H, Arima M, Fukushima Y, Sugiyama K, Tokuhisa T, Fukuda T. Leukotriene C4 aggravates bleomycin-induced pulmonary fibrosis in mice. Respirology 2013;18:674-681.

308. Nakajima T, Inagaki $\mathrm{N}$, Tanaka $\mathrm{H}$, et al. Marked increase in $\mathrm{CC}$ chemokine gene expression in both human and mouse mast cell transcriptomes following Fcepsilon receptor I cross-linking: an interspecies comparison. Blood 2002;100:3861-3868.

309. Gilchrest H, Cheewatrakoolpong B, Billah M, Egan RW, Anthes JC, Greenfeder S. Human cord blood-derived mast cells synthesize and release I-309 in response to IgE. Life Sciences 2003;73:2571-2581.

310. Feuser K, Thon KP, Bischoff SC, Lorentz A. Human intestinal mast cells are a potent source of multiple chemokines. Cytokine 2012;58:178-185.

311. Kato A, Chustz RT, Ogasawara T, et al. Dexamethasone and FK506 inhibit expression of distinct subsets of chemokines in human mast cells. J Immunol 2009; 182:7233-7243.

312. Brown MG, McAlpine SM, Huang YY, et al. RNA sensors enable human mast cell anti-viral chemokine production and IFN-mediated protection in response to antibody-enhanced dengue virus infection. PLoS One 2012;7:e34055.

313. Baghestanian M, Hofbauer R, Kiener HP, et al. The c-kit ligand stem cell factor and anti-IgE promote expression of monocyte chemoattractant protein-1 in human lung mast cells. Blood 1997;90:4438-4449.

314. Lee SA, Fitzgerald SM, Huang SK, et al. Molecular regulation of interleukin-13 and monocyte chemoattractant protein-1 expression in human mast cells by interleukin1beta. Am J Respir Cell Mol Biol 2004;31:283-291.

315. Aung G, Niyonsaba F, Ushio H, et al. Catestatin, a neuroendocrine antimicrobial peptide, induces human mast cell migration, degranulation and production of cytokines and chemokines. Immunology 2011;132:527-539.

316. Enoksson M, Ejendal KF, McAlpine S, Nilsson G, Lunderius-Andersson C. Human cord blood-derived mast cells are activated by the Nod1 agonist M-TriDAP to release pro-inflammatory cytokines and chemokines. J Innate Immun 2011;3:142-149.

317. King CA, Anderson R, Marshall JS. Dengue virus selectively induces human mast cell chemokine production. J Virol 2002;76:8408-8419.

318. Kaur D, Saunders R, Berger P, et al. Airway smooth muscle and mast cell-derived CC chemokine ligand 19 mediate airway smooth muscle migration in asthma. Am J Respir Crit Care Med 2006;174:1179-1188.

319. Lin TJ, Maher LH, Gomi K, McCurdy JD, Garduno R, Marshall JS. Selective early production of CCL20, or macrophage inflammatory protein 3alpha, by human mast cells in response to Pseudomonas aeruginosa. Infect Immun 2003;71:365-373.

320. Moller A, Lippert U, Lessmann D, et al. Human mast cells produce IL-8. J Immunol 1993;151:3261-3266. 
321. Lin TJ, Issekutz TB, Marshall JS. Human mast cells transmigrate through human umbilical vein endothelial monolayers and selectively produce IL-8 in response to stromal cell-derived factor-1 alpha. J Immunol 2000;165:211-220.

322. Lorentz A, Schwengberg S, Sellge G, Manns MP, Bischoff SC. Human intestinal mast cells are capable of producing different cytokine profiles: role of IgE receptor cross-linking and IL-4. J Immunol 2000;164:43-48.

323. Cruse G, Kaur D, Yang W, Duffy SM, Brightling CE, Bradding P. Activation of human lung mast cells by monomeric immunoglobulin E. Eur Respir J 2005;25:858863.

324. Babina M, Guhl S, Starke A, Kirchhof L, Zuberbier T, Henz BM. Comparative cytokine profile of human skin mast cells from two compartments--strong resemblance with monocytes at baseline but induction of IL-5 by IL-4 priming. $J$ Leukoc Biol 2004;75:244-252.

325. Gibbs BF, Wierecky J, Welker P, Henz BM, Wolff HH, Grabbe J. Human skin mast cells rapidly release preformed and newly generated TNF-alpha and IL-8 following stimulation with anti-IgE and other secretagogues. Exp Dermatol 2001;10:312-320.

326. Iikura M, Suto H, Kajiwara N, et al. IL-33 can promote survival, adhesion and cytokine production in human mast cells. Lab Invest 2007;87:971-978.

327. Allakhverdi Z, Comeau MR, Jessup HK, et al. Thymic stromal lymphopoietin is released by human epithelial cells in response to microbes, trauma, or inflammation and potently activates mast cells. J Exp Med 2007;204:253-258.

328. Okayama Y, Kobayashi H, Ashman LK, et al. Human lung mast cells are enriched in the capacity to produce granulocyte-macrophage colony-stimulating factor in response to IgE-dependent stimulation. Eur J Immunol 1998;28:708-715.

329. Kulka M, Alexopoulou L, Flavell RA, Metcalfe DD. Activation of mast cells by double-stranded RNA: evidence for activation through Toll-like receptor 3. J Allergy Clin Immunol 2004;114:174-182.

330. McCurdy JD, Olynych TJ, Maher LH, Marshall JS. Cutting Edge: Distinct Toll-like receptor 2 activators selectively induce different classes of mediator production from human mast cells. J Immunol 2003;170:1625-1629.

331. Elishmereni M, Alenius HT, Bradding P, et al. Physical interactions between mast cells and eosinophils: a novel mechanism enhancing eosinophil survival in vitro. Allergy 2011;66:376-385.

332. Brenner SA, Zacheja S, Schaffer M, Feilhauer K, Bischoff SC, Lorentz A. Soluble CD14 is essential for lipopolysaccharide-dependent activation of human intestinal mast cells from macroscopically normal as well as Crohn's disease tissue. Immunology 2014;143:174-183.

333. Okumura S, Kashiwakura J, Tomita H, et al. Identification of specific gene expression profiles in human mast cells mediated by Toll-like receptor 4 and FceRI. Blood 2003;102:2547-2554. 
334. Ishizuka T, Okayama Y, Kobayashi H, Mori M. Interleukin-3 production by mast cells from human lung. Inflammation 1999;23:25-35.

335. Bradding P, Feather IH, Howarth $\mathrm{PH}$, et al. Interleukin 4 is localized to and released by human mast cells. J Exp Med 1992;176:1381-1386.

336. Bradding P, Feather IH, Wilson S, et al. Immunolocalization of cytokines in the nasal mucosa of normal and perennial rhinitic subjects. The mast cell as a source of IL- 4, IL-5, and IL-6 in human allergic mucosal inflammation. J Immunol 1993;151:38533865 .

337. Okayama Y, Petit-Frere C, Kassel O, et al. IgE-dependent expression of mRNA for IL-4 and IL-5 in human lung mast cells. J Immunol 1995;155:1796-1808.

338. Wilson SJ, Shute JK, Holgate ST, Howarth PH, Bradding P. Localization of interleukin (IL) -4 but not IL-5 to human mast cell secretory granules by immunoelectron microscopy. Clin Exp Allergy 2000;30:493-500.

339. Brightling CE, Symon FA, Holgate ST, Wardlaw AJ, Pavord ID, Bradding P. IL-4 and IL-13 are co-localised to mast cells within airway smooth muscle in asthma. Clin Exp Allergy 2003;33:1711-1716.

340. Gibbs BF, Arm JP, Gibson K, Lee TH, Pearce FL. Human lung mast cells release small amounts of interleukin-4 and tumour necrosis factor-alpha in response to stimulation by anti- IgE and stem cell factor. Eur J Pharmacol 1997;327:73-78.

341. Hoffmann HJ, Dahl C, Schiotz PO, Berglund L, Dahl R. Lectins interact differentially with purified human eosinophils, cultured cord blood-derived mast cells and the myeloid leukaemic cell line AML14.3D10: induction of interleukin-4 secretion is conserved among granulocytes, but is not proportional to agglutination or lectinglycoprotein interaction. Clin Exp Allergy 2003;33:930-935.

342. Horsmanheimo L, Harvima IT, Jarvikallio A, Harvima RJ, Naukkarinen A, Horsmanheimo M. Mast cells are one major source of interleukin-4 in atopic dermatitis. Br J Dermatol 1994;131:348-353.

343. Ying S, Durham SR, Jacobson MR, et al. T lymphocytes and mast cells express messenger RNA for interleukin-4 in the nasal mucosa in allergen-induced rhinitis. Immunology 1994;82:200-206.

344. Bradding P, Feather IH, Wilson S, Holgate ST, Howarth, PH. Cytokine immunoreactivity in seasonal rhinitis: regulation by a topical corticosteroid. Am J Respir Crit Care Med 1995;151:1900-1906.

345. Ying S, Durham SR, Corrigan CJ, Hamid Q, Kay AB. Phenotype of cells expressing mRNA for TH2-type (interleukin 4 and interleukin 5) and TH1-type (interleukin 2 and interferon gamma) cytokines in bronchoalveolar lavage and bronchial biopsies from atopic asthmatic and normal control subjects. Am J Respir Cell Mol Biol 1995;12:477-487. 
346. Djukanovic R, Feather I, Gratziou C, et al. Effect of natural allergen exposure during the grass pollen season on airways inflammatory cells and asthma symptoms. Thorax 1996;51:575-581.

347. Pawankar R, Okuda M, Yssel H, Okumura K, Ra C. Nasal mast cells in perennial allergic rhinitics exhibit increased expression of the Fc epsilonRI, CD40L, IL-4, and IL-13, and can induce IgE synthesis in B cells. J Clin Invest 1997;99:1492-1499.

348. Ying S, Humbert M, Barkans J, et al. Expression of IL-4 and IL-5 mRNA and protein product by $\mathrm{CD} 4+$ and $\mathrm{CD} 8+\mathrm{T}$ cells, eosinophils, and mast cells in bronchial biopsies obtained from atopic and nonatopic (intrinsic) asthmatics. J Immunol 1997;158:35393544.

349. Cameron L, Hamid Q, Wright E, et al. Local synthesis of epsilon germline gene transcripts, IL-4, and IL-13 in allergic nasal mucosa after ex vivo allergen exposure. $J$ Allergy Clin Immunol 2000;106:46-52.

350. Saarinen JV, Harvima RJ, Naukkarinen A, Horsmanheimo M, Harvima IT. Interleukin-4-positive mast cells are highly associated with the extent of immediate allergic wheal reaction in the skin. Allergy 2001;56:58-64.

351. Wang M, Saxon A, Diaz-Sanchez D. Early IL-4 production driving Th2 differentiation in a human in vivo allergic model is mast cell derived. Clin Immunol 1999;90:47-54.

352. Machado DC, Horton D, Harrop R, Peachell PT, Helm BA. Potential allergens stimulate the release of mediators of the allergic response from cells of mast cell lineage in the absence of sensitization with antigen-specific IgE. Eur J Immunol 1996;26:2972-2980.

353. Sayama K, Diehn M, Matsuda K, et al. Transcriptional response of human mast cells stimulated via the Fc(epsilon)RI and identification of mast cells as a source of IL-11. BMC Immunol 2002;3:5.

354. Ying S, Durham SR, Barkans J, et al. T cells are the principal source of interleukin-5 mRNA in allergen-induced rhinitis. Am J Respir Cell Mol Biol 1993;9:356-360.

355. Jaffe JS, Glaum MC, Raible DG, et al. Human lung mast cell IL-5 gene and protein expression: temporal analysis of upregulation following IgE-mediated activation. Am J Respir Cell Mol Biol 1995;13:665-675.

356. Varadaradjalou S, Feger F, Thieblemont N, et al. Toll-like receptor 2 (TLR2) and TLR4 differentially activate human mast cells. Eur J Immunol 2003;33:899-906.

357. Cruse G, Cockerill S, Bradding P. IgE alone promotes human lung mast cell survival through the autocrine production of IL-6. BMC Immunol 2008;9:2.

358. Boudreau RT, Garduno R, Lin TJ. Protein phosphatase 2A and protein kinase Calpha are physically associated and are involved in Pseudomonas aeruginosa-induced interleukin 6 production by mast cells. J Biol Chem 2002;277:5322-5329. 
359. Oskeritzian CA, Zhao W, Pozez AL, Cohen NM, Grimes M, Schwartz LB. Neutralizing endogenous IL-6 renders mast cells of the MCT type from lung, but not the MCTC type from skin and lung, susceptible to human recombinant IL-4-induced apoptosis. J Immunol 2004;172:593-600.

360. Cruse G, Fernandes VE, de SJ, et al. Human lung mast cells mediate pneumococcal cell death in response to activation by pneumolysin. J Immunol 2010;184:7108-7115.

361. Nouri-Aria KT, Pilette C, Jacobson MR, Watanabe H, Durham SR. IL-9 and c-Kit+ mast cells in allergic rhinitis during seasonal allergen exposure: effect of immunotherapy. J Allergy Clin Immunol 2005;116:73-79.

362. Ishizuka T, Okayama Y, Kobayashi H, Mori M. Interleukin-10 is localized to and released by human lung mast cells. Clin Exp Allergy 1999;29:1424-1432.

363. Royer B, Varadaradjalou S, Saas P, et al. Autocrine regulation of cord blood-derived human mast cell activation by IL-10. J Allergy Clin Immunol 2001;108:80-86.

364. Jaffe JS, Raible DG, Post TJ, et al. Human lung mast cell activation leads to IL-13 mRNA expression and protein release. Am J Respir Cell Mol Biol 1996;15:473-481.

365. Toru H, Pawankar R, Ra C, Yata J, Nakahata T. Human mast cells produce IL-13 by high-affinity IgE receptor cross-linking: enhanced IL-13 production by IL-4-primed human mast cells. J Allergy Clin Immunol 1998;102:491-502.

366. Rumsaeng V, Cruikshank WW, Foster B, et al. Human mast cells produce the CD4+ T lymphocyte chemoattractant factor, IL-16. J Immunol 1997;159:2904-2910.

367. Hueber AJ, Asquith DL, Miller AM, et al. Mast cells express IL-17A in rheumatoid arthritis synovium. J Immunol 2010;184:3336-3340.

368. Suurmond J, Dorjee AL, Boon MR, et al. Mast cells are the main interleukin 17positive cells in anticitrullinated protein antibody-positive and -negative rheumatoid arthritis and osteoarthritis synovium. Arthritis Res Ther 2011;13:R150.

369. Mashiko S, Bouguermouh S, Rubio M, Baba N, Bissonnette R, Sarfati M. Human mast cells are major IL-22 producers in patients with psoriasis and atopic dermatitis. $J$ Allergy Clin Immunol 2015;136:351-359.

370. Shefler I, Pasmanik-Chor M, Kidron D, Mekori YA, Hershko AY. T cell-derived microvesicles induce mast cell production of IL-24: relevance to inflammatory skin diseases. J Allergy Clin Immunol 2014;133:217-224.

371. Walsh LJ, Trinchieri G, Waldorf HA, Whitaker D, Murphy, GF. Human dermal mast cells contain and release tumor necrosis factor alpha, which induces endothelial leukocyte adhesion molecule 1. Proc Natl Acad Sci USA 1991;88:4220-4224.

372. Bradding P, Mediwake R, Feather IH, et al. TNF alpha is localized to nasal mucosal mast cells and is released in acute allergic rhinitis. Clin Exp Allergy 1995;25:406-415. 
373. Ohkawara Y, Yamauchi K, Tanno Y, et al. Human lung mast cells and pulmonary macrophages produce tumor necrosis factor-alpha in sensitized lung tissue after IgE receptor triggering. Am J Respir Cell Mol Biol 1992;7:385-392.

374. Nilsson G, Forsberg-Nilsson K, Xiang Z, Hallbook F, Nilsson K, Metcalfe DD. Human mast cells express functional TrkA and are a source of nerve growth factor. Eur J Immunol 1997;27:2295-2301.

375. Bresciani M, Laliberte F, Laliberte MF, Gramiccioni C, Bonini S. Nerve growth factor localization in the nasal mucosa of patients with persistent allergic rhinitis. Allergy 2009;64:112-117.

376. Nilsson G, Svensson V, Nilsson K. Constitutive and inducible cytokine mRNA expression in the human mast cell line HMC-1. Scand J Immunol 1995;42:76-81.

377. Toda S, Tokuda Y, Koike N, et al. Growth factor-expressing mast cells accumulate at the thyroid tissue-regenerative site of subacute thyroiditis. Thyroid 2000;10:381-386.

378. van SL, Paridaens D, van MM, et al. Orbit-infiltrating mast cells, monocytes, and macrophages produce PDGF isoforms that orchestrate orbital fibroblast activation in Graves' ophthalmopathy. J Clin Endocrinol Metab 2012;97:E400-E408.

379. Abdel-Majid RM, Marshall JS. Prostaglandin E2 induces degranulation-independent production of vascular endothelial growth factor by human mast cells. J Immunol 2004; 172:1227-1236.

380. Detoraki A, Staiano RI, Granata F, et al. Vascular endothelial growth factors synthesized by human lung mast cells exert angiogenic effects. J Allergy Clin Immunol 2009;123:1142-9, 1149.

381. Grutzkau A, Kruger-Krasagakes S, Baumeister H, et al. Synthesis, storage, and release of vascular endothelial growth factor/vascular permeability factor (VEGF/VPF) by human mast cells: implications for the biological significance of VEGF206. Mol Biol Cell 1998;9:875-884.

382. Theoharides TC, Zhang B, Kempuraj D, et al. IL-33 augments substance P-induced VEGF secretion from human mast cells and is increased in psoriatic skin. Proc Natl Acad Sci U S A 2010;107:4448-4453.

383. Ying S, O'Connor B, Ratoff $\mathbf{J}$, et al. Thymic stromal lymphopoietin expression is increased in asthmatic airways and correlates with expression of Th2-attracting chemokines and disease severity. J Immunol 2005;174:8183-8190.

384. Okayama Y, Okumura S, Sagara H, et al. FcepsilonRI-mediated thymic stromal lymphopoietin production by interleukin-4-primed human mast cells. Eur Respir J 2009;34:425-435.

385. Shikotra A, Choy DF, Ohri CM, et al. Increased expression of immunoreactive thymic stromal lymphopoietin in patients with severe asthma. J Allergy Clin Immunol 2011;129:104-111. 
386. Wang SW, Oh CK, Cho SH, et al. Amphiregulin expression in human mast cells and its effect on the primary human lung fibroblasts. J Allergy Clin Immunol 2005;115:287-294.

387. Okumura S, Sagara H, Fukuda T, Saito H, Okayama Y. FcepsilonRI-mediated amphiregulin production by human mast cells increases mucin gene expression in epithelial cells. J Allergy Clin Immunol 2005;115:272-279. 
Table 1: Autacoid human mast cell mediators, heparin and proteases, and their

\section{biological effects relevant to fibrosis}

\begin{tabular}{|c|c|c|}
\hline Mediator & $\begin{array}{l}\text { Stored or newly } \\
\text { synthesised }\end{array}$ & Biological effects modulating fibrosis \\
\hline Histamine & Stored & $\begin{array}{ll}\text { - } & \uparrow \text { fibroblast proliferation via histamine H2 receptor }{ }^{110,277} \\
- & \uparrow \text { fibroblast collagen synthesis }{ }^{277} \text { and IL- } 6 \text { production }{ }^{139} \\
- & \uparrow \text { dermal skin fibroblast to myofibroblast differentiation }{ }^{127} \\
\text { or } \downarrow \text { dermal skin fibroblast to myofibroblast differentiation } \\
278\end{array}$ \\
\hline Heparin & Stored & $\begin{array}{ll}- & \text { Anticoagulant } \\
- & \text { Provides proteoglycan-based storage matrix for mediators in } \\
\text { MC granules } \\
-\quad \text { Stabilises tryptase } \\
-\quad \text { Sequesters growth factors to prevent their degradation } \\
-\quad \uparrow \quad \text { fibroblast proliferation at low concentrations, } \downarrow \\
\text { proliferation at high concentrations }{ }^{279} \\
-\quad \text { Enhances proliferative effects of bFGF }{ }^{279}\end{array}$ \\
\hline Tryptase & Stored & $\begin{array}{ll}- & \text { Indirectly activates collagenase } 221,280 \\
- & \text { Activates pro-MMP3 and }-13^{221,222} \\
- & \text { Degrades ECM } 226,281,282 \\
- & \uparrow \text { fibroblast proliferation }{ }^{73,277,283-285} \\
- & \uparrow \text { fibroblast collagen synthesis }{ }^{73,130,277} \text { and IL-6 production } \\
& 139 \\
- & \uparrow \text { fibroblast chemotaxis }{ }^{131} \\
- & \uparrow \text { fibroblast to myofibroblast differentiation }{ }^{127} \\
- & \uparrow \text { fibroblast contractility }{ }^{127} \\
- & \downarrow \text { fibroblast apoptosis }{ }^{286} \\
- & \text { Activates epithelial cells }{ }^{287} \\
- & \text { Activates TGF } \beta 1^{288} \\
- & \text { Promotes angiogenesis }{ }^{289} \\
- & \text { Promotes neutrophil recruitment }{ }^{290} \\
- & \text { Cleaves and inactivates CCL5 and }-11^{291} \\
- & \uparrow \text { IL-33 activity through proteolytic cleavage }{ }^{292} \\
\end{array}$ \\
\hline Chymase & Stored & 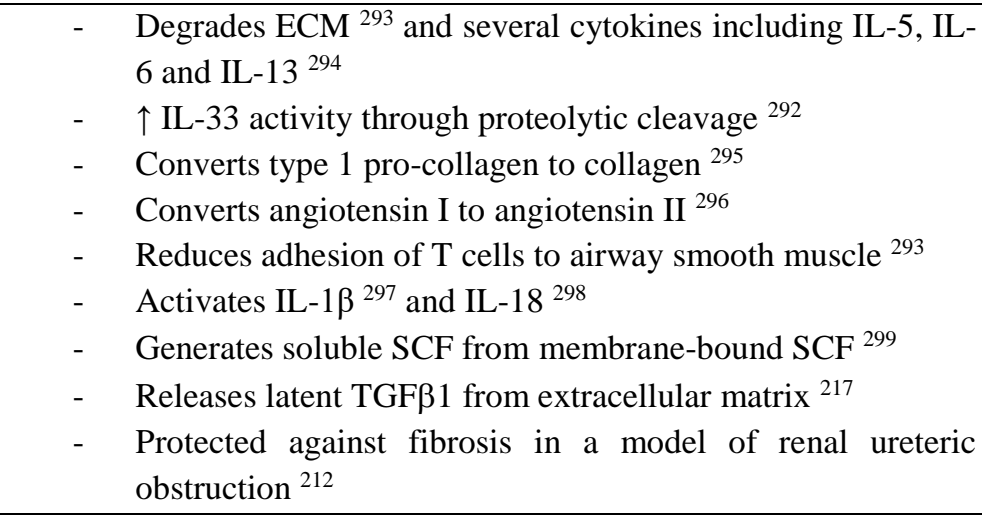 \\
\hline $\begin{array}{l}\text { Carboxypeptidase } \\
\text { A3 }\end{array}$ & Stored & - $\quad$ Increases fibroblast proliferation ${ }^{129}$ \\
\hline $\mathrm{PGD}_{2}$ & Newly synthesised & $\begin{array}{ll}- & \text { Stimulates fibroblast contraction }{ }^{300} \\
- & \downarrow \text { fibroblast migration }{ }^{301} \\
- & \downarrow \text { type I collagen secretion from lung fibroblasts secretion }\end{array}$ \\
\hline
\end{tabular}




\begin{tabular}{|c|c|c|}
\hline & & $\begin{array}{ll} & 302 \\
- & \uparrow \text { type I collagen secretion by dermal fibroblasts }{ }^{129} \\
- & \text { Enhances fibroblast proliferation }{ }^{129} \\
- & \text { Inhibits bleomycin-induced pulmonary fibrosis }{ }^{303}\end{array}$ \\
\hline $\begin{array}{l}\mathrm{LTC}_{4}(\text { and } \\
\text { extracellulary } \\
\text { derived } \mathrm{D}_{4} \text { and } \\
\left.\mathrm{E}_{4}\right)\end{array}$ & Newly synthesised & $\begin{array}{ll}\text { - } & \text { Stimulates CCL11 production from fibroblasts in the } \\
& \text { presence of IL-13 }{ }^{304} \\
- & \text { Induces TGF } \beta 1 \text { expression by epithelial cells } 305 \\
- & \text { Enhances EGF-dependent fibroblast proliferation } \\
- & \uparrow \text { fibroblast collagen secretion and proliferation }{ }^{129} \\
- & \text { Enhances bleomycin-induced pulmonary fibrosis } \\
307\end{array}$ \\
\hline
\end{tabular}


Table 2: Human mast cell-derived chemokines with potential roles in tissue fibrosis, either directly through activity on fibroblasts, or indirectly through effects on

\section{intermediaries in fibrotic processes}

\begin{tabular}{|c|c|c|}
\hline $\begin{array}{l}\text { Chemokine and known } \\
\text { inducing stimuli in mast } \\
\text { cells }\end{array}$ & Target cells & $\begin{array}{l}\text { Important biological effects of chemokine on target } \\
\text { cells }\end{array}$ \\
\hline \multicolumn{3}{|l|}{$-\mathrm{CC}-$} \\
\hline $\begin{array}{cl}\text { CCL1 } & \text { 308-311 } \\
- & \text { FceRI } \\
- & \text { IgE }\end{array}$ & $\mathrm{T}$ cells & $\mathrm{T}$ cell recruitment \\
\hline $\begin{aligned} \text { CCL2 } & \text { 308,310-315 } \\
\text { - } & \text { Constitutive } \\
\text { - } & \text { SCF } \\
\text { - } & \text { FceRI } \\
\text { - } & \text { Dengue virus } \\
\text { - } & \text { IL-1 } \beta \\
\text { - } & \text { Catestatin } \\
\text { - } & \text { Fibroblast contact }\end{aligned}$ & $\begin{array}{l}\text { Mast cells } \\
\text { Epithelial cells } \\
\text { T cells } \\
\text { Eosinophils } \\
\text { Monocytes } \\
\text { Basophils } \\
\text { Fibroblasts } \\
\text { (human IPF) } \\
\text { Fibroblasts } \\
\text { (human } \\
\text { scleroderma) } \\
\text { Fibrocytes }\end{array}$ & $\begin{array}{l}\text { Chemotaxis } \\
\text { Chemotaxis, proliferation } \\
\text { Induces Th2 phenotype } \\
\text { Chemotaxis } \\
\text { Chemotaxis } \\
\text { Activation, mediator release } \\
\uparrow \alpha \text { SMA, CTGF, TGF } \beta 1, \text { TGF } \beta R 2 \text { and pro-collagen I } \\
\text { expression } \\
\text { CCL2 autocrine loop upregulates } \alpha \text { SMA expression } \\
\text { Chemotaxis }\end{array}$ \\
\hline $\begin{aligned} \text { CCL3 } & \text { 308-312,315,316 } \\
- & \text { FceRI } \\
\text { - } & \text { Nod1 ligand } \\
- & \text { Dengue virus } \\
\text { - } & \text { catestatin } \\
- & \text { IgE }\end{aligned}$ & $\begin{array}{l}\text { Mast cells } \\
\text { T cells } \\
\text { Macrophages } \\
\text { Neutrophils } \\
\text { Eosinophils } \\
\text { Monocytes } \\
\text { Basophils }\end{array}$ & $\begin{array}{l}\text { Activation, mediator release } \\
\text { Chemotaxis (selective for Th1), induces Th1 phenotype } \\
\text { Differentiation } \\
\text { Chemotaxis (in vivo), cytotoxicity } \\
\text { Chemotaxis } \\
\text { Chemotaxis } \\
\text { Activation, mediator release }\end{array}$ \\
\hline $\begin{array}{ll}\text { CCL4 } & \text { 308,310-312,315,316 } \\
- & \text { FceRI } \\
\text { - } & \text { Nod1 ligand } \\
\text { - } & \text { Dengue virus } \\
- & \text { catestatin }\end{array}$ & $\begin{array}{l}\text { T cells } \\
\text { Eosinophils } \\
\text { Neutrophils }\end{array}$ & $\begin{array}{l}\text { Chemotaxis (selective for Th1), induces Th1 phenotype } \\
\text { Chemotaxis } \\
\text { Chemotaxis (in vivo) }\end{array}$ \\
\hline $\begin{array}{l}\text { CCL5 } \\
\begin{aligned} & 308,310,317 \\
- & \text { FceRI } \\
- & \text { Dengue virus }\end{aligned}\end{array}$ & $\begin{array}{l}\text { Mast cells } \\
\text { T cells } \\
\text { Eosinophils } \\
\text { Monocytes } \\
\text { Fibroblasts } \\
\text { (gingival) }\end{array}$ & $\begin{array}{l}\text { Chemotaxis } \\
\text { Chemotaxis (selective for Th1), induces Th1 phenotype } \\
\text { Chemotaxis } \\
\text { Chemotaxis } \\
\text { Chemotaxis, proliferation }\end{array}$ \\
\hline $\begin{array}{r}\text { CCL7 } \\
-\quad \text { FceRI }\end{array}$ & $\begin{array}{l}\text { Eosinophils } \\
\text { Monocytes } \\
\text { Basophils }\end{array}$ & $\begin{array}{l}\text { Chemotaxis } \\
\text { Chemotaxis } \\
\text { Activation, mediator release }\end{array}$ \\
\hline $\begin{array}{cc}\text { CCL8 } & \text { 310,312 } \\
- & \text { Constitutive } \\
- & \text { Dengue virus }\end{array}$ & $\begin{array}{l}\text { T cells } \\
\text { Basophils } \\
\text { B cells } \\
\text { Eosinophils }\end{array}$ & $\begin{array}{l}\text { Chemotaxis } \\
\text { Chemotaxis, histamine release } \\
\text { Chemotaxis } \\
\text { Chemotaxis }\end{array}$ \\
\hline 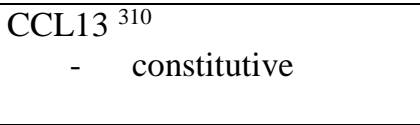 & $\begin{array}{l}\text { Eosinophils } \\
\text { Basophils } \\
\text { Monocytes }\end{array}$ & $\begin{array}{l}\text { Chemotaxis } \\
\text { Histamine release, chemotaxis } \\
\text { Chemotaxis }\end{array}$ \\
\hline
\end{tabular}




\begin{tabular}{|c|c|c|}
\hline & $\begin{array}{l}\text { Immature } \\
\text { dendritic cells } \\
\mathrm{T} \text { cells } \\
\text { Endothelial cells } \\
\text { Fibroblasts } \\
\end{array}$ & $\begin{array}{l}\text { Chemotaxis } \\
\text { Chemotaxis } \\
\text { Chemotaxis } \\
\text { Inhibits apoptosis } \\
\end{array}$ \\
\hline $\begin{array}{c}\text { CCL17 } \\
\text { - } \quad \text { constitutive }\end{array}$ & T cells & Chemotaxis (selective for Th2) \\
\hline $\begin{array}{c}\text { CCL18 } \\
\begin{array}{c}310,311 \\
- \\
\text { FceRI }\end{array}\end{array}$ & $\begin{array}{l}\text { Epithelial cells } \\
\text { T cells } \\
\text { B cells } \\
\text { Immature } \\
\text { dendritic cells } \\
\text { Basophils } \\
\text { Macrophages }\end{array}$ & $\begin{array}{l}\text { Epithelial mesenchymal transition } \\
\text { Chemotaxis } \\
\text { Modulates activation and chemokine-induced responses } \\
\text { Chemotaxis } \\
\text { Chemotaxis, histamine release } \\
\text { Chemotaxis, activation }\end{array}$ \\
\hline $\begin{array}{c}\text { CCL19 } \\
\text { 310,318 } \\
-\quad \text { constitutive }\end{array}$ & $\begin{array}{l}\text { Airway smooth } \\
\text { muscle cells }\end{array}$ & Chemotaxis \\
\hline $\begin{array}{ll}\text { CCL20 } & \text { 310,319 } \\
- & \text { FceRI } \\
- & \text { Pseudomonas }\end{array}$ & $\begin{array}{l}\text { Dendritic cells } \\
\mathrm{T} \text { cells } \\
\text { Fibroblasts } \\
\text { (gingival) }\end{array}$ & $\begin{array}{l}\text { Chemotaxis } \\
\text { Chemotaxis } \\
\text { Chemotaxis, proliferation }\end{array}$ \\
\hline 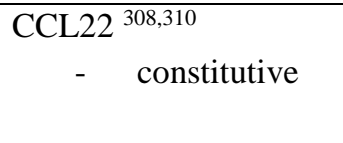 & $\begin{array}{l}\text { T cells } \\
\text { Fibroblasts } \\
\text { (gingival) }\end{array}$ & $\begin{array}{l}\text { Chemotaxis (selective for Th2) } \\
\text { Chemotaxis, } \uparrow I L-6 \text { secretion }\end{array}$ \\
\hline $\begin{array}{c}\text { CCL23 } \\
-\quad \text { FceRI }\end{array}$ & $\begin{array}{l}\text { Monocytes } \\
\text { T cells } \\
\text { Neutrophils } \\
\text { Myeloid } \\
\text { progenitor cells } \\
\text { Dendritic cells }\end{array}$ & $\begin{array}{l}\text { Chemotaxis, adhesion, mediator release } \\
\text { Chemotaxis } \\
\text { Chemotaxis } \\
\text { Suppressed development } \\
\text { Chemotaxis }\end{array}$ \\
\hline 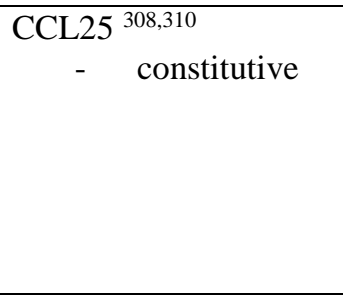 & $\begin{array}{l}\text { Periosteal } \\
\text { progenitor cells } \\
\text { Lymphocytes } \\
\text { Mesenchymal } \\
\text { stem cells } \\
\text { Fibroblasts } \\
\text { (gingival) } \\
\end{array}$ & $\begin{array}{l}\text { Chemotaxis } \\
\text { Adhesion } \\
\text { Chemotaxis } \\
\text { Chemotaxis }\end{array}$ \\
\hline $\begin{array}{c}\text { CCL28 } \\
\begin{array}{c}310 \\
-\end{array}\end{array}$ & $\begin{array}{l}\text { Lymphocytes } \\
\text { T cells } \\
\text { Haematopoietic } \\
\text { progenitor cells } \\
\text { Fibroblasts } \\
\text { (gingival) }\end{array}$ & $\begin{array}{l}\text { Adhesion } \\
\text { Migration } \\
\text { Growth and survival } \\
\text { Chemotaxis, proliferation, } \uparrow I L-6 \text { secretion }\end{array}$ \\
\hline \multicolumn{3}{|l|}{$-\mathrm{CXC}-$} \\
\hline $\begin{array}{l}\text { CXCL2 } \\
\begin{aligned} & 310 \\
- & \text { FceRI }\end{aligned}\end{array}$ & $\begin{array}{l}\text { Neutrophils } \\
\text { Airway smooth } \\
\text { muscle cells }\end{array}$ & $\begin{array}{l}\text { Chemotaxis, adhesion } \\
\text { Migration }\end{array}$ \\
\hline 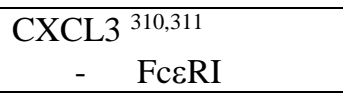 & $\begin{array}{l}\text { Airway smooth } \\
\text { muscle cells }\end{array}$ & Migration \\
\hline $\begin{array}{c}\text { CXCL4 } \\
-\quad \text { constitutive }\end{array}$ & $\begin{array}{l}\text { T cells } \\
\text { Endothelial cells } \\
\text { Monocytes } \\
\text { Neutrophils }\end{array}$ & $\begin{array}{l}\text { Chemotaxis } \\
\text { Angiogenesis } \\
\text { Impairs chemotaxis } \\
\text { Adhesion }\end{array}$ \\
\hline $\begin{array}{l}\text { CXCL5 } \\
\begin{array}{c}310 \\
-\quad \text { constitutive }\end{array}\end{array}$ & Neutrophils & Chemotaxis \\
\hline $\begin{array}{c}\text { CXCL7 } \\
\text { CX12 } \\
-\quad \text { constitutive } \\
\end{array}$ & Neutrophils & Chemotaxis, degranulation \\
\hline
\end{tabular}




\begin{tabular}{|c|c|c|}
\hline - $\quad$ Dengue virus & & \\
\hline $\begin{aligned} \text { CXCL8 } & \text { 310-312,316,320-327 } \\
- & \text { constitutive } \\
- & \text { IgE } \\
- & \text { FcERI } \\
- & \text { CXCL12 } \\
- & \text { substance P } \\
- & \text { TSLP + IL-1 } \\
- & \text { IL-33 } \\
- & \text { Nod1 ligand } \\
- & \text { Dengue virus }\end{aligned}$ & $\begin{array}{l}\text { Mast cells } \\
\text { Endothelial cells } \\
\text { Neutrophils } \\
\text { Eosinophils } \\
\text { Fibroblasts } \\
\text { (human airway) }\end{array}$ & $\begin{array}{l}\text { Reduces chemotaxis and mediator release } \\
\text { Chemotaxis, proliferation, survival, angiogenesis } \\
\text { Chemotaxis } \\
\text { Chemotaxis following priming with IL-3, IL-5 or GM-CSF } \\
\text { Chemotaxis }\end{array}$ \\
\hline $\begin{aligned} \text { CXCL10 } & \text { 310,312 } \\
- & \text { Constitutive } \\
- & \text { Dengue virus }\end{aligned}$ & $\begin{array}{l}\text { Mast cells } \\
\text { Fibroblasts } \\
\text { (human airway) }\end{array}$ & $\begin{array}{l}\text { Chemotaxis } \\
\text { Chemotaxis }\end{array}$ \\
\hline $\begin{array}{l}\text { CXCL14 } \\
\quad{ }^{310} \\
-\quad \text { constitutive }\end{array}$ & $\begin{array}{l}\text { Bacteria } \\
\text { Monocytes } \\
\text { Dendritic cells }\end{array}$ & $\begin{array}{l}\text { Anti-microbial action } \\
\text { Chemotaxis } \\
\text { Chemotaxis }\end{array}$ \\
\hline $\begin{aligned} \text { CXCL16 } & 310 \\
- & \text { constitutive }\end{aligned}$ & $\begin{array}{l}\text { T cells } \\
\text { Monocytes }\end{array}$ & $\begin{array}{l}\text { Chemotaxis } \\
\text { Chemotaxis }\end{array}$ \\
\hline $\begin{array}{l}\text { CXCL17 } \\
-\quad \text { constitutive }\end{array}$ & $\begin{array}{l}\text { Bacteria } \\
\text { Dendritic cells } \\
\text { Monocytes }\end{array}$ & $\begin{array}{l}\text { Anti-microbial action } \\
\text { Chemotaxis } \\
\text { Chemotaxis }\end{array}$ \\
\hline \multicolumn{3}{|l|}{$-\mathrm{C}-$} \\
\hline XCL1 ${ }^{310}$ & $\begin{array}{l}\text { T cells } \\
\text { Fibroblasts } \\
\text { (gingival) }\end{array}$ & $\begin{array}{l}\text { Chemotaxis, activation apoptosis } \\
\text { Chemotaxis, proliferation }\end{array}$ \\
\hline \multicolumn{3}{|l|}{-CX3C- } \\
\hline CX3CL1 ${ }^{310}$ & $\begin{array}{l}\text { Mast cells } \\
\text { Leukocytes } \\
\text { Fibroblasts } \\
\text { (synovial) } \\
\text { Fibroblasts } \\
\text { (gingival) }\end{array}$ & $\begin{array}{l}\text { Chemotaxis } \\
\text { Chemotaxis, adhesion } \\
\uparrow \text { MMP2 production } \\
\text { Chemotaxis }\end{array}$ \\
\hline
\end{tabular}


Table 3: Human mast cell-derived cytokines with potential roles in tissue fibrosis, either

directly through activity on fibroblasts, or indirectly through effects on intermediaries

\section{in fibrotic processes}

\begin{tabular}{|c|c|c|}
\hline $\begin{array}{l}\text { Cytokine and known inducing } \\
\text { stimuli in mast cells }\end{array}$ & Target cells & $\begin{array}{l}\text { Important biological effects of cytokine } \\
\text { on target cells }\end{array}$ \\
\hline \multirow{2}{*}{$\begin{aligned} \text { GM-CSF } & \text { 309,327-331 } \\
- & \text { constitutive } \\
- & \text { IgE } \\
- & \text { FceRI } \\
- & \text { Fc } \gamma R I \\
- & \text { TLR2 } \\
- & \text { TSLP + IL-1 } \beta \\
- & \text { eosinophil contact }\end{aligned}$} & Eosinophils & $\begin{array}{l}\text { Eosinophil growth, adhesion, } \\
\text { transendothelial migration, chemotaxis, } \\
\text { activation }\end{array}$ \\
\hline & Mast cells & $\begin{array}{l}\downarrow \text { tryptase expression, } \uparrow F c \varepsilon R I \text {-dependent } \\
\text { histamine release }\end{array}$ \\
\hline \multirow{7}{*}{$\begin{aligned} \text { IL-1 } & \beta \\
- & \text { constitutive } \\
- & \text { Fc } \gamma \text { RI } \\
- & \text { TLR2,-4, }-5,-9 \\
- & \text { IFN } \gamma\end{aligned}$} & Mast cells & $\begin{array}{l}\text { Induces histamine release from adenoidal } \\
\mathrm{MCs}, \uparrow \text { uterine MC adhesion }\end{array}$ \\
\hline & $\mathrm{T}$ cells & Activation \\
\hline & B cells & Augments proliferation and Ig synthesis \\
\hline & Hepatocytes & Acute phase protein release \\
\hline & Endothelial cells & Adhesion molecule expression \\
\hline & Airway smooth muscle & Uncouples $\beta_{2}$-adrenoceptor \\
\hline & Airway epithelium & $\begin{array}{l}\text { GM-CSF secretion, } \uparrow \text { ICAM-1 } \\
\text { expression, } \uparrow \text { neutrophil and eosinophil } \\
\text { adhesion }\end{array}$ \\
\hline \multirow[t]{3}{*}{$\begin{array}{l}\text { IL-3 } \\
-\quad \text { FceRI }\end{array}$} & Mast cells & $\begin{array}{l}\text { Growth, differentiation, and survival of } \\
\text { bone marrow progenitor cells }\end{array}$ \\
\hline & Eosinophils & $\begin{array}{l}\text { Eosinophil growth, adhesion, } \\
\text { transendothelial migration, chemotaxis, } \\
\text { activation }\end{array}$ \\
\hline & Basophils & Survival, activation \\
\hline \multirow{6}{*}{$\begin{aligned} \text { IL-4 } & \text { 60,117,141,144,335-353 } \\
- & \text { FceRI } \\
- & \text { lectins } \\
- & \text { proteases } \\
- & \text { fibroblast contact } \\
- & \text { constitutive mRNA } \\
& \text { expression in asthmatic } \\
& \text { airways }\end{aligned}$} & Mast cells & $\begin{array}{l}\uparrow \mathrm{Fc \varepsilon RI} \text { and releasability, } \uparrow \mathrm{ICAM}-1 \\
\text { expression, } \uparrow \text { sensitivity to adenosine, } \\
\text { apoptosis of } \mathrm{MC}_{\mathrm{T}} \text { but not } \mathrm{MC}_{\mathrm{TC}}\end{array}$ \\
\hline & B cells & $\begin{array}{l}\text { Proliferation, increases MHC class II, } \\
\text { CD40 and CD } 25 \text { expression, IgE class } \\
\text { switching and secretion, } \uparrow \text { IL- } 6 \text { release }\end{array}$ \\
\hline & T cells & $\begin{array}{l}\text { Proliferation, promotes a Th2 cell } \\
\text { phenotype }\end{array}$ \\
\hline & Monocytes/macrophages & $\begin{array}{l}\text { Reduces } \mathrm{H}_{2} \mathrm{O}_{2} \text { and } \mathrm{O}_{2} \text { production, } \\
\text { attenuates parasite killing and tumoricidal } \\
\text { activity, induces monocyte to macrophage } \\
\text { differentiation, } \downarrow \text { IL-1, IL- } 6 \text {, IL- } 8 \text {, TNF- } \alpha \\
\text { and } 15 \text {-lipoxygenase production, } \uparrow \text { MHC } \\
\text { class II and CD23 expression }\end{array}$ \\
\hline & Eosinophils & $\begin{array}{l}\text { Transendothelial migration, activation, } \\
\text { primes for CCL5-dependent migration }\end{array}$ \\
\hline & Fibroblasts & $\begin{array}{l}\text { Proliferation and chemotaxis, } \\
\text { transformation to myofibroblasts, } \uparrow \\
\text { integrin expression and extracellular } \\
\text { matrix deposition, } \uparrow \text { chemokine and } \\
\text { cytokine release }\end{array}$ \\
\hline
\end{tabular}




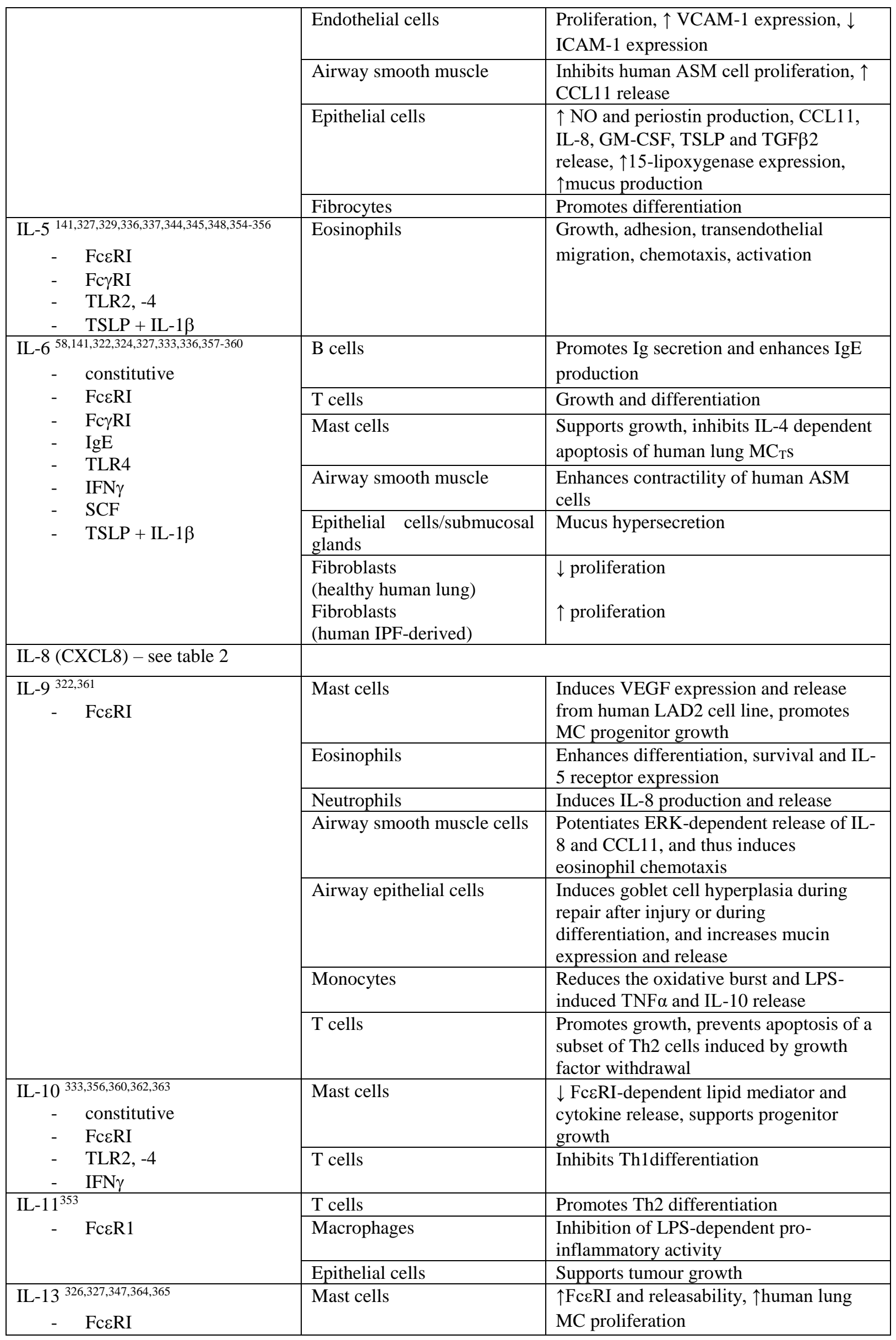




\begin{tabular}{|c|c|c|}
\hline \multirow{9}{*}{$\begin{array}{ll}- & \text { Fc } \gamma \text { RI } \\
- & \text { TSLP + IL-1 } \beta \\
- & \text { IL-33 }\end{array}$} & B cells & IgE class switching and secretion \\
\hline & $\mathrm{T}$ cells & Promotes Th2 responses \\
\hline & Monocytes/macrophages & Same as IL-4 (see above) \\
\hline & Eosinophils & Activation, survival \\
\hline & Endothelial cells & Increases VCAM-1 expression \\
\hline & Epithelial cells & $\begin{array}{l}\uparrow \mathrm{NO} \text { and periostin production, CCL11, } \\
\text { GM-CSF, TSLP and TGF } \beta 2 \text { release, } \\
\uparrow \text { mucus production }\end{array}$ \\
\hline & Airway smooth muscle & $\begin{array}{l}\text { Enhances sensitivity to contractile } \\
\text { agonists }\end{array}$ \\
\hline & Fibroblasts & $\begin{array}{l}\text { Proliferation, transformation to } \\
\text { myofibroblasts, } \uparrow \text { integrin expression and } \\
\text { extracellular matrix deposition, } \\
\uparrow \text { chemokine and cytokine release }\end{array}$ \\
\hline & Fibrocytes & Promotes differentiation \\
\hline IL-16 322,366 & $\mathrm{~T}$ cells & Th1 chemotaxis, inhibits Th2 activation \\
\hline IL-17A $A^{367-369}$ & Epithelial cells & Enhances mucus secretion \\
\hline \multirow{3}{*}{$\begin{array}{ll}- & \text { TNF } \alpha \\
- & \text { IgG complexes } \\
- & \text { C5a } \\
- & \text { TLR4 (LPS) }\end{array}$} & Airway smooth muscle & $\begin{array}{l}\text { Enhances sensitivity to contractile } \\
\text { agonists }\end{array}$ \\
\hline & Neutrophils & $\begin{array}{l}\text { Indirectly promotes recruitment through } \\
\text { chemokine upregulation }\end{array}$ \\
\hline & Fibroblasts & $\begin{array}{l}\text { Synergises with TNF } \alpha \text { to } \uparrow \text { IL- } 6 \text { and IL- } 6 \\
\text { production }\end{array}$ \\
\hline IL-18 322 & Lymphocytes & $\begin{array}{l}\uparrow \text { IFN } \gamma \text { production from Th1, CD8 and } \\
\text { NK cells }\end{array}$ \\
\hline \multirow{3}{*}{$\begin{array}{cl}\text { IL-22 } & 369 \\
- & \text { stimuli not known, mRNA } \\
& \text { expressed constitutively in } \\
& \text { psoriatic skin }\end{array}$} & Keratinocytes & $\begin{array}{l}\text { Epidermal hyperplasia, antimicrobial } \\
\text { peptide secretion, } \uparrow \text { VEGF secretion } \\
\text { promoting angiogenesis }\end{array}$ \\
\hline & Epithelial cells & $\begin{array}{l}\text { Proliferation, antimicrobial peptide } \\
\text { secretion, inhibits IL-25 release by airway } \\
\text { epithelial cells }\end{array}$ \\
\hline & Airway smooth muscle & $\begin{array}{l}\text { Enhances sensitivity to contractile } \\
\text { agonists, prevents apoptosis, } \uparrow \text { migration }\end{array}$ \\
\hline $\begin{array}{rr}\text { IL-24 } & 370 \\
- & \text { T cell-derived } \\
\text { microvesicles }\end{array}$ & Keratinocytes & $\begin{array}{l}\uparrow \text { secretion of pro-inflammatory } \\
\text { mediators }\end{array}$ \\
\hline \multirow{8}{*}{$\begin{aligned} \text { TNF } \alpha & \text { 141,316,333,371-373 } \\
- & \text { FceRI } \\
- & \text { Fc } \gamma R I \\
- & \text { TLR4, -5, -9 } \\
- & \text { IFN } \gamma \\
- & \text { Nod1 ligand }\end{aligned}$} & Monocytes/macrophages & $\begin{array}{l}\text { Increases cytotoxicity, chemotaxis, and } \\
\text { prolonged survival }\end{array}$ \\
\hline & $\mathrm{T}$ cells & $\begin{array}{l}\text { Promotes class II antigen and IL-2 } \\
\text { receptor expression, and increases } \\
\text { proliferation }\end{array}$ \\
\hline & Neutrophils & Increases cytotoxicity and chemotaxis \\
\hline & Eosinophils & $\begin{array}{l}\text { Increases cytotoxicity and oxidant } \\
\text { production }\end{array}$ \\
\hline & Endothelial cells & $\begin{array}{l}\text { Increases E-selectin, ICAM-1 and } \\
\text { VCAM-1 expression, and enhances } \\
\text { extravasation of most leucocytes }\end{array}$ \\
\hline & Fibroblasts & $\begin{array}{l}\text { Growth and chemotaxis, } \downarrow \text { collagen } \\
\text { production, } \uparrow \text { collagenase, IL- } 6 \text { and IL- } 8 \\
\text { production }\end{array}$ \\
\hline & Epithelial cells & $\begin{array}{l}\uparrow \text { eosinophil adhesion, } \uparrow \text { mucus } \\
\text { production }\end{array}$ \\
\hline & Airway smooth muscle & $\uparrow$ sensitivity to contractile agonists, \\
\hline
\end{tabular}




\begin{tabular}{|c|c|c|}
\hline & & $\begin{array}{l}\uparrow \text { cytokine and chemokine release, induces } \\
\text { corticosteroid resistance in combination } \\
\text { with IFN } \gamma\end{array}$ \\
\hline & Mast cells & Promotes histamine and tryptase release \\
\hline $\begin{array}{c}\mathrm{SCF}^{97} \\
-\quad \text { constitutive }\end{array}$ & Mast cells & $\begin{array}{l}\text { Growth, differentiation, survival, } \\
\text { chemotaxis. Uncouples } \beta_{2} \text {-adrenoceptor }\end{array}$ \\
\hline \multirow[t]{9}{*}{$\begin{array}{l}\text { NGF } \\
\quad-\quad \text { constitutive }\end{array}$} & B cells & $\begin{array}{l}\text { Differentiation, proliferation, increased Ig } \\
\text { synthesis }\end{array}$ \\
\hline & T cells & Differentiation, proliferation \\
\hline & Eosinophils & Proliferation \\
\hline & Basophils & Activation, mediator release \\
\hline & Neutrophils & Chemotaxis, survival, mediator release \\
\hline & Monocytes/macrophages & Proliferation, mediator release \\
\hline & Fibroblasts & Contraction, migration \\
\hline & Airway smooth muscle & Migration, contraction, proliferation \\
\hline & Mast cells & $\begin{array}{l}\text { Differentiation, survival, activation, } \\
\text { mediator release }\end{array}$ \\
\hline \multirow[t]{5}{*}{$\begin{array}{c}\text { TGF } \beta \\
-\quad \text { constitutive }\end{array}$} & Airway smooth muscle & $\begin{array}{l}\text { Differentiation, } \uparrow \alpha \text {-smooth muscle actin, } \\
\uparrow \text { contraction, activation }\end{array}$ \\
\hline & Fibroblasts & $\begin{array}{l}\text { Myofibroblast differentiation, collagen } \\
\text { secretion, contraction }\end{array}$ \\
\hline & Epithelial cells & Inhibition of proliferation, EMT \\
\hline & Endothelial cells & Increases angiogenesis \\
\hline & Fibrocytes & Promotes differentiation \\
\hline \multirow{3}{*}{$\begin{array}{c}\text { FGF-2 } \\
-\quad \text { FceRI }\end{array}$} & Fibroblasts & Proliferation \\
\hline & Airway smooth muscle & Proliferation \\
\hline & Endothelial cells & Increases angiogenesis \\
\hline $\begin{array}{c}\text { PDGF-A }{ }^{61,376-378} \\
-\quad \text { FceRI }\end{array}$ & Fibroblasts & Proliferation and chemotaxis \\
\hline $\begin{aligned} \text { VEGF } & \text { 379-382 } \\
- & \text { substance } \mathrm{P} \\
- & \text { adenosine } \\
- & \mathrm{PGE}_{2}\end{aligned}$ & Endothelial cells & Angiogenesis \\
\hline \multirow{4}{*}{$\begin{array}{l}\mathrm{IFN \alpha} \\
-\quad \mathrm{TLR} 3\end{array}$} & Natural killer cells & Increases cytotoxicity \\
\hline & Macrophages & Development, maturation \\
\hline & Dendritic cells & $\begin{array}{l}\text { Activation, maturation, increased IFN- } \gamma \\
\text { production }\end{array}$ \\
\hline & T cells & $\begin{array}{l}\text { Increases survival of activated T cells, } \\
\text { promotes Th1 phenotype, inhibits Th2 } \\
\text { phenotype }\end{array}$ \\
\hline \multirow{3}{*}{$\begin{array}{l}\text { TSLP }{ }^{383-385} \\
-\quad \text { Fc\&RI }\end{array}$} & Dendritic cells & Induces Th2 immunity \\
\hline & ILC2 & Activation \\
\hline & Mast cells & Increases IL-5 and -13 expression \\
\hline \multirow{2}{*}{$\begin{array}{l}\text { Amphiregulin }{ }^{386,387} \\
\quad-\quad \text { Fc\&RI }\end{array}$} & Fibroblasts & Induces proliferation \\
\hline & Epithelial cells & Increased mucin gene expression \\
\hline
\end{tabular}


Table 4: Fibrotic responses in animals lacking mast cells or mast cell products

\begin{tabular}{|c|c|c|c|c|c|c|}
\hline $\begin{array}{l}\text { Site of } \\
\text { fibrosis }\end{array}$ & Animals & Model & $\begin{array}{l}\text { Role of } \\
\text { mast } \\
\text { cells/mast } \\
\text { cell } \\
\text { product } \\
\end{array}$ & $\begin{array}{l}\text { Proposed } \\
\text { mechanism }\end{array}$ & $\begin{array}{l}\text { MC } \\
\text { reconst } \\
\text { itution } \\
\text { perfor } \\
\text { med } \\
\end{array}$ & Reference \\
\hline lung & $\mathrm{W} / \mathrm{W}^{\mathrm{v}}$ mice & Bleomycin & $\begin{array}{l}\text { Redundant/ } \\
\text { protective }\end{array}$ & $\begin{array}{l}\text { Higher } \\
\text { hyroxyproline } \\
\text { content in MC- } \\
\text { deficient mice }\end{array}$ & no & 180 \\
\hline lung & Ws/Ws rats & Bleomycin & protective & n.d. ${ }^{\text {a) }}$ & no & 181 \\
\hline lung & $\begin{array}{l}\mathrm{W} / \mathrm{W}^{\mathrm{v}} ; \mathrm{Sl} / \mathrm{Sld} \\
\text { mice }\end{array}$ & allergen & detrimental & $\begin{array}{l}\text { MC-dependent } \\
\text { promotion of } \\
\text { TGF } \beta / \text { collagen } \\
\text { production }\end{array}$ & yes & 182 \\
\hline lung & $\mathrm{W}^{\mathrm{sh}} / \mathrm{W}^{\mathrm{sh}}$ mice & $\begin{array}{l}\text { Allergen (chronic } \\
\text { protocol) }\end{array}$ & detrimental & n.d. & yes & 183 \\
\hline lung & $\mathrm{W}^{\mathrm{sh}} / \mathrm{W}^{\mathrm{sh}}$ mice & Bleomycin & detrimental & $\begin{array}{l}\text { Chymase- } \\
\text { dependent } \\
\text { effects }\end{array}$ & yes & 184 \\
\hline lung & $\mathrm{W} / \mathrm{W}^{\mathrm{v}}$ mice & bleomycin & detrimental & $\begin{array}{l}\text { Profibrotic } \\
\text { histamine; MC- } \\
\text { dependent } \\
\text { renin/Ang II } \\
\text { production }\end{array}$ & yes & 185 \\
\hline lung & $\mathrm{mi} / \mathrm{mi}$ mice & bleomycin & detrimental & $\begin{array}{l}\text { MC-dependent } \\
\text { histamine release }\end{array}$ & no & 186 \\
\hline lung & $\begin{array}{l}\text { Mcpt } 4^{-/-} \\
\text {(chymase- } \\
\text { deficient) } \\
\text { mice }\end{array}$ & bleomycin & detrimental & n.d. & no & 184 \\
\hline skin & $\mathrm{W} / \mathrm{W}^{\mathrm{v}}$ mice & $\begin{array}{l}\text { Tight skin (Tsk) } \\
\text { mice }\end{array}$ & detrimental & n.d. & no & 193 \\
\hline skin & $\mathrm{W} / \mathrm{W}^{\mathrm{v}}$ mice & $\begin{array}{l}\text { biomaterial } \\
\text { implantation }\end{array}$ & detrimental & $\begin{array}{l}\text { MC-dependent } \\
\text { fibrocyte/myofib } \\
\text { roblast responses }\end{array}$ & yes & 194 \\
\hline skin & $\begin{array}{l}\text { Mcpt5-Cre }{ }^{+} \\
\text {mice }\end{array}$ & Bleomycin & redundant & - & no & {$[195$} \\
\hline skin & $\begin{array}{l}\text { Mcpt } 4^{-/-} \\
\text {(chymase- } \\
\text { deficient) } \\
\text { mice }\end{array}$ & spontaneous & protective & $\begin{array}{l}\text { Chymase- } \\
\text { dependent } \\
\text { reduction of } \\
\text { collagen and } \\
\text { fibronectin }\end{array}$ & no & 213,214 \\
\hline liver & Ws/Ws rats & Pig serum-induced & protective & n.d. & no & 181 \\
\hline liver & $\begin{array}{l}\text { Ws/Ws rats; } \\
\text { W/W }{ }^{\mathrm{v}} \text { mice }\end{array}$ & $\begin{array}{l}\mathrm{CCl}_{4} \text { or pig serum- } \\
\text { induced fibrosis }\end{array}$ & protective & n.d. & no & 205 \\
\hline liver & $\mathrm{W}^{\mathrm{sh}} / \mathrm{W}^{\mathrm{sh}}$ mice & bile duct ligation & detrimental & $\begin{array}{l}\text { MC-dependent } \\
\text { TGF } \beta \\
\text { production and } \\
\text { hepatic stellate } \\
\text { cell activation } \\
\end{array}$ & yes & 206 \\
\hline kidney & Ws/Ws rats & $\begin{array}{l}\text { puromycin } \\
\text { aminonucleoside- } \\
\text { nephrosis }\end{array}$ & protective & $\begin{array}{l}\text { MC-dependent } \\
\text { suppression of } \\
\text { TGF } \beta \\
\text { production }\end{array}$ & no & 189 \\
\hline kidney & $\mathrm{Mcpt}^{-/-}$ & immune complex- & detrimental & Effect on pro- & yes & 210 \\
\hline
\end{tabular}




\begin{tabular}{|c|c|c|c|c|c|c|}
\hline & $\begin{array}{l}\text { (chymase- } \\
\text { deficient) } \\
\text { mice }\end{array}$ & $\begin{array}{l}\text { mediated } \\
\text { glomerulonephritis }\end{array}$ & & $\begin{array}{l}\text { inflammatory } \\
\text { cytokines; effect } \\
\text { on Ang II }\end{array}$ & & \\
\hline kidney & $\begin{array}{l}\text { Mcpt4-/- } \\
\text { (chymase- } \\
\text { deficient) } \\
\text { mice }\end{array}$ & $\begin{array}{l}\text { ureteral } \\
\text { obstruction model }\end{array}$ & protective & $\begin{array}{l}\text { Chymase- } \\
\text { dependent } \\
\text { fibronectin } \\
\text { degradation }\end{array}$ & yes & 212 \\
\hline kidney & $\mathrm{W} / \mathrm{W}^{\mathrm{v}}$ mice & $\begin{array}{l}\text { unilateral ureteral } \\
\text { obstruction }\end{array}$ & protective & $\begin{array}{l}\text { higher levels of } \\
\text { TGF } \beta \text { and EMT } \\
\text { markers in MC- } \\
\text { deficient mice }\end{array}$ & yes & 190 \\
\hline kidney & $\mathrm{W} / \mathrm{W}^{\mathrm{v}}$ mice & $\begin{array}{l}\text { unilateral ureteral } \\
\text { obstruction }\end{array}$ & detrimental & $\begin{array}{l}\text { MC expression } \\
\text { of renin, leading } \\
\text { to Ang II } \\
\text { formation }\end{array}$ & no & 188 \\
\hline kidney & $\mathrm{W}^{\text {sh}} / \mathrm{W}^{\text {sh }}$ mice & $\begin{array}{l}\text { unilateral ureteral } \\
\text { obstruction }\end{array}$ & detrimental & $\begin{array}{l}\text { MC enhance the } \\
\text { levels of TGF } \beta \\
\text { and } \alpha \text { SMA }\end{array}$ & yes & 191 \\
\hline cardiac & $\begin{array}{l}\text { WT mice } \\
\text { reconstituted } \\
\text { with bone } \\
\text { marrow from } \\
\text { W/W } / \mathrm{W}^{\mathrm{v}} \text { mice }\end{array}$ & pressure overload & detrimental & $\begin{array}{l}\text { MC-dependent } \\
\text { PDGF-A } \\
\text { expression }\end{array}$ & no & 199 \\
\hline cardiac & $\mathrm{W} / \mathrm{W}^{\mathrm{v}}$ mice & $\begin{array}{l}\text { TNF } \\
\text { overexpression in } \\
\text { heart }\end{array}$ & detrimental & $\begin{array}{l}\text { MC-dependent } \\
\text { TGF } \beta \\
\text { expression; MCs } \\
\text { targets for TNF }\end{array}$ & no & 200 \\
\hline
\end{tabular}

\footnotetext{
a) n.d., not determined
} 
Table 5: Summary of pharmacological approaches used for targeting mast cells and mast cell products in animal models of fibrosis

\begin{tabular}{|c|c|c|c|c|}
\hline Compound & $\begin{array}{l}\text { Type of } \\
\text { compound }\end{array}$ & Model & $\begin{array}{l}\text { Outcome/proposed } \\
\text { mechanism }\end{array}$ & Reference \\
\hline Nedocromil & $\begin{array}{l}\text { Mast cell } \\
\text { stabiliser }\end{array}$ & $\begin{array}{l}2,4,6,- \\
\text { trinitrobenzene } \\
\text { sulfonic acid- } \\
\text { induced colitis } \\
\text { (rats) }\end{array}$ & Reduced fibrosis & 242 \\
\hline Nedocromil & $\begin{array}{l}\text { Mast cell } \\
\text { stabiliser }\end{array}$ & $\begin{array}{l}\text { left ventricular } \\
\text { fibrosis (rats) }\end{array}$ & Reduced fibrosis & 243 \\
\hline Nedocromil & $\begin{array}{l}\text { Mast cell } \\
\text { stabiliser }\end{array}$ & $\begin{array}{l}\text { cardiac fibrosis } \\
\text { after transverse } \\
\text { aortic constriction } \\
\text { (rats) }\end{array}$ & Reduced fibrosis & 240 \\
\hline Tranilast & $\begin{array}{l}\text { Mast cell } \\
\text { stabiliser }\end{array}$ & $\begin{array}{l}\text { Bleomycin-induced } \\
\text { pulmonary fibrosis } \\
\text { (mice) }\end{array}$ & $\begin{array}{l}\text { Reduced fibrosis (equal } \\
\text { effects in MC-sufficient } \\
\text { and-deficient mice) }\end{array}$ & 180 \\
\hline Tranilast & $\begin{array}{l}\text { Mast cell } \\
\text { stabiliser }\end{array}$ & $\begin{array}{l}\text { chronic renal } \\
\text { failure (rats) }\end{array}$ & No effect & 244 \\
\hline $\begin{array}{l}\text { Sodium } \\
\text { cromoglycate }\end{array}$ & $\begin{array}{l}\text { Mast cell } \\
\text { stabiliser }\end{array}$ & $\begin{array}{l}\text { autoimmune } \\
\text { myocarditis (rats) }\end{array}$ & Reduced fibrosis & 197 \\
\hline $\begin{array}{l}\text { Sodium } \\
\text { cromoglycate }\end{array}$ & $\begin{array}{l}\text { Mast cell } \\
\text { stabiliser }\end{array}$ & $\begin{array}{l}\text { atrial fibrosis } \\
\text { occurring after } \\
\text { pressure overload } \\
\text { (mice) }\end{array}$ & Reduced fibrosis & 199 \\
\hline $\begin{array}{l}\text { Sodium } \\
\text { cromoglycate }\end{array}$ & $\begin{array}{l}\text { Mast cell } \\
\text { stabiliser }\end{array}$ & $\begin{array}{l}\text { implantation of } \\
\text { biomaterials (mice) }\end{array}$ & Reduced fibrosis & 194 \\
\hline $\begin{array}{l}\text { Sodium } \\
\text { cromoglycate }\end{array}$ & $\begin{array}{l}\text { Mast cell } \\
\text { stabiliser }\end{array}$ & $\begin{array}{l}\text { unilateral ureteral } \\
\text { obstruction model } \\
\text { (mice, rats) }\end{array}$ & Reduced fibrosis & 188,191 \\
\hline $\begin{array}{l}\text { Sodium } \\
\text { cromoglycate }\end{array}$ & $\begin{array}{l}\text { Mast cell } \\
\text { stabiliser }\end{array}$ & $\begin{array}{l}\text { liver fibrosis in } \\
\text { multidrug } \\
\text { resistance } 2 \\
\text { knockout mice } \\
\text { (mice) }\end{array}$ & Reduced fibrosis & 245 \\
\hline SUN-C8077 & $\begin{array}{l}\text { Chymase } \\
\text { inhibitor }\end{array}$ & $\begin{array}{l}\text { bleomycin-induced } \\
\text { lung fibrosis (mice) }\end{array}$ & Reduced fibrosis & 227 \\
\hline $\begin{array}{l}\text { BCEAB (4-[1- } \\
\text { ([bis-(4-methyl- } \\
\text { phenyl)-methyl]- } \\
\text { carbamoyl)3-(2- } \\
\text { ethoxy-benzyl)-4- } \\
\text { oxo-azetidin e-2- } \\
\text { yloxy]-benzoic } \\
\text { acid) }\end{array}$ & $\begin{array}{l}\text { Chymase } \\
\text { inhibitor }\end{array}$ & $\begin{array}{l}\text { bleomycin-induced } \\
\text { lung fibrosis } \\
\text { (hamsters) }\end{array}$ & $\begin{array}{l}\text { Reduced fibrosis; decrease } \\
\text { in TGF } \beta \text { and MMP2; } \\
\text { decreased effects of ET-1 }\end{array}$ & 228 \\
\hline TY-51469 & $\begin{array}{l}\text { Chymase } \\
\text { inhibitor }\end{array}$ & $\begin{array}{l}\text { liver fibrosis after } \\
\text { feeding on a } \\
\text { methionine- and } \\
\text { choline-deficient } \\
\text { diet (hamsters) }\end{array}$ & $\begin{array}{l}\text { Reduced fibrosis; } \\
\text { attenuated induction of } \\
\text { Ang II and collagen } \\
\text { expression }\end{array}$ & 231 \\
\hline $\begin{array}{l}\text { TEI-E00548; TEI- } \\
\text { F0080 }\end{array}$ & $\begin{array}{l}\text { Chymase } \\
\text { inhibitors }\end{array}$ & $\begin{array}{l}\text { cardiac fibrosis in } \\
\text { diabetic hamsters }\end{array}$ & $\begin{array}{l}\text { Reduced fibrosis; } \\
\text { Reduced Ang II } \\
\text { production; attenuated } \\
\text { NOX4-associated } \\
\text { oxidative stress }\end{array}$ & 232 \\
\hline
\end{tabular}




\begin{tabular}{|c|c|c|c|c|}
\hline TY51469 & $\begin{array}{l}\text { Chymase } \\
\text { inhibitor }\end{array}$ & $\begin{array}{l}\text { cardiac fibrosis } \\
\text { after ischemia } \\
\text { reperfusion injury } \\
\text { (pigs) }\end{array}$ & $\begin{array}{l}\text { Reduced fibrosis; reduced } \\
\text { MMP9 activation; reduced } \\
\text { inflammation }\end{array}$ & 233 \\
\hline TY-51469 & $\begin{array}{l}\text { Chymase } \\
\text { inhibitor }\end{array}$ & $\begin{array}{l}\text { silica induced } \\
\text { pulmonary fibrosis } \\
\text { (mice) }\end{array}$ & $\begin{array}{l}\text { Reduced fibrosis; reduced } \\
\text { neutrophil accumulation; } \\
\text { reduced TGF } \beta \text { levels }\end{array}$ & 234 \\
\hline TY-51469 & $\begin{array}{l}\text { Chymase } \\
\text { inhibitor }\end{array}$ & $\begin{array}{l}\mathrm{CCl}_{4} \text {-induced liver } \\
\text { fibrosis (hamsters) }\end{array}$ & $\begin{array}{l}\text { Reduced fibrosis; reduced } \\
\text { Ang II formation; reduced } \\
\text { QSMA positivity }\end{array}$ & {$[235$} \\
\hline $\begin{array}{l}\text { 4-[1-(4-methyl- } \\
\text { benzo[b]thiophen- } \\
\text { 3-ylmethyl)-1H- } \\
\text { benzimidazol-2- } \\
\text { ylsulfanyl]-butyric } \\
\text { acid }\end{array}$ & $\begin{array}{l}\text { Chymase } \\
\text { inhibitor }\end{array}$ & $\begin{array}{l}\text { tubulointerstitial } \\
\text { fibrosis in } \\
\text { obstructed kidneys } \\
\text { (hamsters) }\end{array}$ & $\begin{array}{l}\text { Reduced fibrosis; reduced } \\
\text { Ang II, TGF } \beta, \alpha \text { SMA }\end{array}$ & 236 \\
\hline NK3201 & $\begin{array}{l}\text { Chymase } \\
\text { inhibitor }\end{array}$ & $\begin{array}{l}\text { cardiac fibrosis } \\
\text { after ligation of the } \\
\text { left anterior } \\
\text { descending } \\
\text { coronary artery } \\
\text { (rats) }\end{array}$ & Reduced fibrosis & 237 \\
\hline NK3201 & $\begin{array}{l}\text { Chymase } \\
\text { inhibitor }\end{array}$ & $\begin{array}{l}\text { bleomycin-induced } \\
\text { pulmonary fibrosis } \\
\text { (hamsters) }\end{array}$ & Reduced fibrosis & 229 \\
\hline $\begin{array}{l}\text { BCEAB (4-[1- } \\
\text { ([bis-(4-methyl- } \\
\text { phenyl)-methyl]- } \\
\text { carbamoyl)3-(2- } \\
\text { ethoxy-benzyl)-4- } \\
\text { oxo-azetidin e-2- } \\
\text { yloxy]-benzoic } \\
\text { acid) }\end{array}$ & $\begin{array}{l}\text { Chymase } \\
\text { inhibitor }\end{array}$ & $\begin{array}{l}\text { cardiac fibrosis in } \\
\text { cardiomyopathy } \\
\text { (hamsters) }\end{array}$ & Reduced fibrosis & 238 \\
\hline SUNC8257 & $\begin{array}{l}\text { Chymase } \\
\text { inhibitor }\end{array}$ & $\begin{array}{l}\text { cardiac fibrosis } \\
\text { after tachycardia } \\
\text { (dogs) }\end{array}$ & $\begin{array}{l}\text { Reduced fibrosis; reduced } \\
\text { Ang II levels; redced } \\
\text { TGF } \beta \text { mRNA }\end{array}$ & 239 \\
\hline $\begin{array}{l}\text { Nafamostat } \\
\text { mesylate }\end{array}$ & Tryptase inhibitor & $\begin{array}{l}\text { cardiac fibrosis } \\
\text { after transverse } \\
\text { aortic constriction } \\
\text { (rats) }\end{array}$ & Reduced fibrosis & 240 \\
\hline APC-366 & Tryptase inhibitor & $\begin{array}{l}\text { bile duct ligation- } \\
\text { induced liver } \\
\text { fibrosis (rats) }\end{array}$ & Reduced fibrosis & 241 \\
\hline
\end{tabular}




\section{FIGURE LEGENDS}

Figure 1. Mast cells immunostained for tryptase in the fibrotic lung of a patient with IPF, demonstrating partial loss of secretory granules.

Figure 2. Potential mechanisms of mast cell activation. Receptors capable of modulating human mast cell activation. Human MCs express a broad range of receptors, allowing them to respond to a diverse range of stimuli, including via IgE-independent mechanisms.

Downstream pathways of each individual receptor are not fully understood, but ultimately lead to MC degranulation, gene transcription, arachidonic acid metabolism and cytokine production. Among the well-known signalling pathways are the PLC $\gamma$ and PI3K pathways which induce an increase in intracellular $\mathrm{Ca}^{2+}$ mobilization and $\mathrm{Ca}^{2+}$ influx. PAF, platelet activatingfactor; PI3K, phosphoinositide 3-kinase; PLC $\gamma$, phospholipase C $\gamma$; IP3, inositol1,4,5-triphosphate; TLR, toll-like receptor; LPS, lipopolysaccharide; PGN, peptidoglycan; MBP-1, major basic protein-1; FcR, Fc receptor; CRH, corticotropin-releasing hormone; CRH-R, CRH receptor; PAR, protease-activated receptor.

Figure 3. A summary of the potential pro-fibrotic interactions between mast cells and fibroblasts. Dotted arrows $=$ stimuli acting on MCs; solid arrows $=$ MC-derived stimuli or effects; red text $=$ structural cell-derived cytokines .

Figure 4. Potential points for therapeutic intervention aimed at inhibiting mast cell function.

Figure 5. The pro-fibrotic versus anti-fibrotic role of mast cells. 